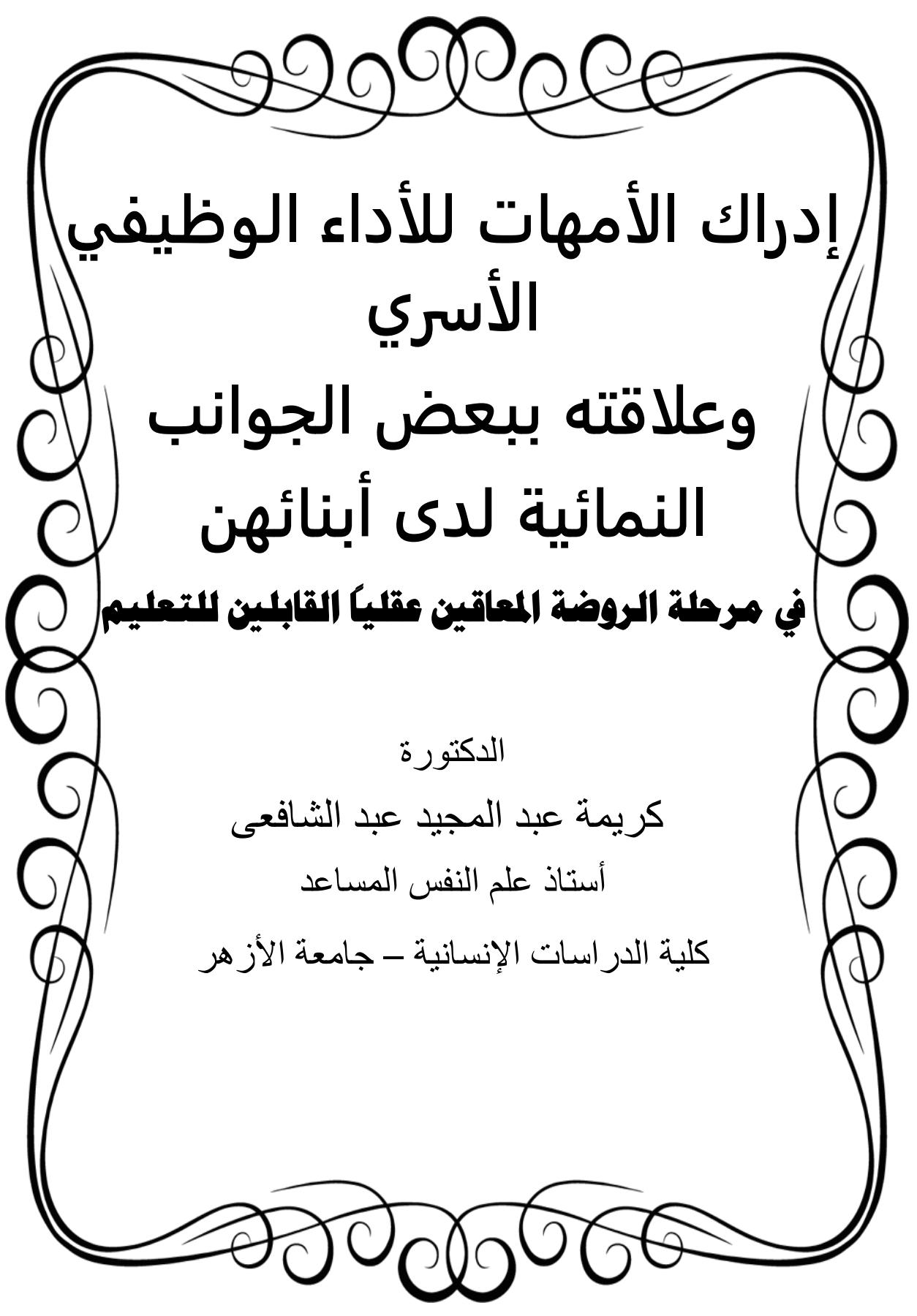


28

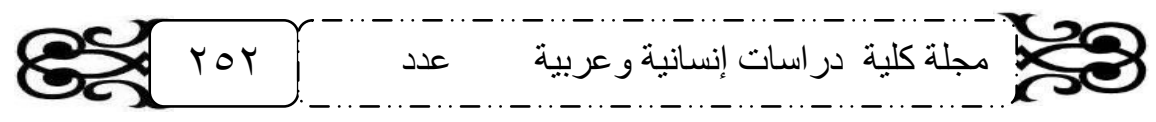


28 إدراك الأمهات للأداء

المستخلص: هدف البحث الكثف عن الاداء الـوظيفي الاسـري

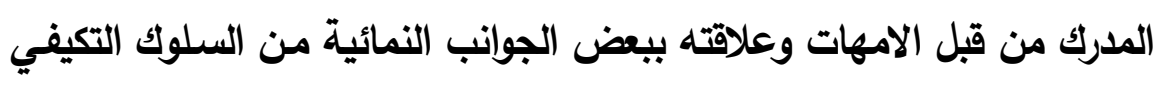

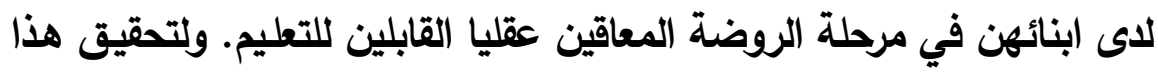

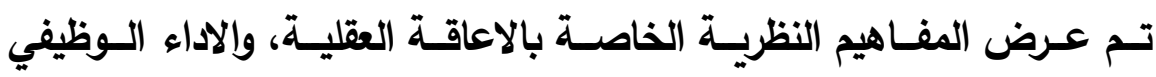

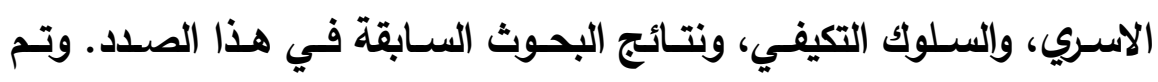

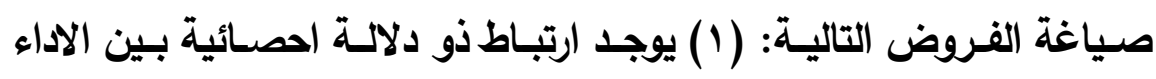

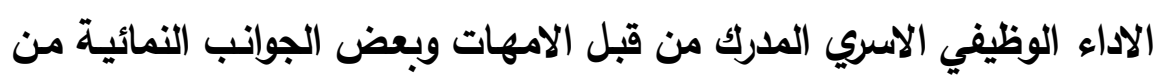

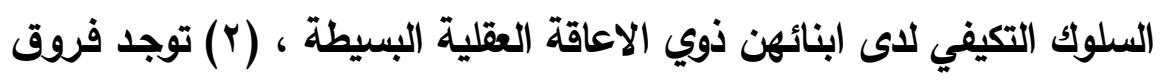

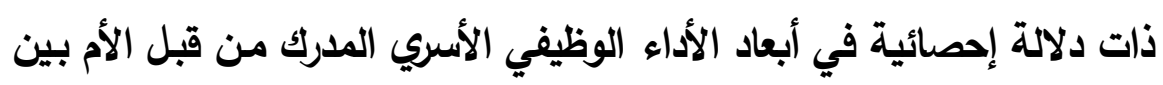

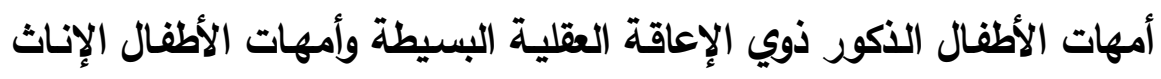

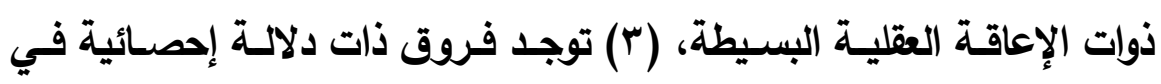

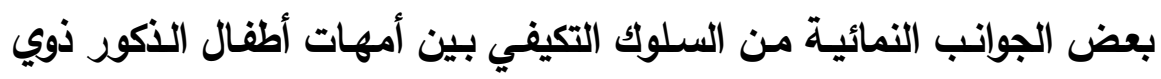

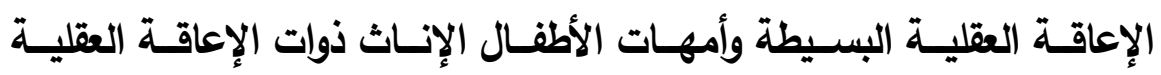

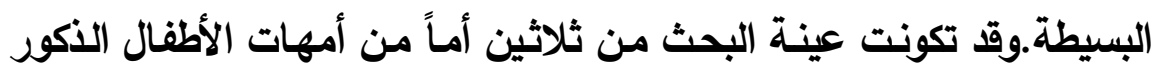

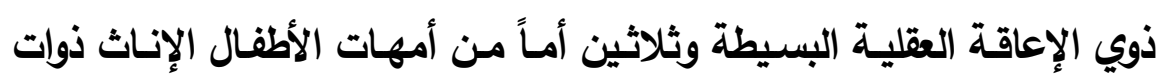

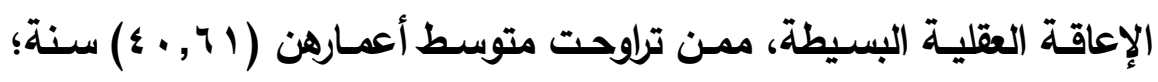

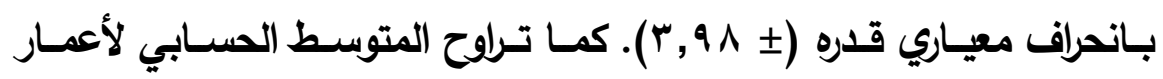

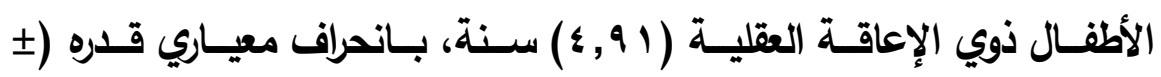

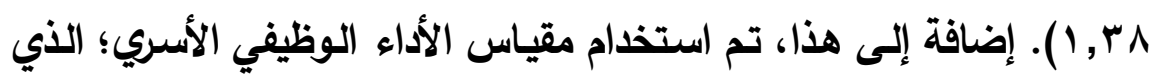

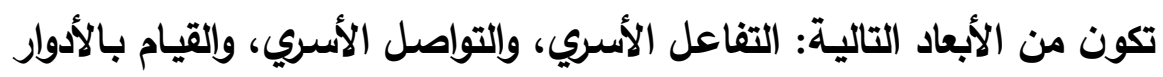

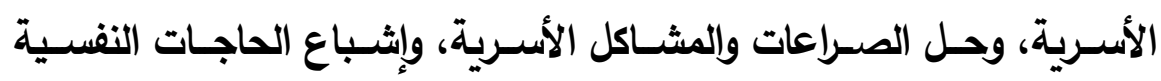

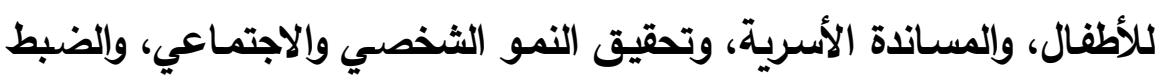
الأسري، ومقياس الجانب النمائي من السلوك التكيفي؛ الني تكون من الأبعاد

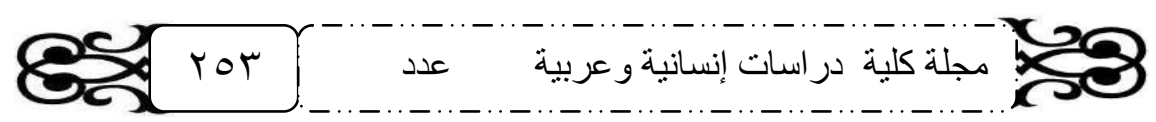


28 إدراك الأمهات للأداء

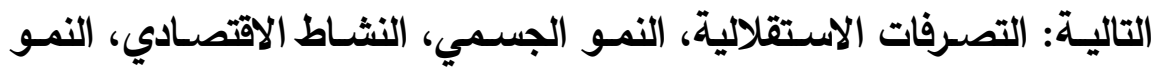

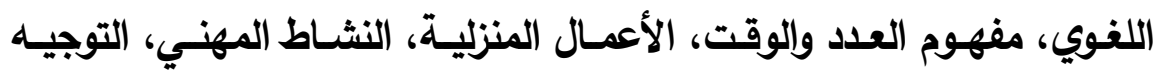

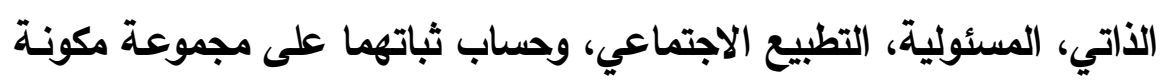

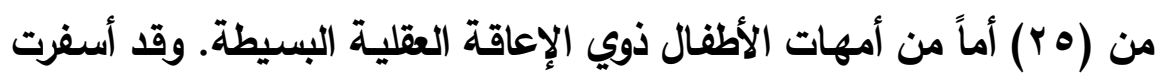

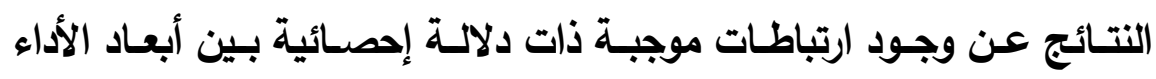

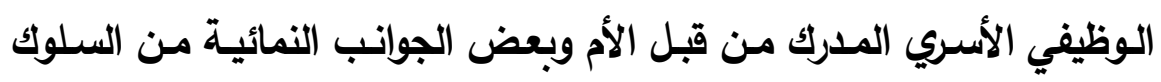

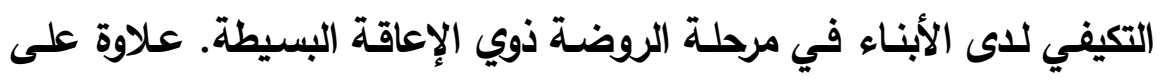

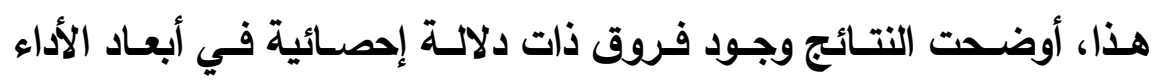

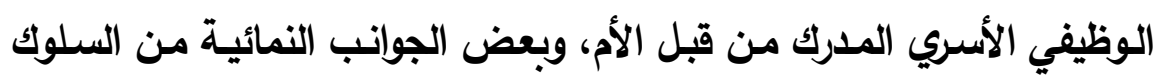

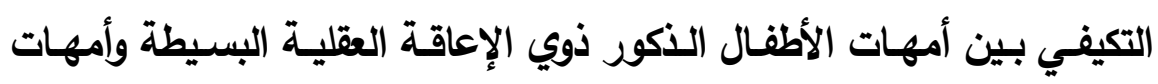

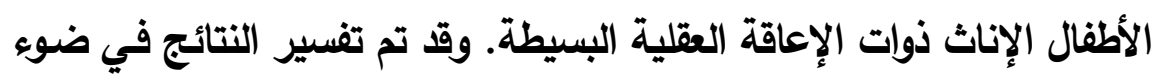

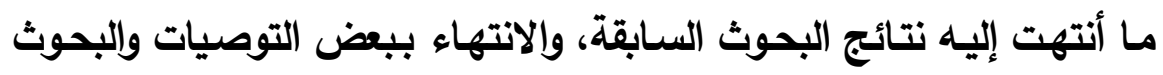
المقترحة. 
28

\section{مقدمة البهش:}

إن الأسـرة بمــا تلعبـه مـن أدوار مختلفـة فـي رعايـة أفرادهـا وتثـكيل

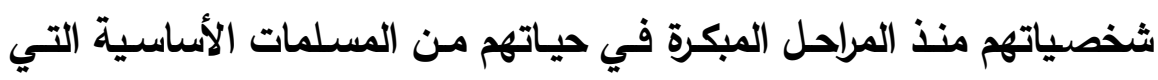

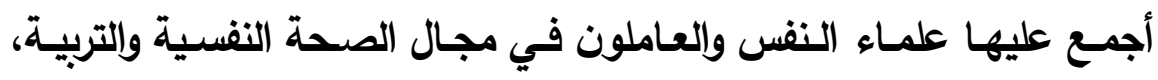
فالأسرة هي مسرح التفاعل الذي يتم فيه النمو والتعليم بكافة أشكالها، إلى الـى

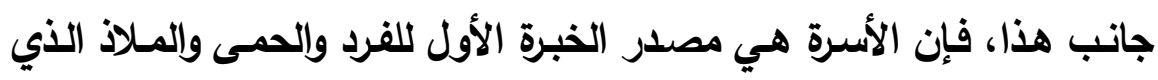
يلجأ إليه.

وقد ظهر حديثاً الاهتمام بدراسـة الدور الوظيفي الأسري المتمثل في

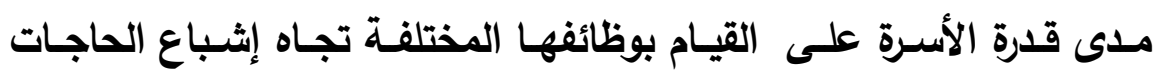

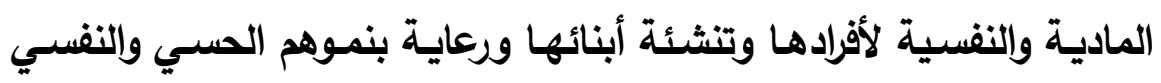

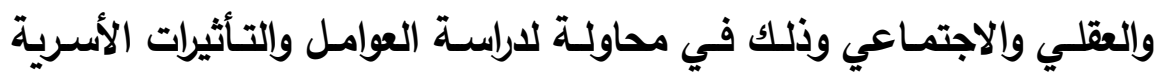

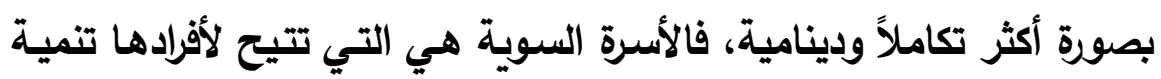
قدراتهم وإثباع حاجاتهم بطريقة صحيحة وبناءة (عبد السلام، ؛ . . ب).

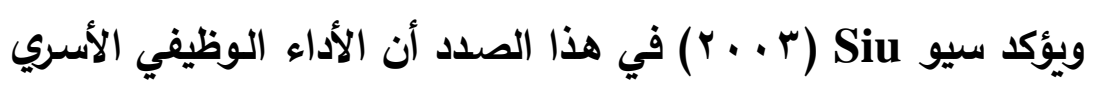

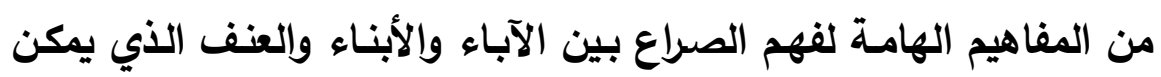

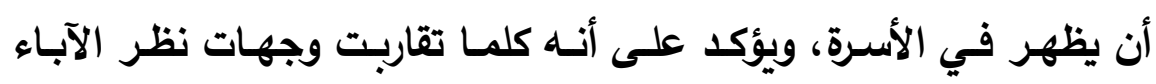

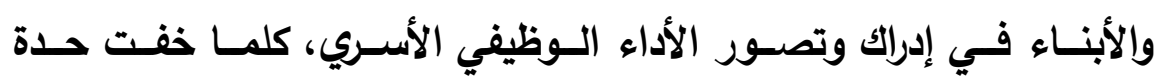
الصراعات بينهم وازداد الترابط داخل الأسرة.

ويطرح لنا كل من بترسون وجرين Petrson \& Green (9 9 9 (1) ) الأدوار الأساسية للأسرة فيما يلي: 1- إدارة النسق الأسري، والقيام بـه من خـلال القيادة الرشيدة وتـبير

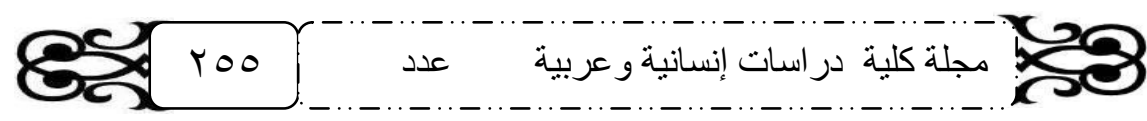




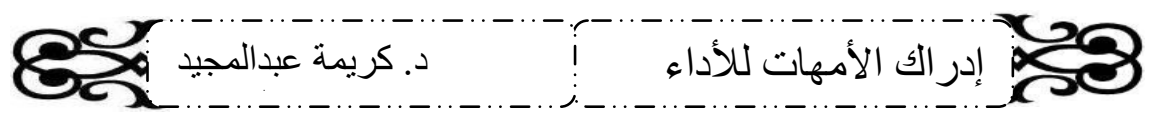

المـوارد الماليـة وتهـذيب سـلوك الأفراد وتأكيــ أنمـاط السـلوك المرغوبـة والإيجابية لايههم.

r - توفير الاحتياجات الأساسية من ملبس وحماية ومأمن لجميع أفراد

الأسرة.

r- التنشئة السوية والمسـاندة وتوفير الراحة واللدفء النفسي لجميع

ع - تنمية المهارات الحياتية والاجتماعية والتربوية والانفعالية والجسمية

لأفرادها.

وبسبب التغيرات الجذرية البنائية التي ظهرت في الأسرة بثكلها الجديد

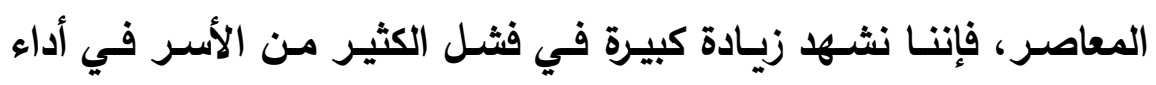

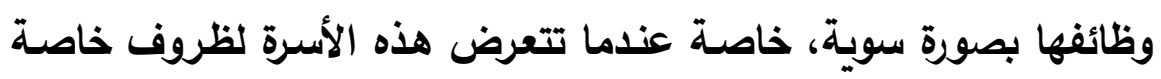
أو ضاغطة، مثل وجود طفل معاق عقلياً.

إضافة إلى أن وجود طفل معاق عقلياً في الأسرة، يؤثر عليها وعلى

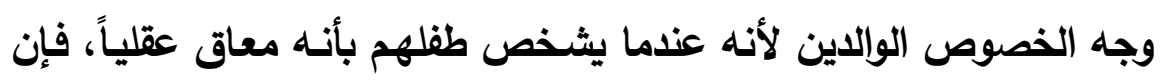

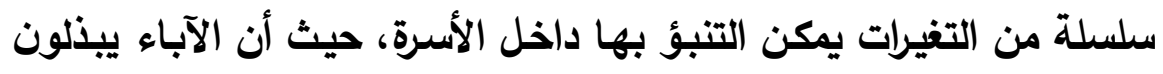

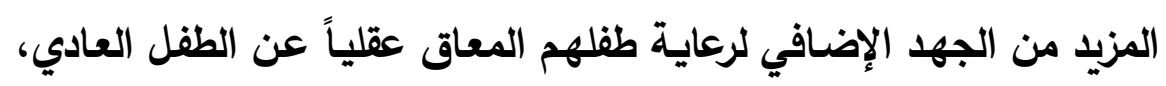

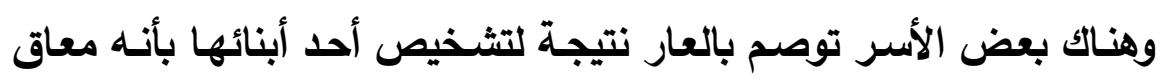
عقلياً، وإلى جانب ذلك نجد أن آباء هؤلاء الأطفال يبقون في منازلهم لفترات التهات

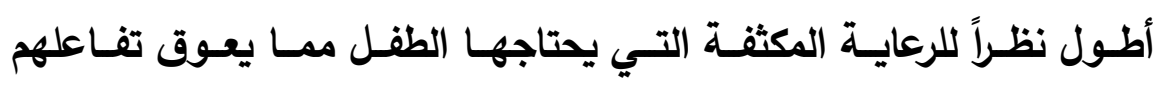

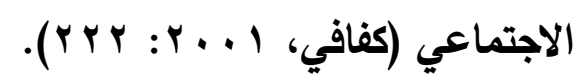

وقد أوضـح جونسـون Jonson (991 ا: بـ ؛ ؛) أن الطفل المعـاق

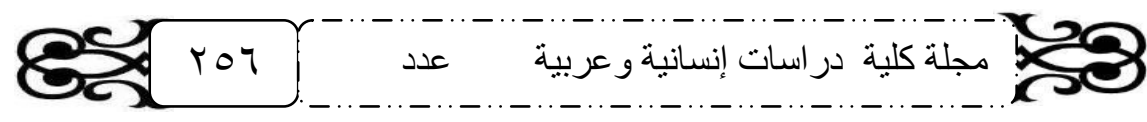




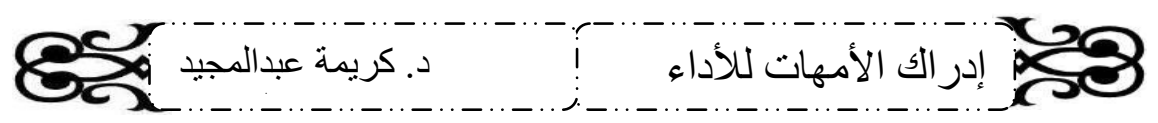
عقلياً يؤثر في الأسرة؛ حيث يؤدي إلى انخفاض مستوى أداء الوالدين

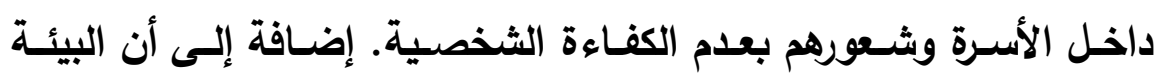

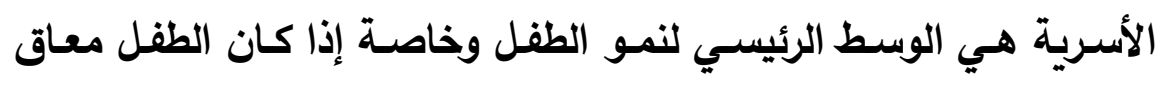

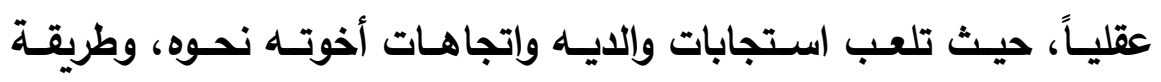
معاملتهر لـه، هي التـي تثكل صورته عن ذاتـه وتحدد مستوى تكيفـه إيجابياً أم سلبياً.

ومن ثم، فإن هناك علاقة تبادلية بين الأداء الوظيفي الأسري والسلوك

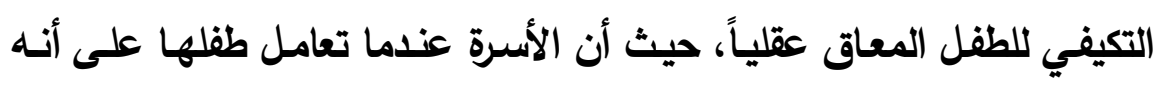

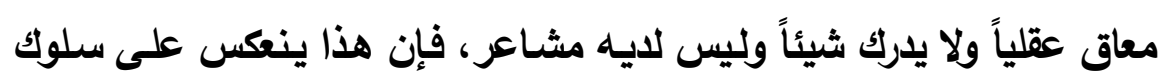

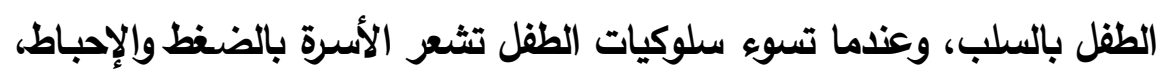

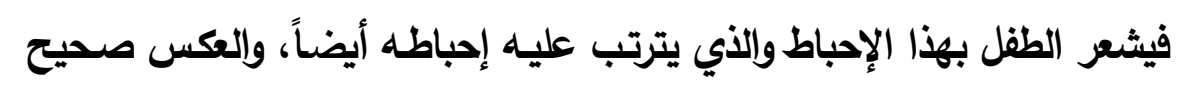

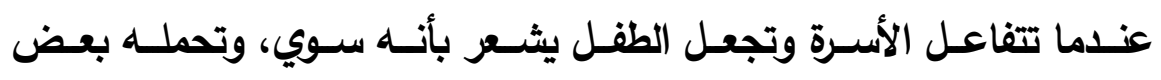

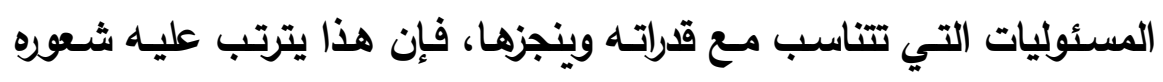
بالثقة بالنفس، وبأنه شخص إيجابي، ويحاول أن يتحسن ليتلقى من الأسرة

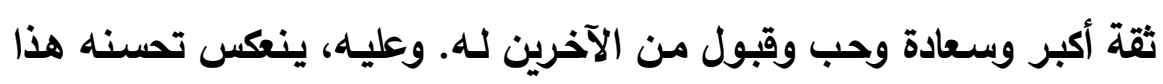
على تحسن تماسك الأسرة وإلعلاقات بينها.

ونظراً لقلة البحوث التي حاولت الكثف عن الأداء الوظيفي الأسري كما

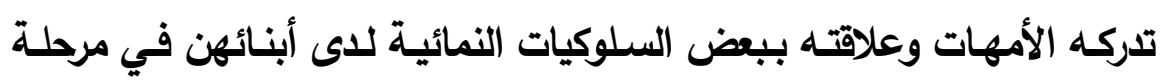

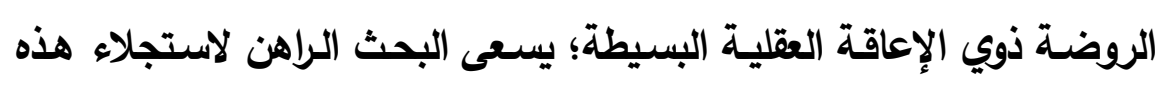
العلاقة بين هذين المتغيرين. 
28

\section{مشكلة البمثث:}

تعاني بعض الأسر على الجانب النفسي والاجتمـاعي من وجود طفل

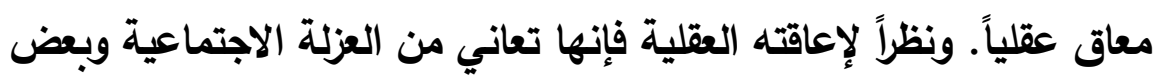

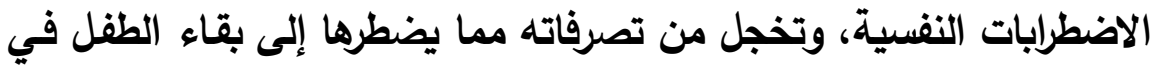
المنزل معظم الوقت مما يؤدي هذا إلى حرمانهه من التفاعل ميع الآخرين

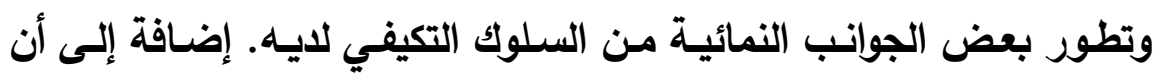

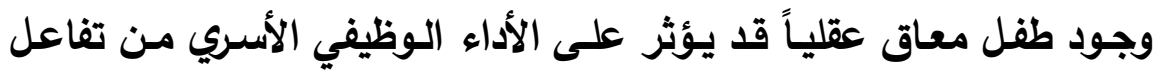

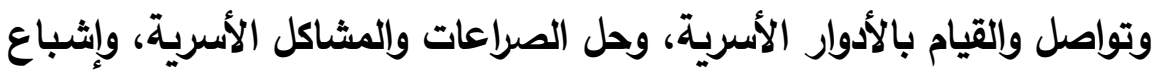

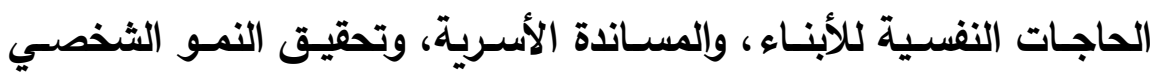

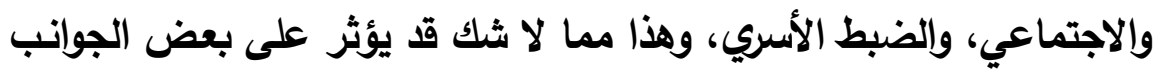
النمائية للسلوك التكيفي لاعى الطفل ذي الإعاقة العقلية.

كما تبين من خلال مراجعة البحوث السـابقة في هذا الصداد أن هناك

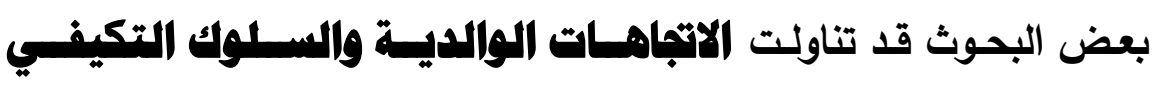

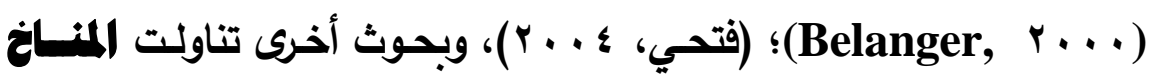

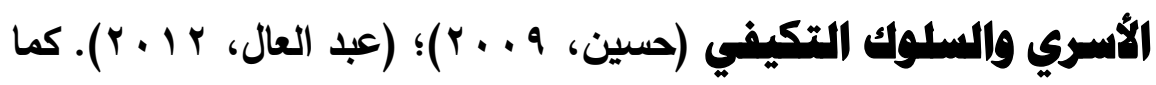
تبين وجود قلة من البحوث التي تناولت الأداء الوظيفي الأسري وعلاقته

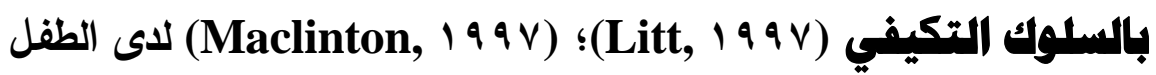
ذي الإعاقة العقلية. وعليـه تبين مـن خـلال مفـاهيم الاتجاهـات الوالديـة، والمنــاخ الأسـري،

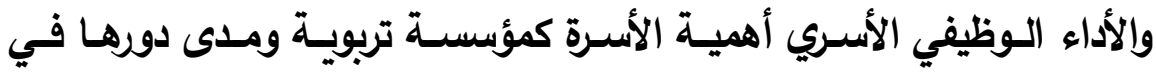

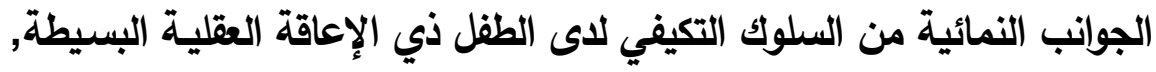

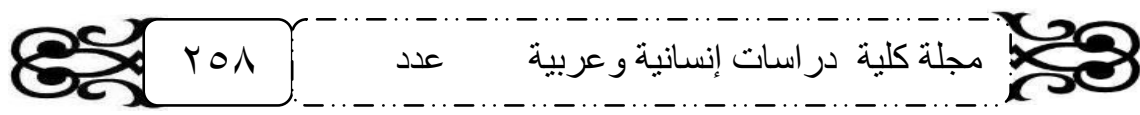


28

وعليه، ترى الباحثة الحالية في ضوء مـا تقدم أهمية الأداء الوظيفي الأسري

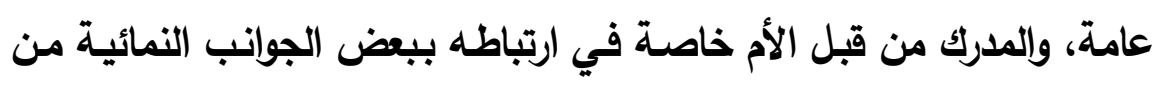

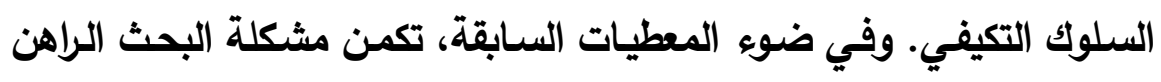

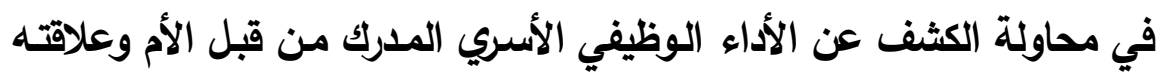

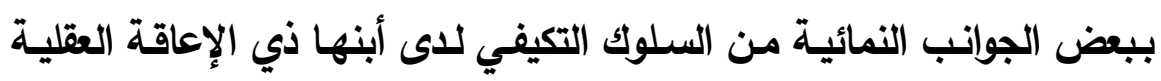

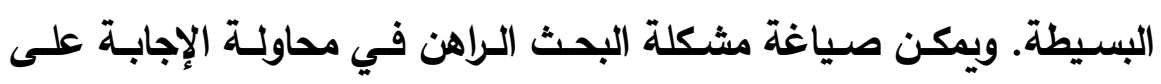
التساؤلات التالية: - التينة وبكن

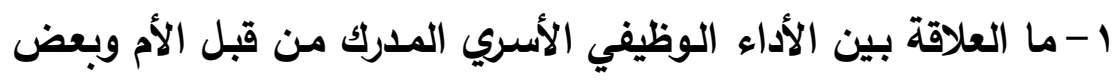

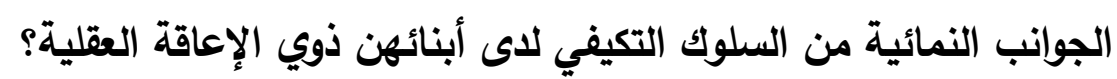
r - ما الفروق في أبعاد الأداء الوظيفي الأسري المدرك من قبل الأم بين أمهات الأطفـال الـكور ذوي الإعاقـة العقليـة البسـيطة وأمهات الأطفـال الإناث ذوات الإعاقة العقلية البسيطة؟ الإل الاعكاته r- مـا الفروق في بعض الجوانب النمائيـة من السلوك التكيفي بين أمهـات الأطفـال الـذكور ذوي الإعاقـة العقليـة البسـيطة وأمهات الأطفـال الإناث ذوات الإعاقة العقلية البسيطة؟ الإل الاعكاقة

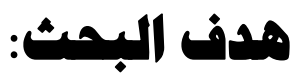

هاف البحث الراهن الكثف عن الأداء الوظيفي الأسري المدرك من قبل

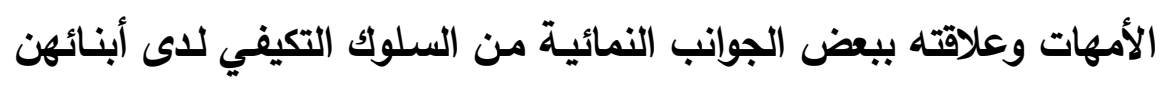
في مرحلة الروضة المعاقين عقلياً القابلين للتعليم. 


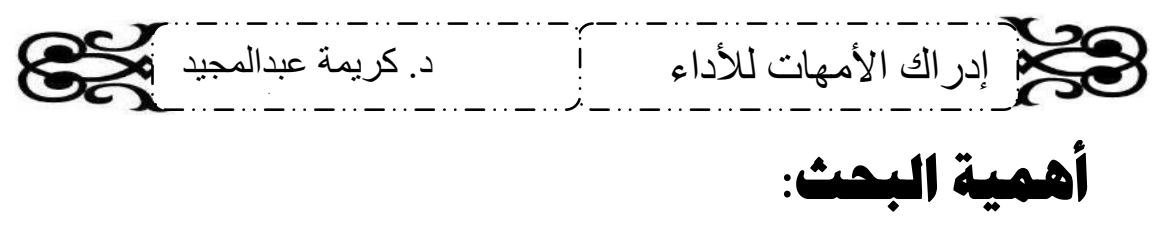

يمكن تحديد أهمية البحث العلمية والعملية في النقاط التالية: -قلـة البحوث التي أجريـت على صسيد المجتمعات العببيـة عامـة،

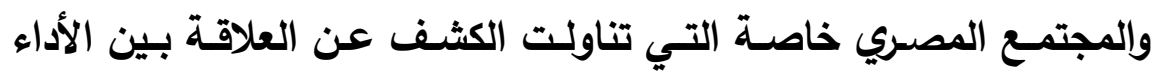

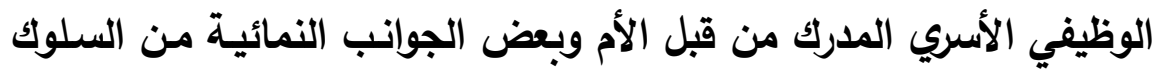
التكيفي لاى أبنها ذي الإعاقة العقلية البسيطة. - أن النتائج التي يسفر عنها البحث الراهن سوف يساعد العاملين في

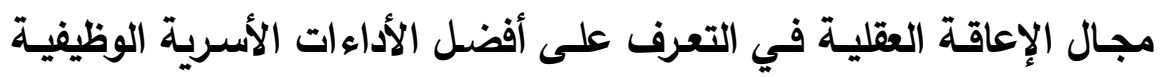

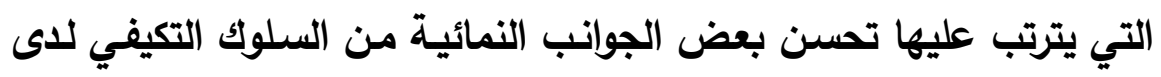
الطفل ذي الإعاقة العقلية البسيطة.

\section{هدود البمث:}

يتحدد البحث بالعينة المستخدمة المكونـة من ثلاثين أماً من أمهات

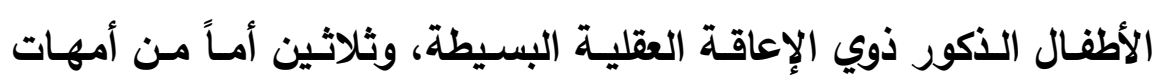

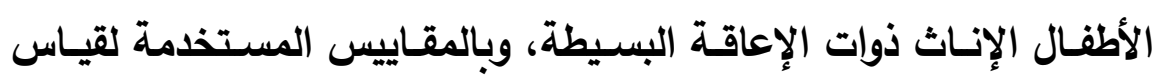

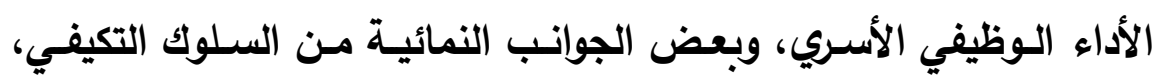
وبالأساليب الإحصائية المناسبة.

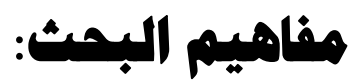

يمكن عرض مفاهيم البحث على النحو التالي:

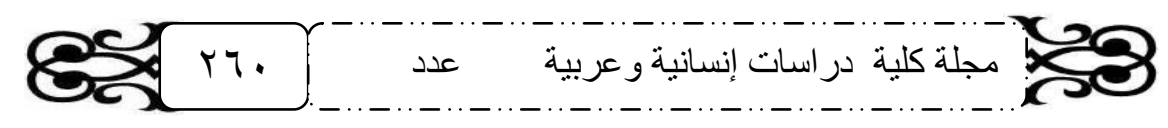




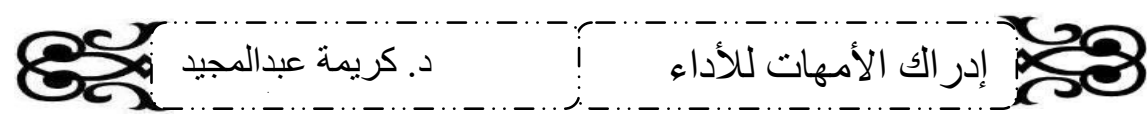

\section{أولأ: الإعاقة العقاية:}

تعرّف الإعاقـة العقليـة بأنها: حالـة مـن توقفـ النمـاء العقلـي أو عدم اكتماله، تتصف بثكل خاص باختلالات في المهارات تظهر أثناء طور النماءء ،

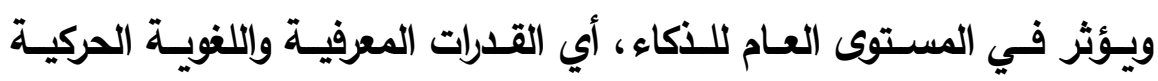
والاجتماعية. وقد يحثث التأخر مع أو بدون اضطراب نفسي أو أو جسمي آخر .

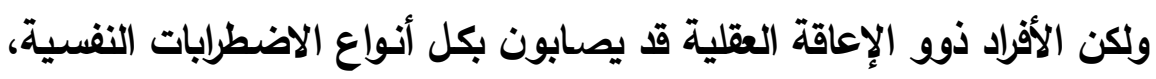

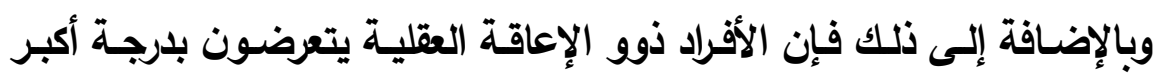

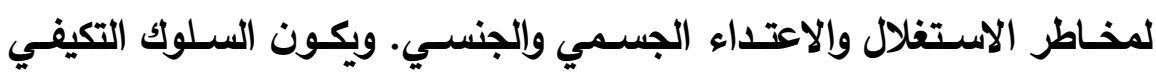

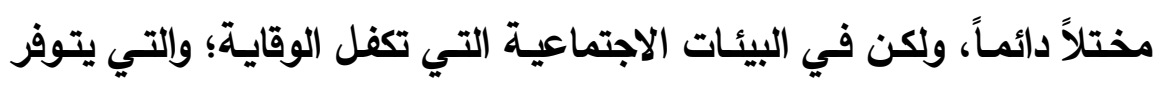

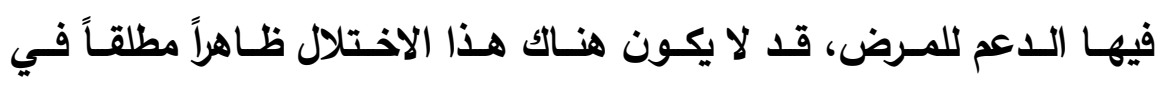

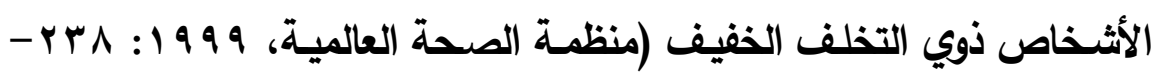
. r r a

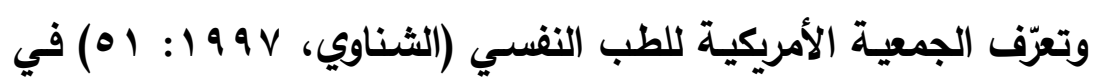

الطبعة الرابعة من دليل تثخيص الاضطرابات النفسية والاجتماعية الإعاقة العقلية بأنها: انخفاض ملحوظ دون المستوى العادي في الوظائف العقلية

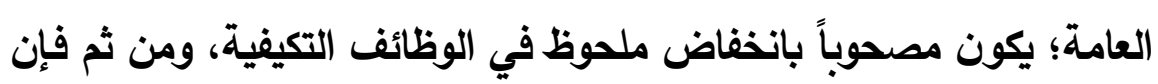

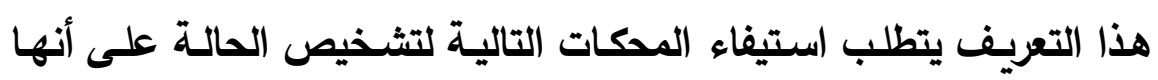
إعاقة عقلية:

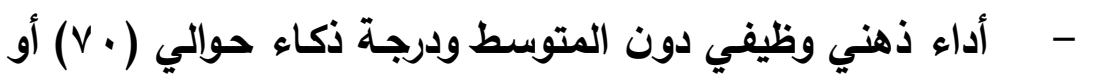
أقل على اختبار ذكاء يطبق فردياً.

- جوانب قصور مصاحبة للأداء التكيفي الراهن في أثنين على

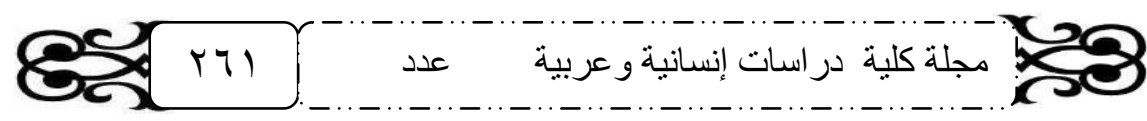




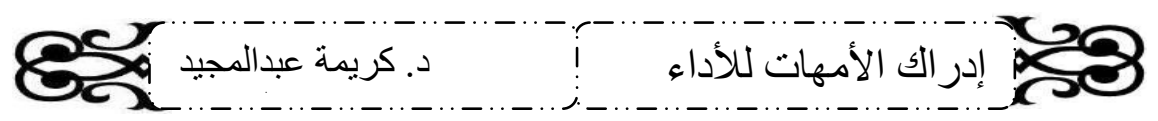

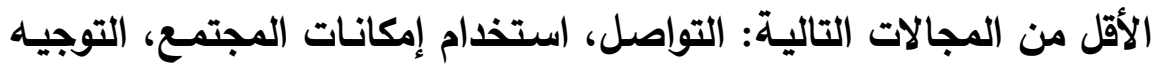

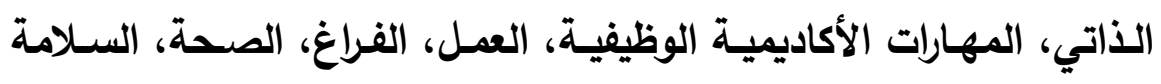
والتكيف مع متطلبات المواقف والحياة الاجتماعية.

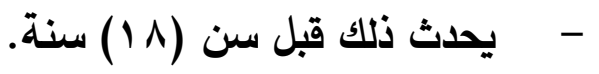

كما تمثل الإعاقة العقلية كما أشارت إلى ذلك الجمعية الأمريكية للتخلف

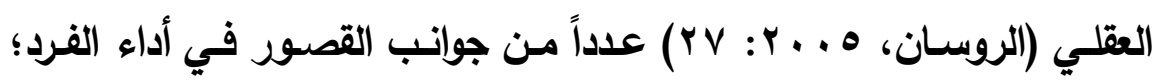

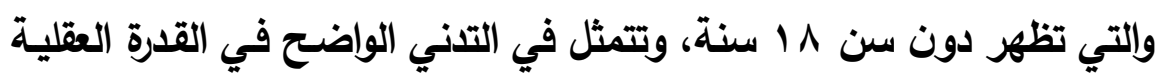
عن متوسط الاكاء • V درجة، وقصور واضح في اثنتين أو أكثر من مظاهر

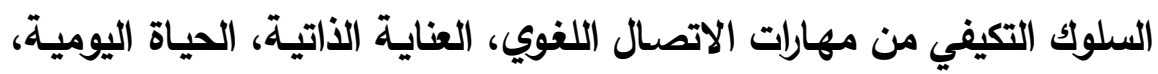

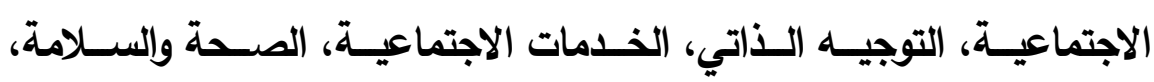

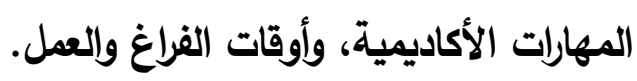

إلى جانب هذا، ينص التعريف الفيدرالي للتخلف العقلي بأنه: القصور

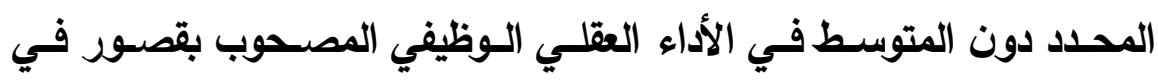

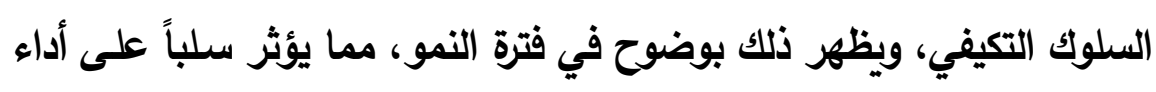

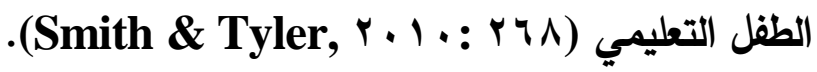
إضافة إلى هذا، توجد تعريفات عربية للإعاقة العقلية، تعبر في جوهرها

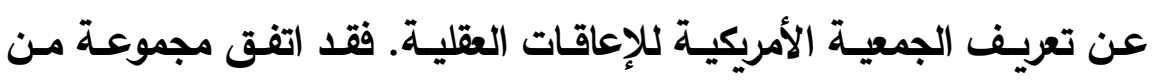

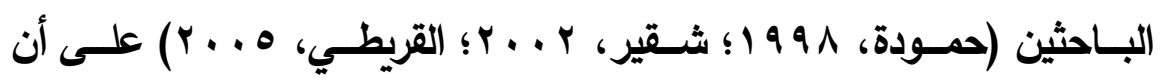

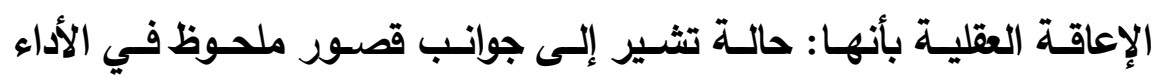

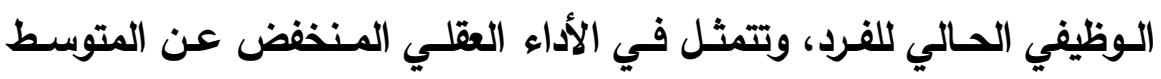

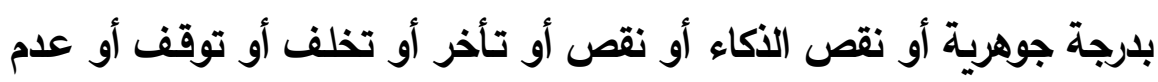

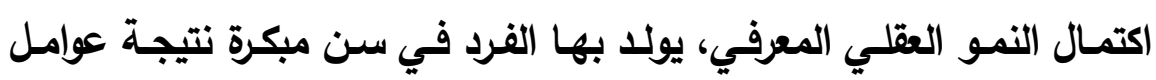
28 
28 إدراك الأمهات للأداء

وراثية أو مكتسبة، وحدد معامل الذكاء V كدد أعلى لذوي الإعاقة العقلية،

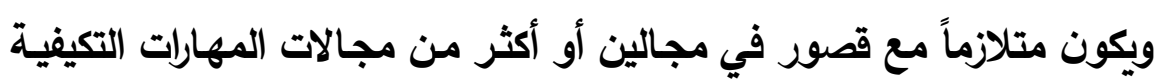

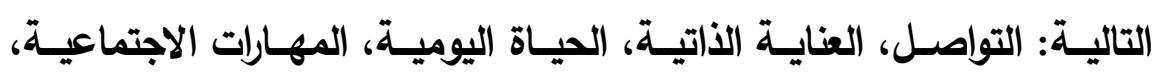

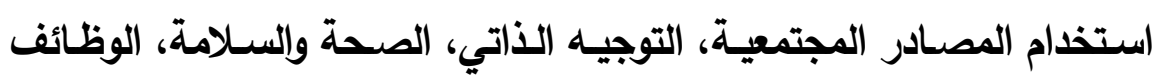

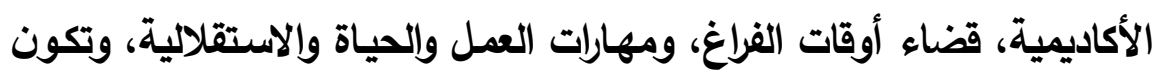

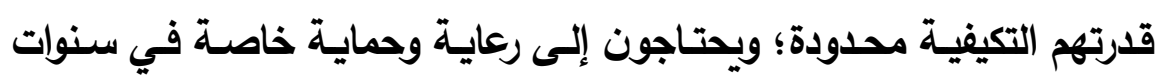

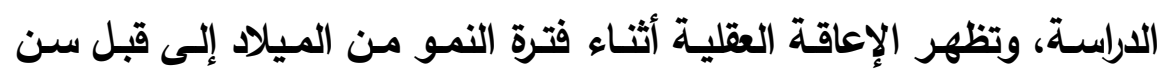
الثامنة عشرة.

وقد تم تصنيف حالات الإعاقة العقلية إلى أكثر من تصنيف. ومن أهم التصنيفات التي تواترت الإثارة إليها في الأدبيات النفسية الأجنبية والعربية الألية

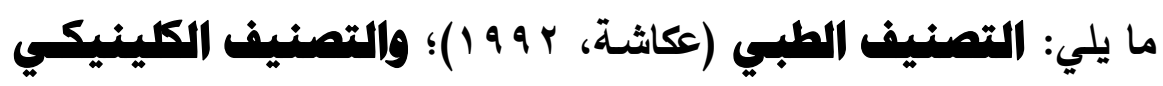

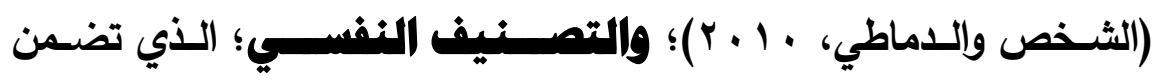

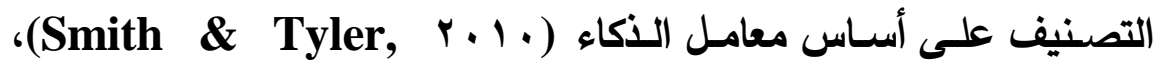
والتصنيف التربوي، والذي تبنته الباحثة في بحثها الراهن، وهو يتضمن

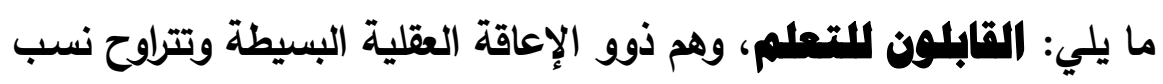

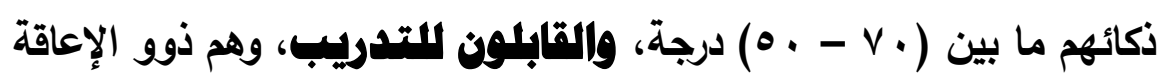

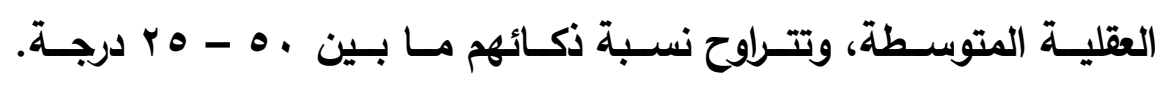

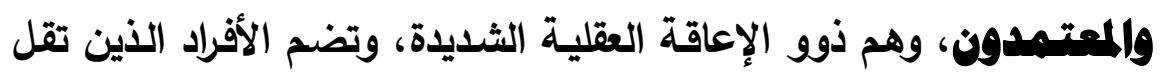

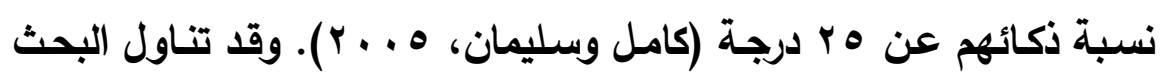

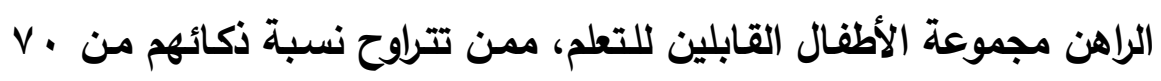

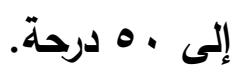

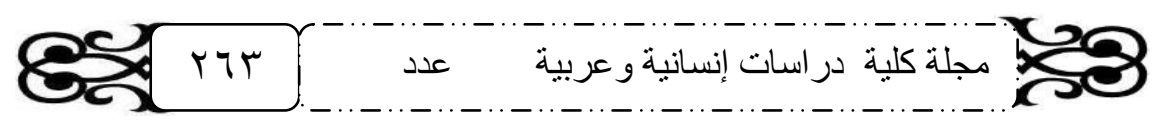


28

\section{ثانيا: الأداء الوظيفي الأسري:}

يعد الأداء الـوظيفي الأسـري مـن المفـاهيم الهامـة لفهم الصـراع بين

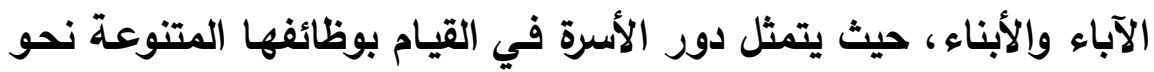

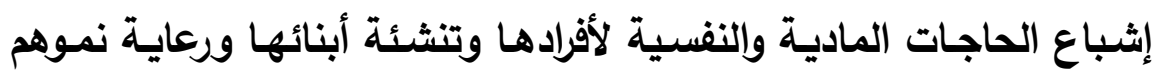
الجسمي والنفسي والعقلي والاجتماعي.

ومن ثم، يمكن تعريف الأداء الوظيفي بأنها أسلوب وطريقة الأسرة في

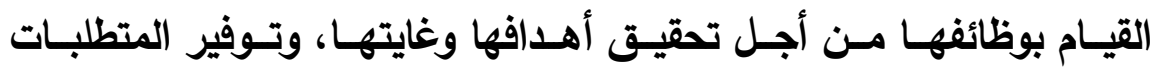

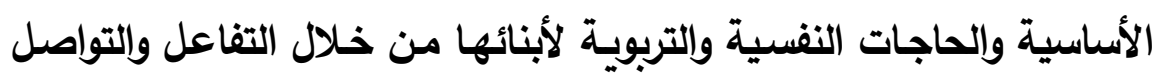

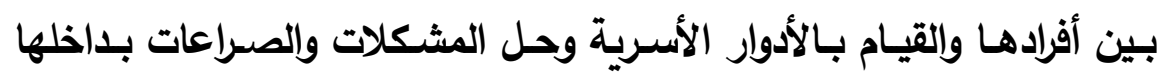

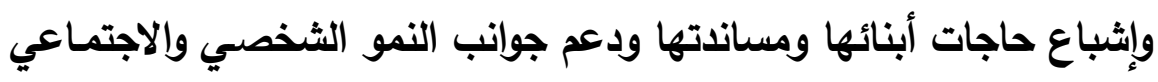
والضبط والتنظيم للايهم (عبد السلام، ؛ . . ب).

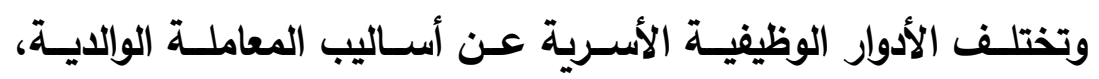

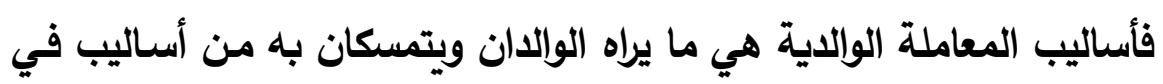

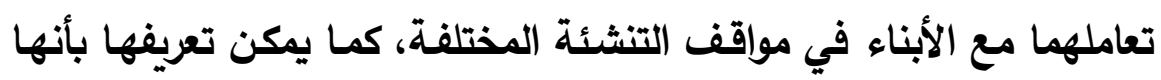

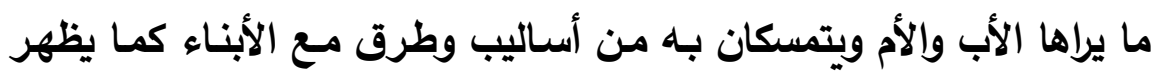
تقرير الأبناء اللفظي عن ذلك.

أما الاتجاهات الوالدية فتعبر عن مواقف الآباء نحو أبنائهم في مواقف

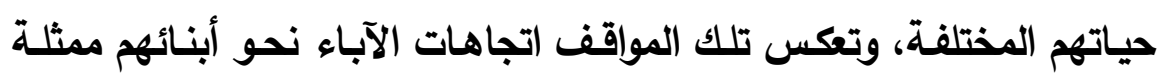

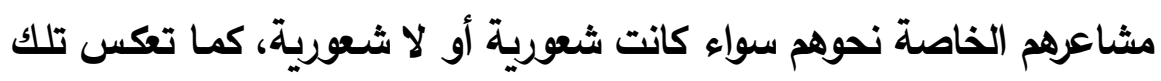

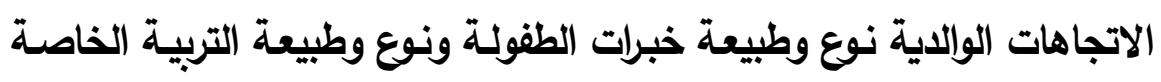
للآباء كما تمثلها أساليبهم التربوية في عملية التنشئة الاجتماعية ومواقفها.

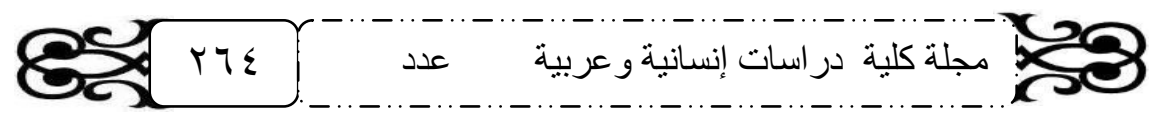


28

أمـا التنشـئة الاجتماعيـة داخل الأسـرة فهـي تلـك العمليـة التفاعليـة

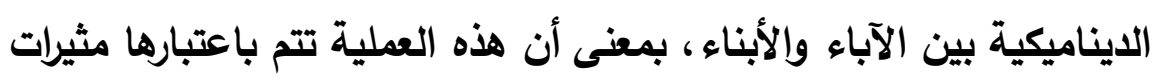

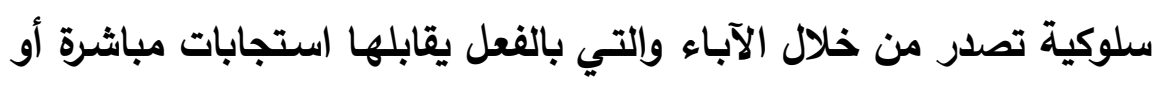

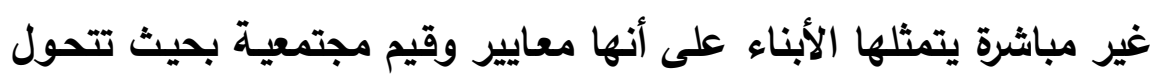

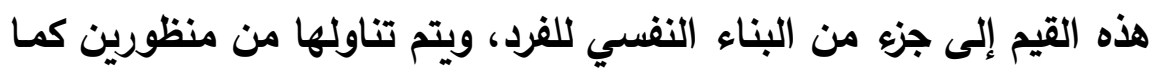

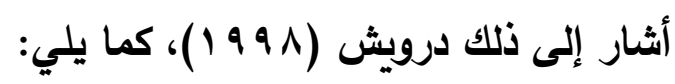

1- باعتبارها أساليب معاملة تصدر من الآباء تجاه أبنائهم ويمثل

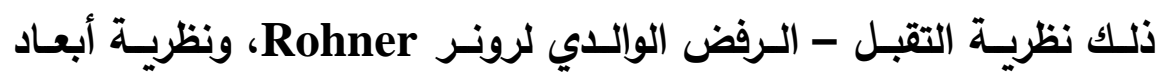
المعاملة الوالدية لثيفر Scheafar.

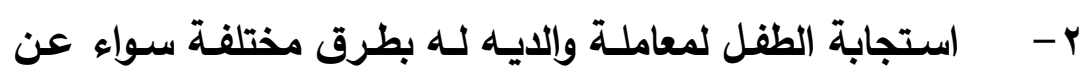

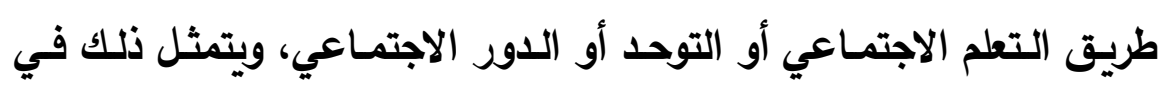
نظرية التعلم الاجتماعي ونظرية الدور الاجتماعي ونظرية التوحد.

\section{ثالثَ: السلوك التكيفي:}

تعد الأسـرة هـي البــرة الأولـى التـي تثـكل الطفل وتكسبه المهارات

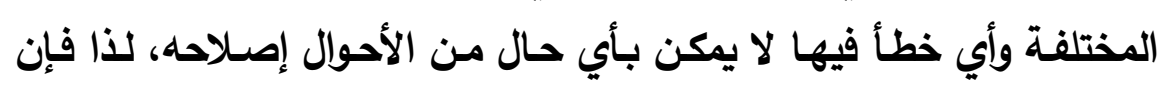
إساءة معاملة الأطفال منذ صغرهم يساعد على عدم إكساب الطفل المهارات الللازمسة للتكيف. وتعتبر القدرة على التكيف من المهارات الهامسة وإللازمسة

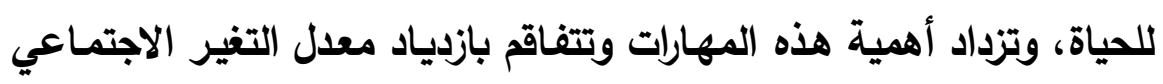

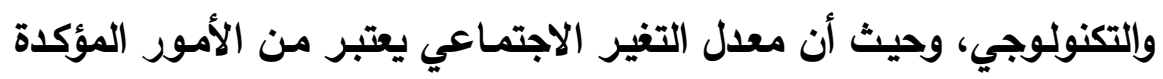

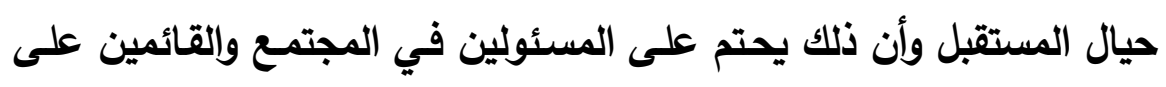

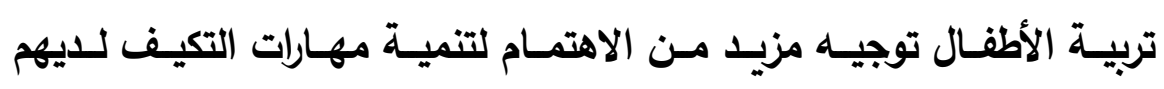

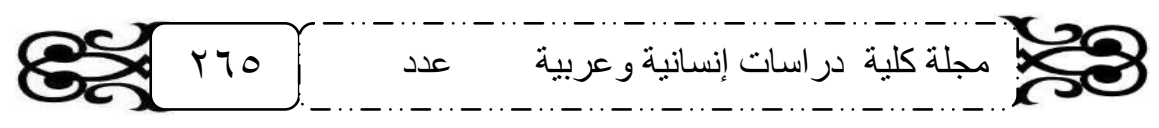




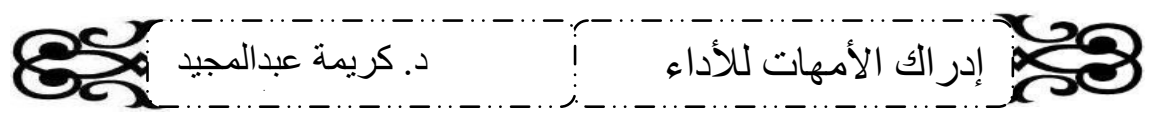

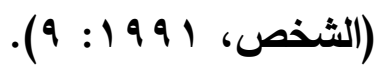

وقد نشـأ مفهوم التكيف في بادئ الأمر ضمن علم البيولوجيا، كمـا أشار إليه تثارلز دارون Charles Darwin في نظرية النشوء والارتقاء عـام 1 ا 1 والتـي أقر فيهـا أن الكائنـات الحيـة التـي تسـتطيع البقـاء والمحافظة على نوعها تلك التي تستطيع أن تتواءم مـع أخطار وصعوبات العـالم والبيئة الطبيعيـة، وهـو مـا عبـر عنـه دارون بالانتخـاب الطبيعي

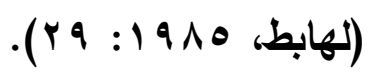

ويتسع المفهوم في مجال العلوم الاجتماعية ليشمل التكيف المعرفي (العقلي) والاجتماعي للبيئة الاجتماعية لكي يحصل على المعززات لسلوكه يســح لـه بالاسـتمرار في الوحدة الاجتماعيـة التي ينتمـي لها. وقد بـأ Social الحــيث عـن السـلوك التكيفـي بفكـرة القــرة الاجتماعيـة Comperency

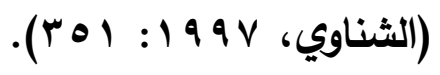

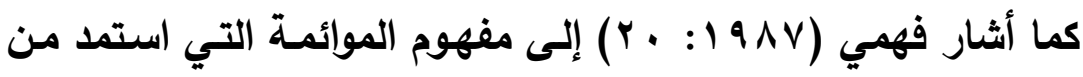
علـم البيولـوجي، وتسـتخدم تحـ اسـم التكيـف Adaptation في علـم النفس، واهتم علماء النفس بالبقاء السيكولوجي عن البقاء الفيزيقي كما يضم علم البيولوجي مفهوم الموائمة الذي يفسر السلوك الإنساني على أنه عملية تكيف للمطالب والضغوط والمواقف، وهذه المطالب عادة مـا تكون اجتماعية أو نابعة من العلاقات بين الأفراد.

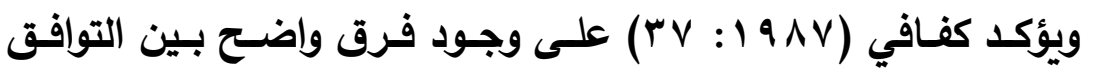
والتكيف، حيث يثير التوافق إلى تغيرات في السلوك التي تكون ضروريـة حتى يتم الإثباع في إطار العلاقات المنسجمة في المجتمـ، أمـا التكيف

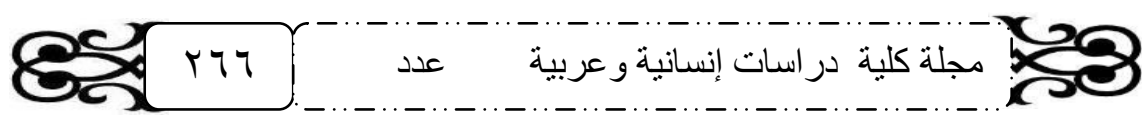


28

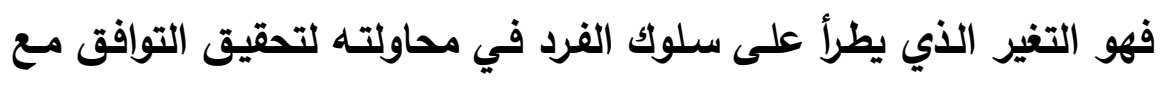

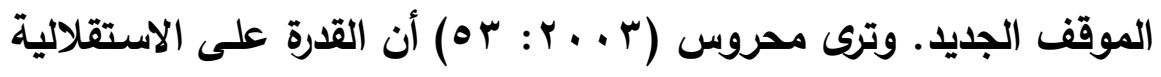
وقدرة الفرد على مقابلة حاجاته المادية تعتبران من العلاقات المميزة للأفراد

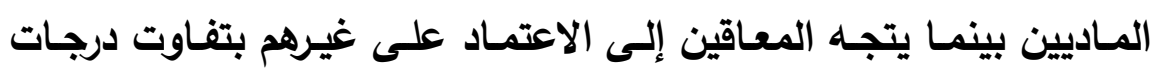

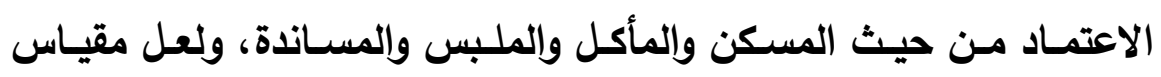

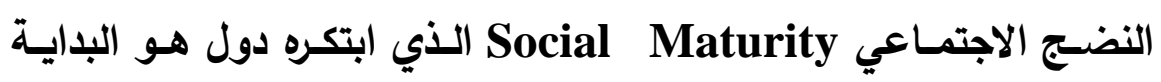
الحقيقية للتعرف على القدرات العقلية الحقيقية للأفراد في مواقف الحياة

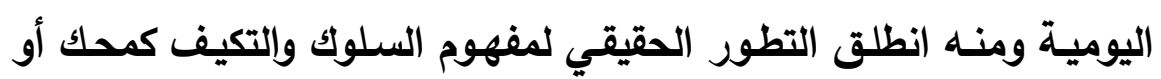
أداة يمكن الاعتماد عليها في الحكم على حالات الإعاقة.

ويمثل معيار السلوك التكيفي متعدد اللدرجات ومقياسـاً ثابتاً للتعرف

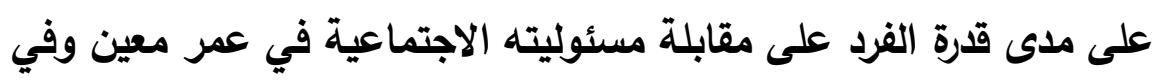

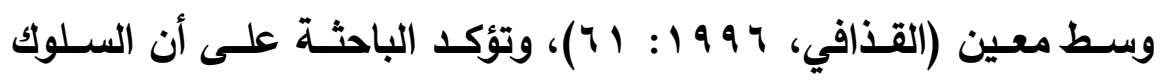

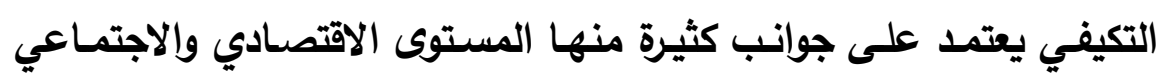

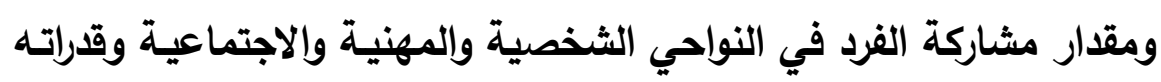
العقلية لكي تتم عملية التواصل.

وإلى جانب هذا، ظهر مفهوم السلوك التكيفي في علم النفس لأول مرة عندما استخدم جيزل (9 \9 19) هذا المصطلح ليصف به به المستوى المهاري

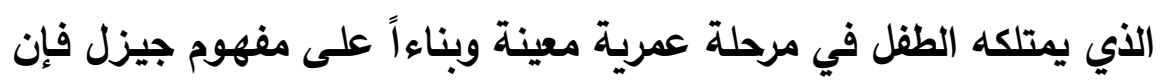
السلوك التكيفي للطفل يمر بمراحل عمرية مختلفة (صادق، ه191 1: r). وتطور مفهوم السلوك التكيفي وزاد انتشاره نتيجة سوء تقدير نسب الأكاء وعدم وجود معيار دقيق وموحد لتصنيف الأطفال المتخلفين عقلياً

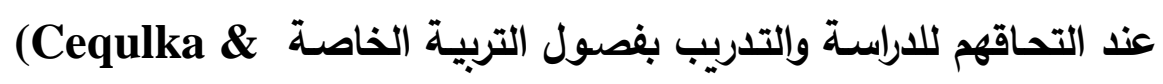

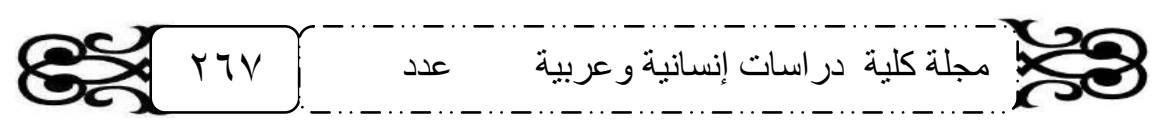




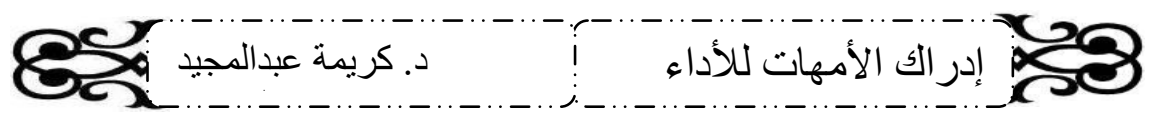

Prehm, 1911) وقد تحددت وجهات النظر بثأن تحديد مفهوم السلوك

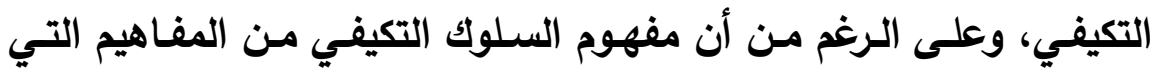

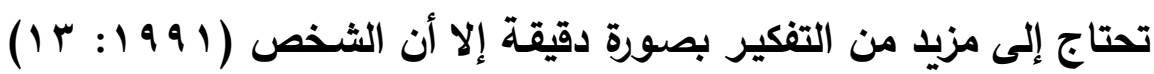

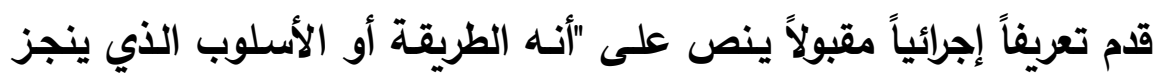
به الأطفال الأعمال المختلفة المتوقعة من أقرانهم في العمر الزمني". وتم تعريف السلوك التكيفي بأنسه: "درجـة الفاعلية التـي يقابل بها

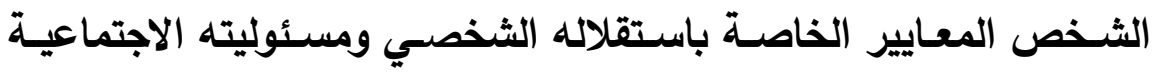

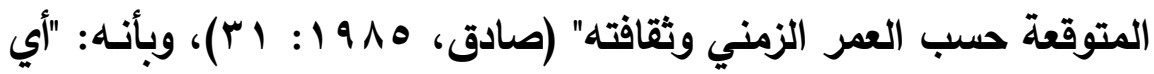

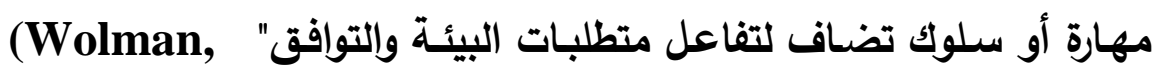

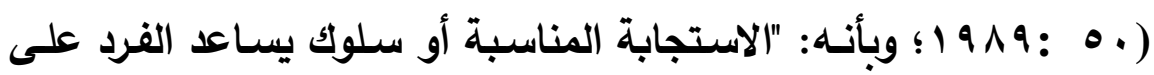

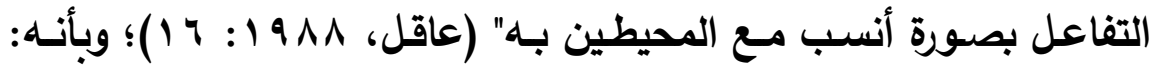

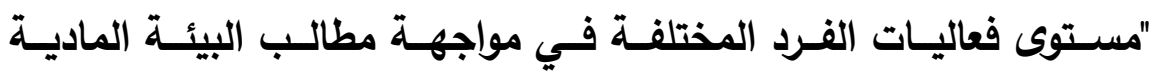

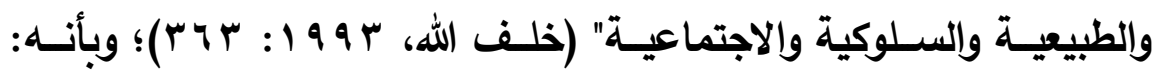
"قدرة الفرد على الاستقلالية وتحمل المسئولية الاجتماعية" (Henley, et)

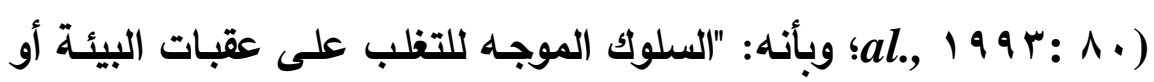
صعوبات موقفها. كما أن آليات توافقه التي يتعلمها هي استجابته المعتادة

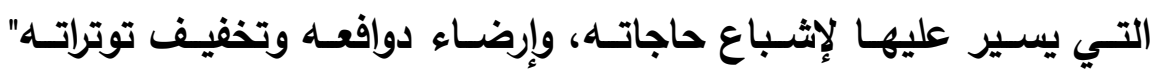

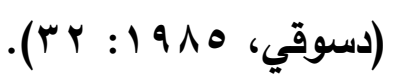

ويتحدد السـلوك التكيفي بدرجـة الفاعليـة التـي يقابـل بها الثـص المعايير الخاصة باستقلالية ومسئوليته الاجتماعية المتوقعة منه من خلال

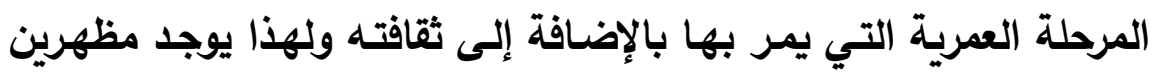
أساسيين هما القدرة على التعلم والتدريب الوظيفي، والقدرة على مواجهة

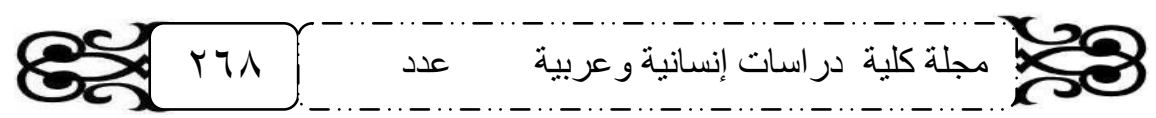




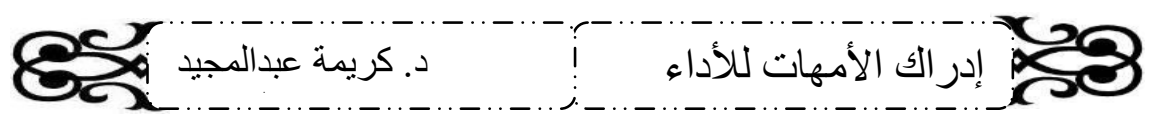

المطالب الاجتماعية (حافظ، ب 99 1 : 1 19 ).

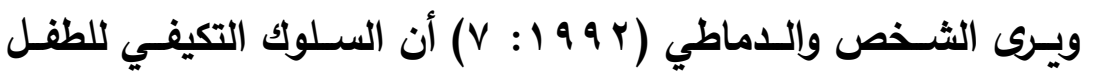
يمكن التعرف عليه من خلال معرفة الأداء الوظيفي الذي يتمثل في خمسـة مجالات والتي تمثل أبعاد السلوك التكيفي؛ وهي كما يلي: 1 - النـمــو الالغـوي: يقيس هذا المجال نمو المهارات على الأسـاس الاجتماعي. ץ - الأداء الوظظفي المستقل: يقيس هذا المجال مستوى العمر الذي يستطيع الطفل عنده تحمل المسئولية. ["] [جم الأسرة: يعد حجم الأسرة ذات تأثير كبير على السلوك التكيفي للمعاق، فالأسرة كبيرة العدد تقلل من الرعاية التي ينالها أبناؤها، وبالتالي ينخفض مستوى السلوك التكيفي للطفل بعكس الأسرة قليلة العدد، نجدها توفي بالاحتياجات الضـرورية للطفل وتزداد الرعايـة، فالاحتياجـات الماديـة قد تشبع مـع قلـة

\section{[\&]}

يلعب المستوى الثقافي دوراً بارزاً في تأثيره على السلوك التكيفي للطفل المعوق، فالأسرة التي تتميز بمستوى ثقافي مرتفع تسهم بدورها في رفع مستوى قدرات المعوق بعكس الأسر ذات المستوى الثقافي المنخفض التي تعرض طفلها للإحباط والفشل، والعجز عن مواجهة المواقف، وقد أتضح من خلال العديد من البحوث أن الأسـر ذات المستوى الثقافي المرتفع يوفرون

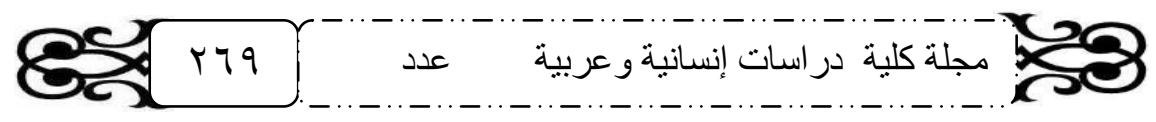


28 إدرالى الأمهات للأداء

للطفل الرعاية والعناية والتعامل معه بطريقة سوية فتفهم متطلباته وتكسبه

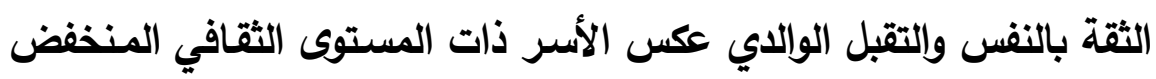

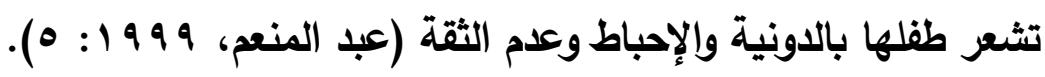

\section{] [0] المتروى الاجتمباهي الاقتمادي:}

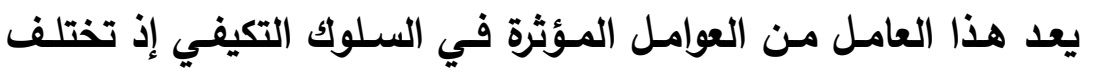

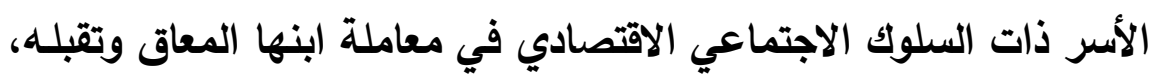

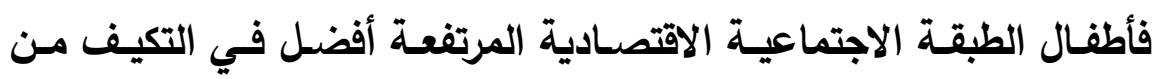

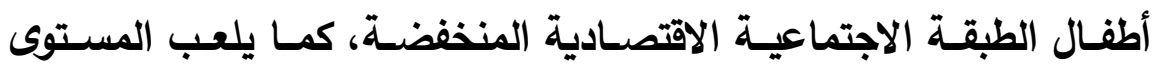

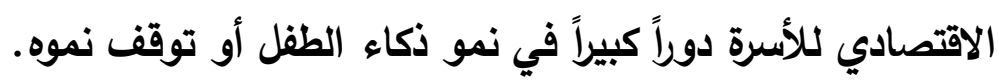

\section{نظريات عام النفس والسلمك التكيفي:}

تتناول الباحثة مفهوم السلوك التكيفي من وجهة نظر كل من مدرسـة التحليل النفسي والمدرسة السلوكية والاتجاه الإنساني.

\section{['] وجمة نظر التمليل النفسي:}

تنظر مدرسة التحليل النفسي إلى حالة عدم التكيف على أنه يحدث

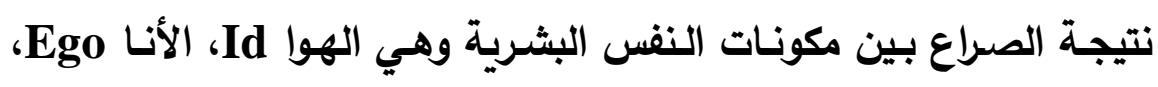
الأنا الأعلى Super Ego وذلك يكون التوافق هو محاولة إزالة الأساليب بدلاً من محاولة التخلص من الأعراض.

ويعيش الفرد في حالة صراع دائم بين دوافعه الثخصية التي لا يقرها

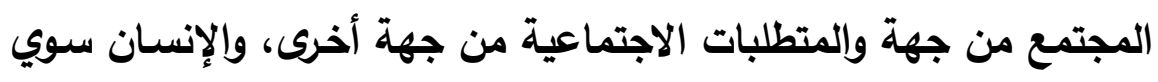

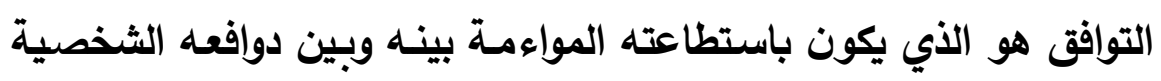

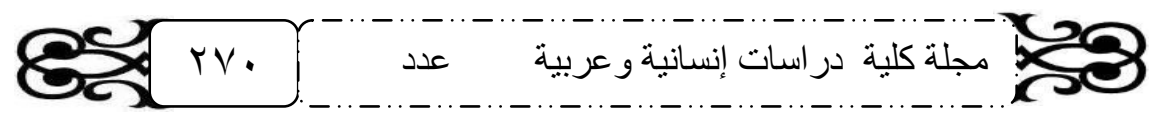




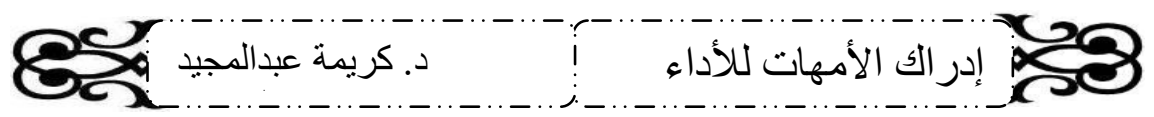

ومتطلباته الاجتماعية.

كما يـكر فرويـا بأن السـوك الإنسـاني ينشط عندما يكون في حالـة استثارة وتوتر أي يتعرض لحالة عدم اتزان حتى يصل إلى حالة التوازن، كما

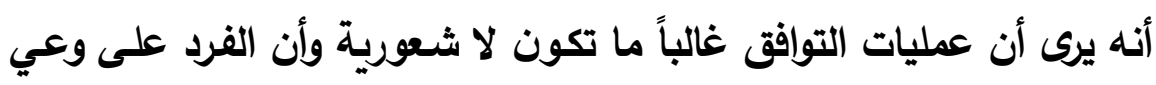
بالأسـباب الحقيقيـة أكثر مـن سـلوكية، هـا وقد عبـر الفرويـديون الجـد إربكسون، وفروم، وموراي عن استيائهم من وجهة نظر فرويد للإنسان إذ يرون أن بعض عمليات التوافق قد تكون شعورية غالباً وأن الإنسان يمكن

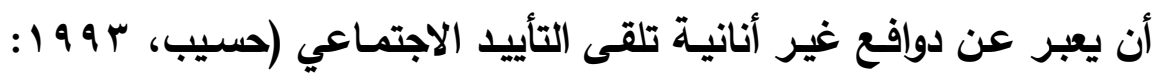

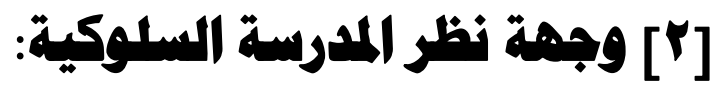

يقوم تصور مفهوم التكيف عند السلوكيين على قدرة الفرد لاكتسـاب مجموعة من العادات المناسبة والفعالة مع الآخرين والتي سبق أن تعلمها، وأدت إلى بعض توتره وقلقه أو نجحت في إثباع دوافعه وحاجاتـه، وبذأك دعمت وأصبحت سلوكاً يستدعيه الفرد كلمـا وقف في نفس الموقف مرة أخرى.

كما يرى واطسون وسكنر أن التوافق عبارة عن تعلم الفرد لمجموعة من العادات السلوكية المكتسبة من البيئة والتي يمكن عن طريقها إثباع حاجاته المختلفة، وأن تعلم هذه الاستجابات يتم بصورة آلية وبدون قصد شعوري خاصة في سنوات عمره الأولى، فالهدف الأساسي للمسـاعدة هو إحـلال مجموعـة مـن العـادات السـلوكية النافعـة أو التكيفيـة محل العـادات

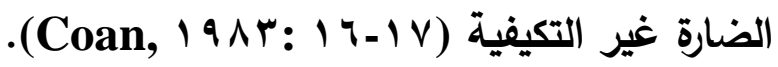

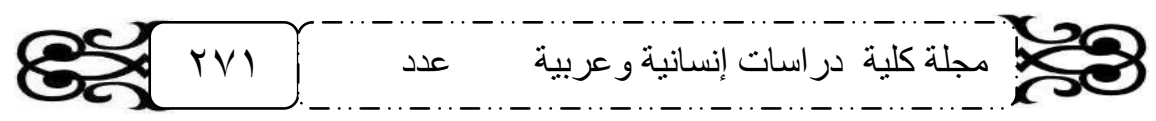


28

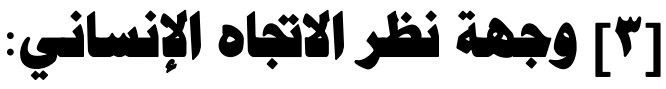

يؤكد أنصار الاتجاه الإنساني على خصوصية الإنسان بين الكائنات

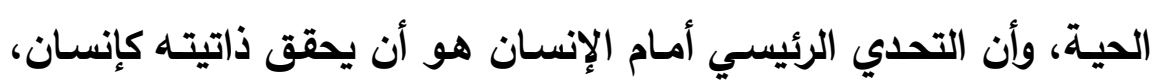

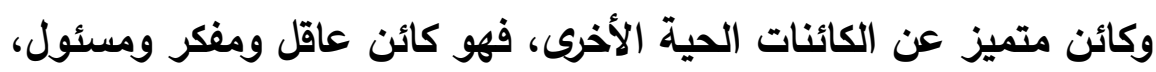

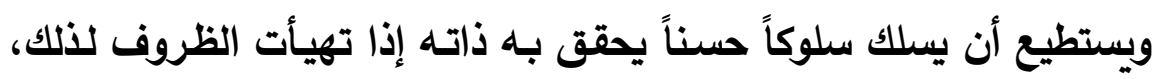
ومن أهم السلوك المرتبط بالتوتر وسوء التوافق عند أصحاب هذا الاتجاه بحث الإنسان عن هدف أو مغزى لحياته يحقق به ذاته وإذا لم يهتدي إلى الهى

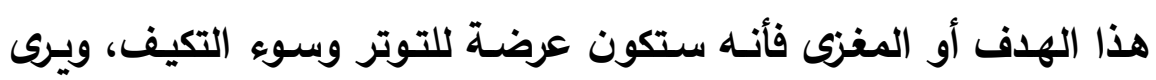
ماسلو أن الثخص المتوافق هو الثخص الذي يستطيع أن يحقق ذاتـه لـانه

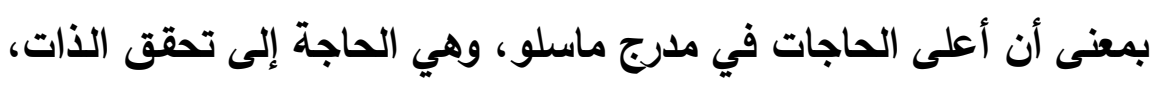

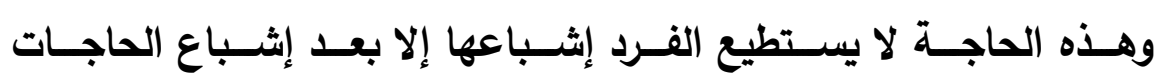

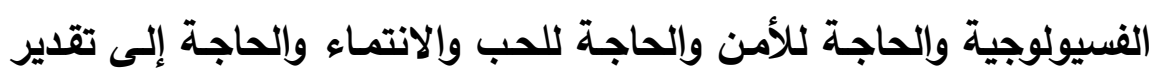

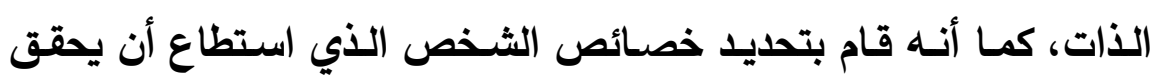

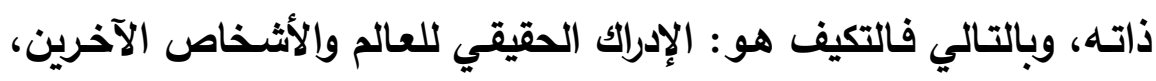

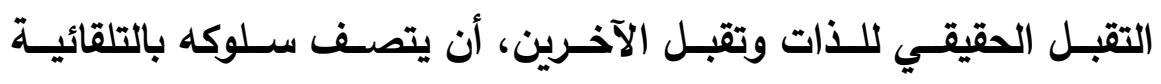

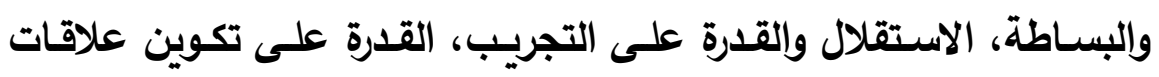

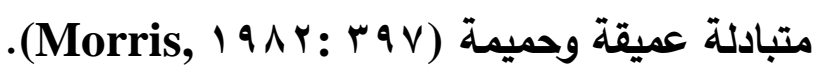

\section{بحوث سابقة:}

قامست اللحامي (ـ 9 1 1) بلراسـة الاتجاهـات الوالديـة نحو المتخلفين

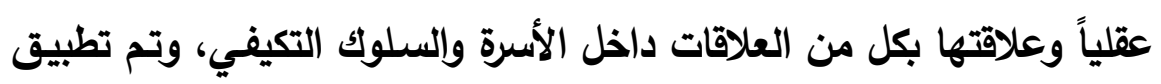
مقياس السلوك التكيفي، ومقياس العلاقات الأسرية، ومقياس ستانفورد -

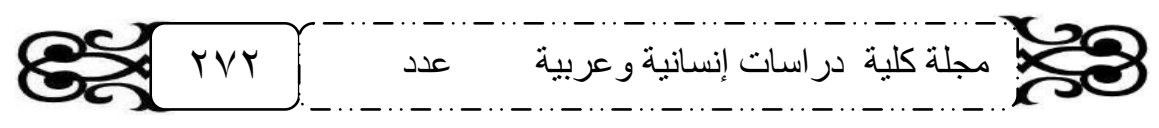




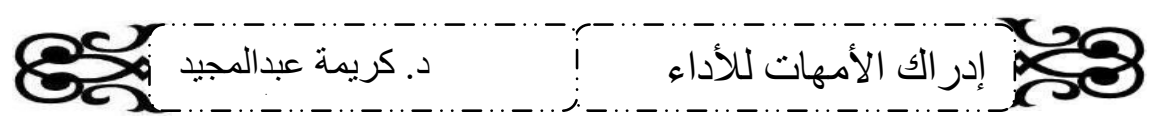

بينيه للانكاء، واستتمارة المستوى الاقتصادي، واستبيان الاتجاهـات الوالديـة

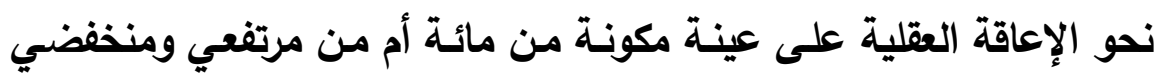

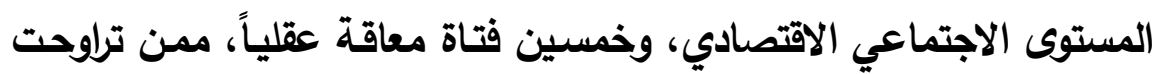

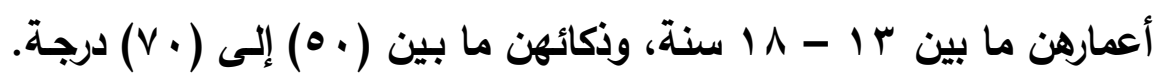
وأنتهت النتائج إلى وجود علاقة بين الاتجاهات الوالدية نحو الإعاقة العقلية

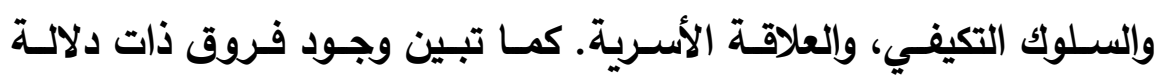

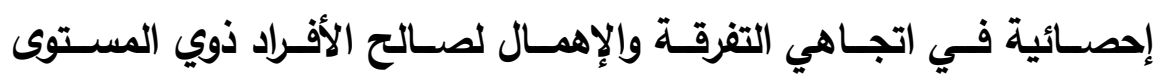
الاقتصادي المرتفع.

وتناول محمد (1991) اتجاهات الآباء نحو أبنائهم المتخلفين عقلياً

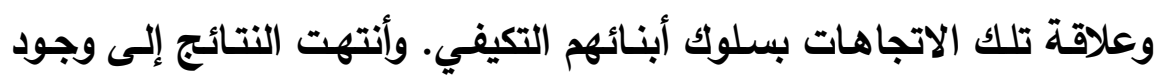
فروق دالة إحصائياً بين ابناء ذوي الاتجاهات العالية وأبناء ذوي الاتجاهات المنخفضـة في بعض أبعـاد مقيـاس السـلوك التكيفي، لصـالح المـرتفعين.

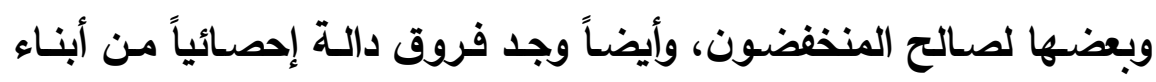

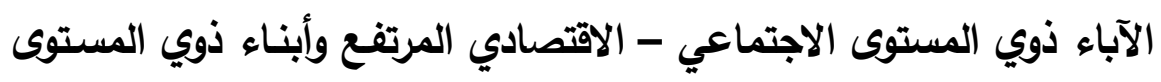

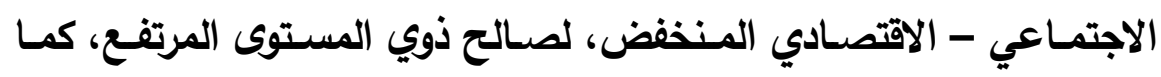
وجد علاقة ارتباطية بين اتجاهات الآباء والسلوك التكيفي لأبنائهر.

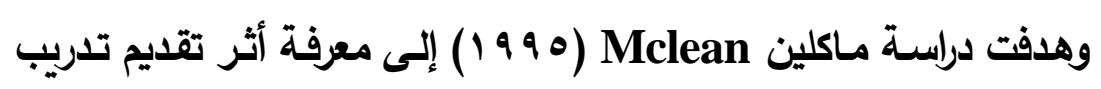
للأسرة التي لديها أفراد معوقين عقلياً ويعيشون في مؤسسات داخلين الفية. وقد تم تقييم أثر التدريب على التطور التكيفي الخاص بالأفراد المعاقين عقلياً. وقدا

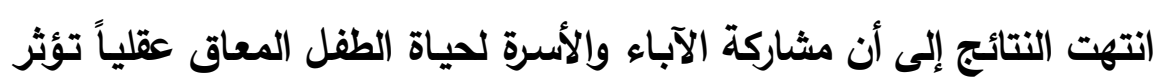
في سلوكه التكيفي. وهدفت دراسة علي (1999) إلى معرفة تأثير الاتجاهات الوالدية على S2 


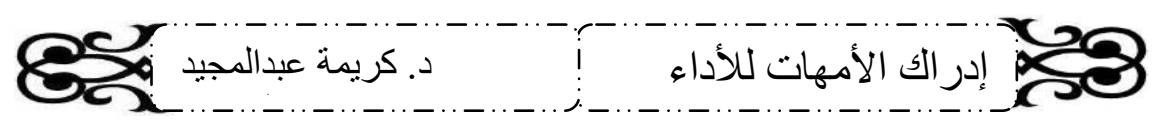

السلوك التكيفي للطفل المعوق عقلياً والمصابين بأعراض داون. ولتحقيق

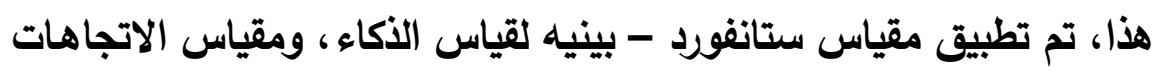

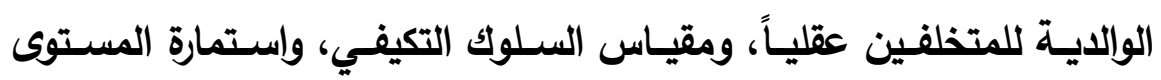

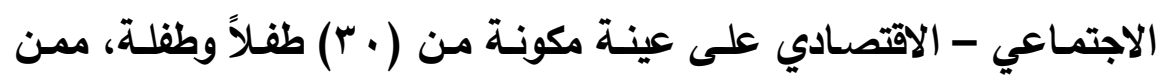

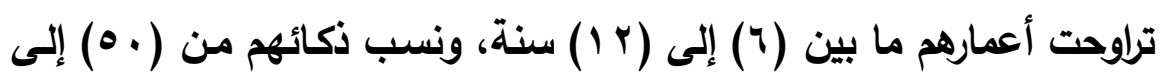

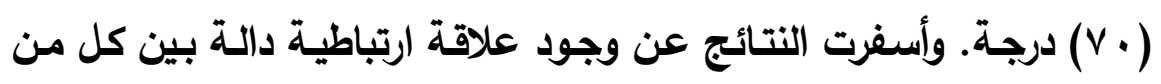

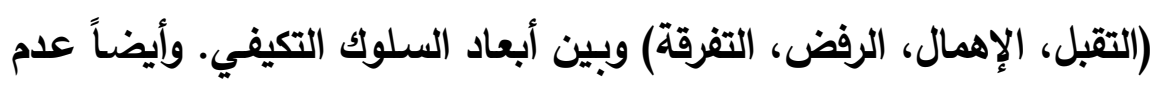

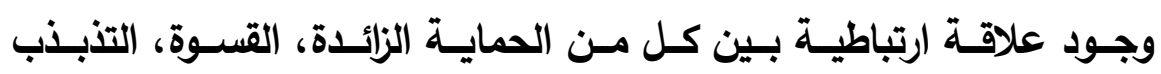

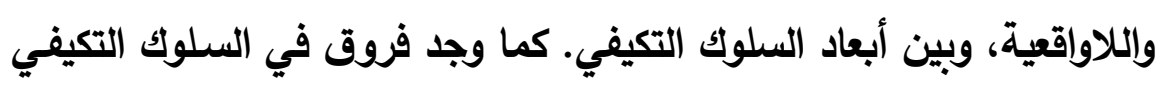

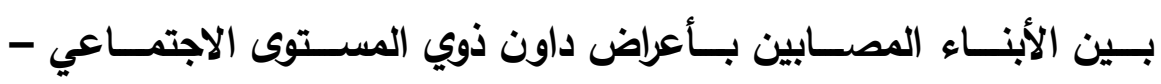

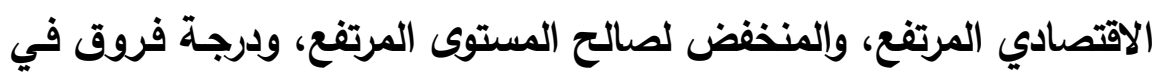

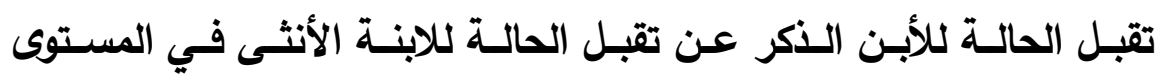

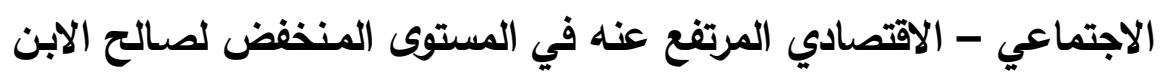

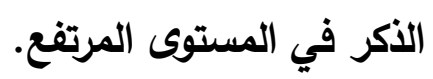

وكثفت دراسـة سيميل Semel (997 (199 ) عن معرفة العلاقة الارتباطية

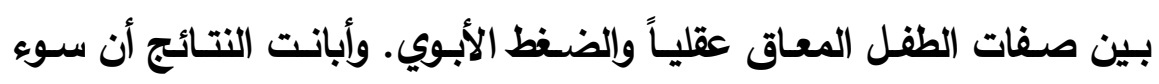

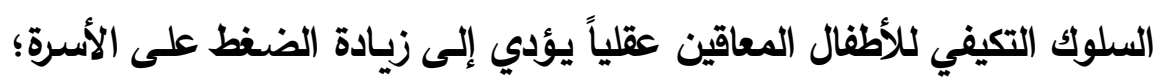
مما يضعف من المناخ الأسري كله. وهدفت دراسة لايت Litt (99v ( ) إلى معرفة ارتباط السلوك التكيفي

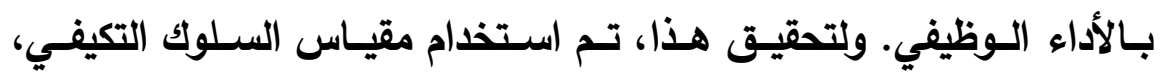

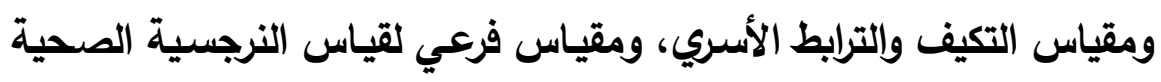

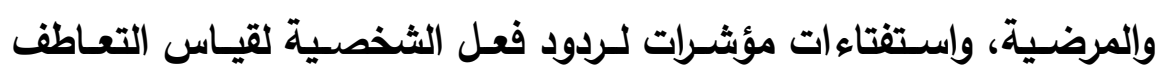

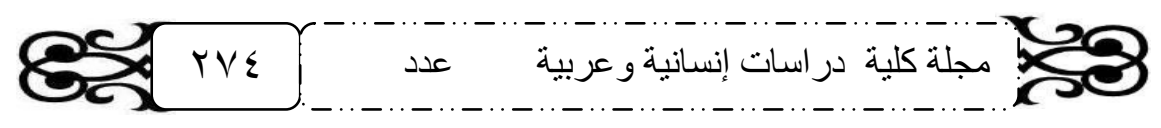




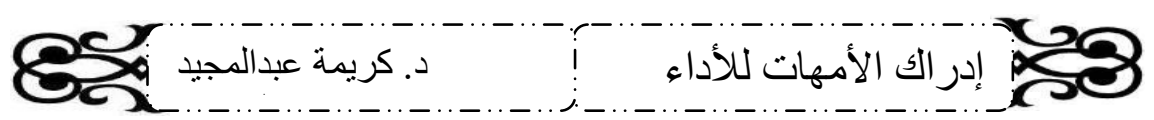

الوجداني. وأسفرت النتائج عن وجود علاقة بين البناء الأسري والسلوك التكيفي، حيث يؤثر الترابط الأسري على كافة جوانب السلوك التوانئ التكيفي للطفل

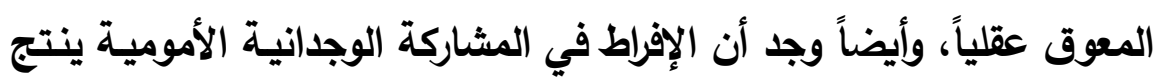
عنه زيادة سوء السلوك التكيفي. وتناولت دراسة ماكلينتون Maclinton (9 9 V ( ) أثر مشاركة الآباء

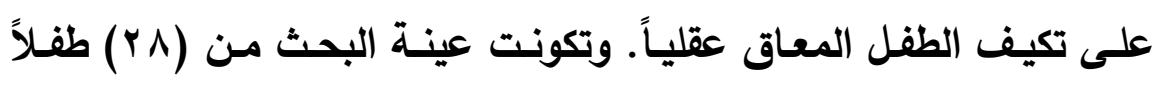
معاقـاً عقلياً, وقــ تــ تطبيـق مقيـاس النقـاط الوقتيـة الثنائيـة والأسـئلة

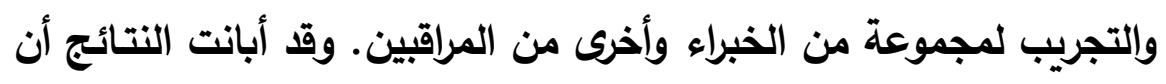
مشاركة الآباء مع بعضهم يؤدي إلى قلة المشاكل السلوكية لدى الأطفال

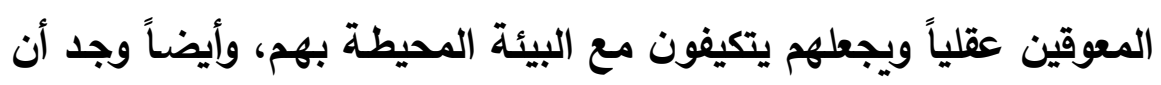

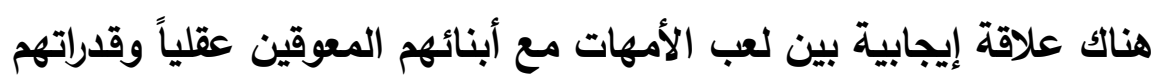
على حل المشاكل التي تواجههم.

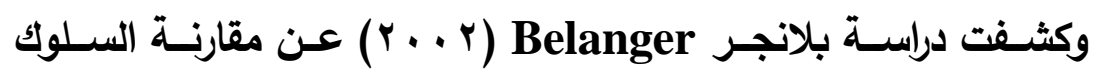
التكيفي ونسبة المرض النفسي بين الأطفال المعاقين عقلياً الذين يتلقون

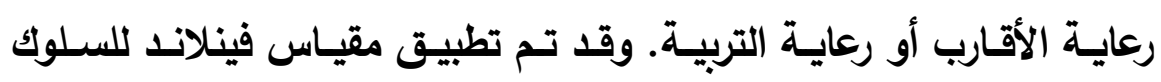
التكيفي ومقياس ديفوركس للاضطرابات العقلية على مجموعة من الأطفال

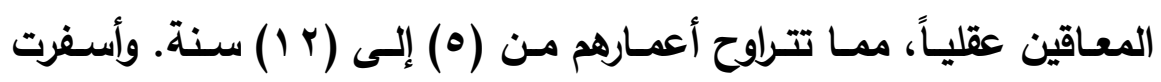

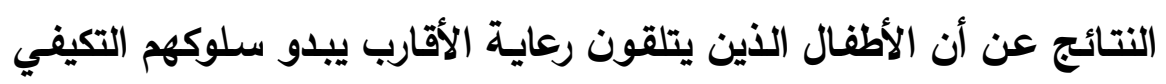
أفضل من الأطفال الذين يتلقون رعاية التربية.

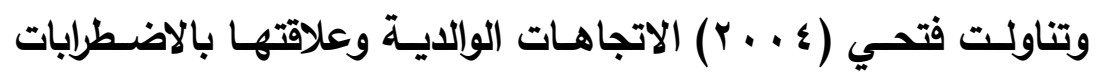

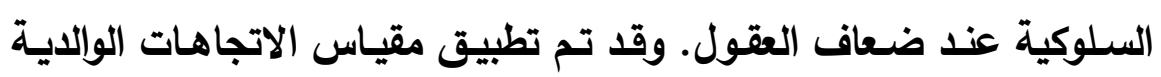

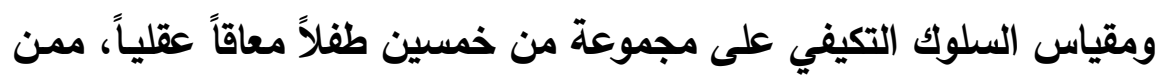
S2 


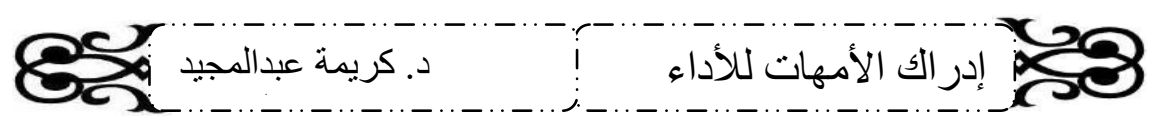

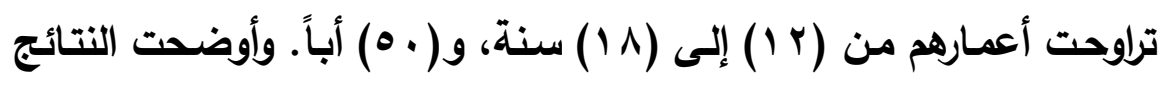

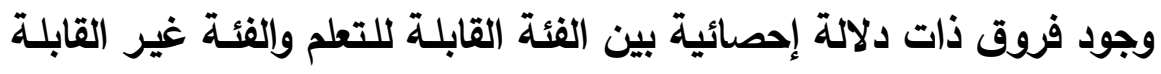

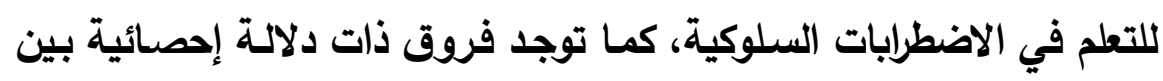

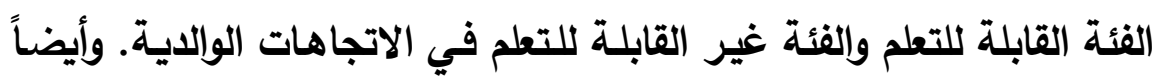

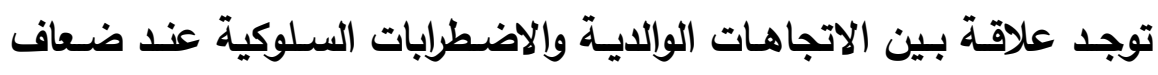
العقول.

وكثـفت دراسـة حسـين (9 . . ب) المنــاخ الأسـري وعلاقتـه بالسـلوك

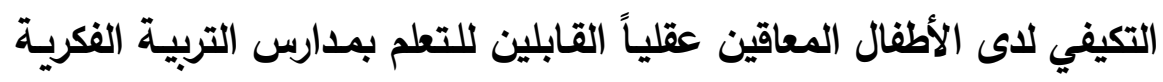
وقد تم تطبيق مقياس العلاقة الأسرية والتطابق، ومقياس السلوكئ التئن التكيفي

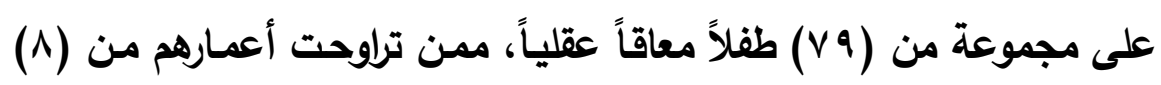

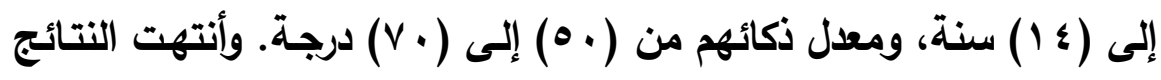

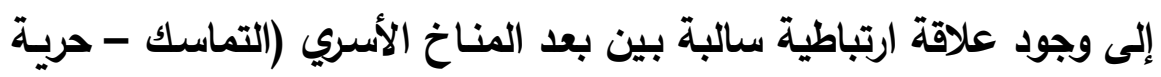

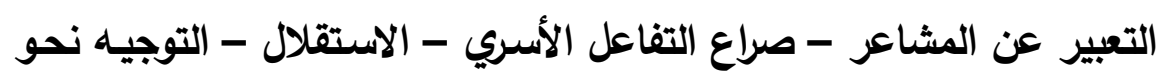

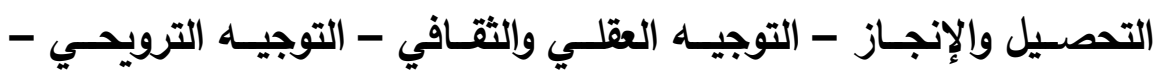
التوجيـه نحو القيم الاينية والخلقيـة - التنظيم - الضبط) ككل بكل أبعاده والانحرافات السلوكية لاى الأطفال المعاقين عقلياً القابلين للتعلم.

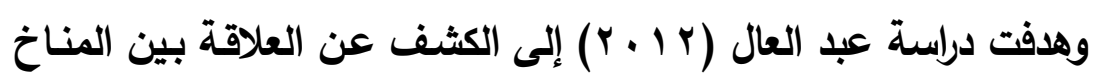

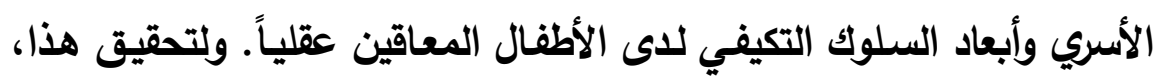

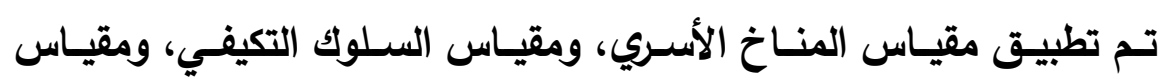

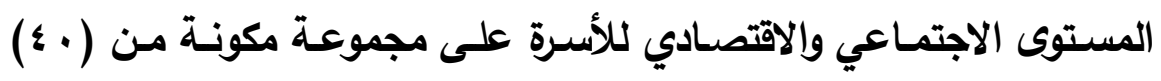

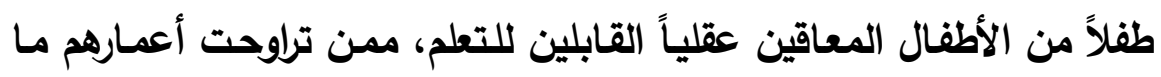

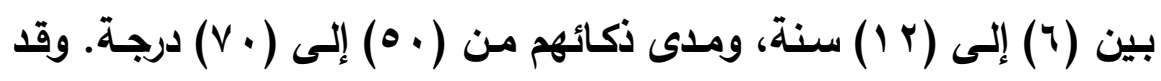

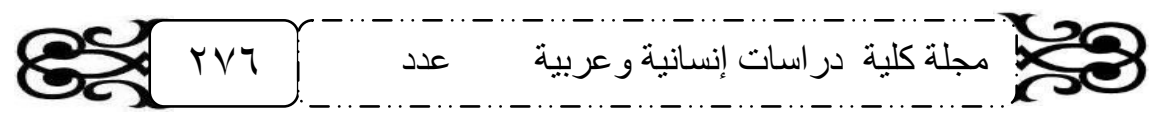


28

أوضـحت النتائج وجـود علاقـة موجبـة دالـة إحصـائياً بين المنـاخ الأسـري والجانب النمائي من السلوك التكيفي، بينما توجد علاقة سالبة دالة إحصائياً

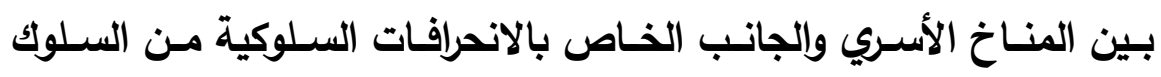

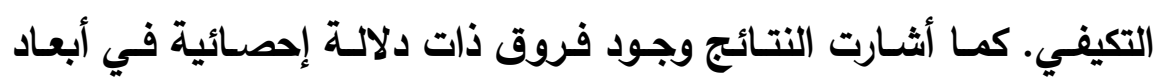

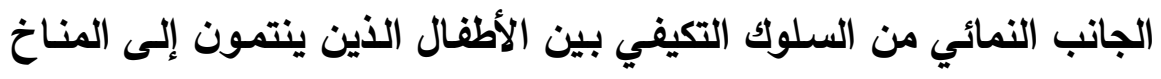

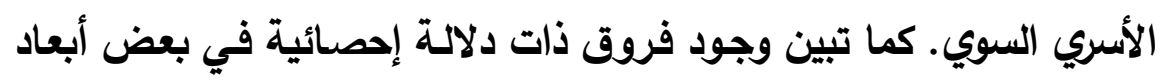

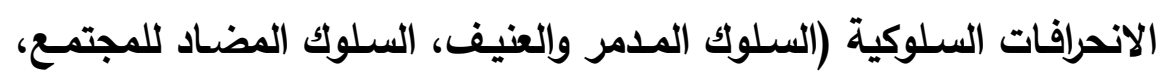

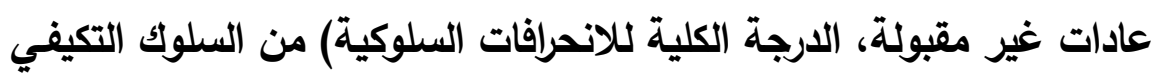

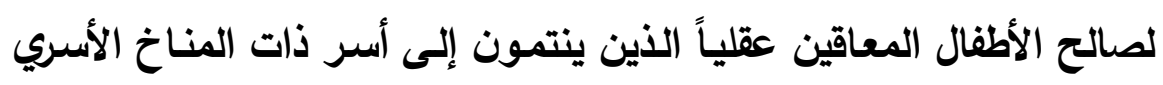
غير السوي.

ومسن خـلال مراجعـة الباحثة للبحوث السـابقة المـذكورة سـلفاً تبـين أن

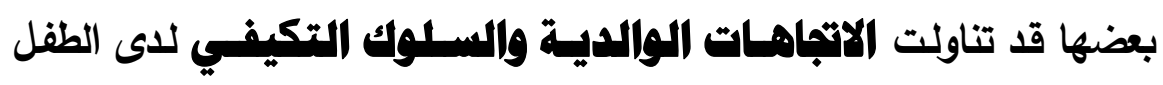

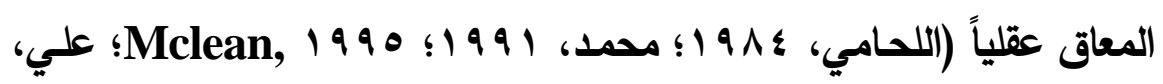

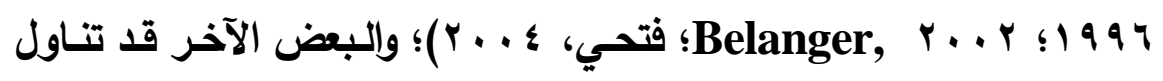
Semel, المناخ الأسري والسـلوك التكيفي لدى الطفل المعاق عقلياً

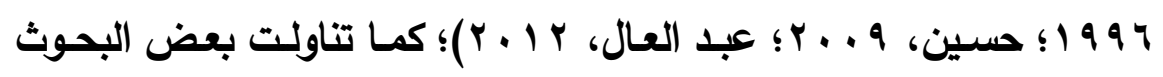

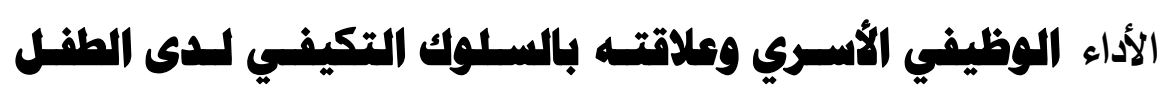

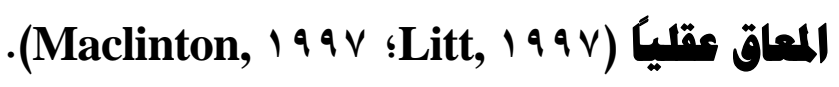
ومن ثم، أوضحت البحوث السابقة المثـار إليها سـابقاً قلـة البحوث

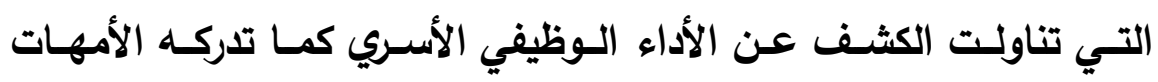

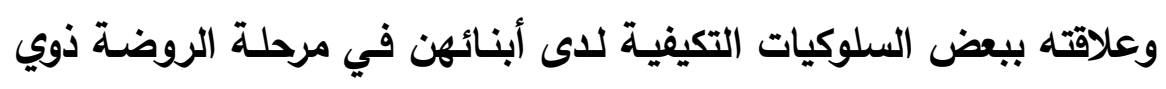
الإعاقة العقلية البسيطة. وعليه تكمن مشكلة البحث الراهن في محاولية S2 
التعرف على طبيعة العلاقة بين الأداء الوظيفي الأسري كما تدركه الأمهات ببعض السلوكيات النمائية لدى أبنـائهن في مرحلـة الروضـة ذوي الإعاقة العقلية البسيطة. 


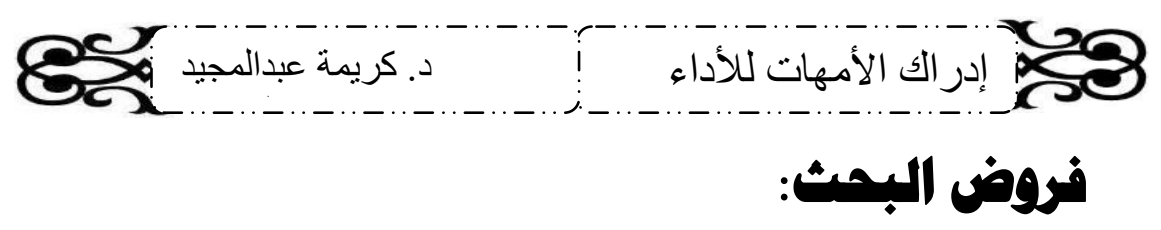

يمكن صياغة فروض البحث على النحو التالي:

1 - يوجد ارتباط ذو دلالة إحصائية بين الأداء الوظيفي الأسري المدرك من قبل الأمهات وبعض الجوانب النمائية من السلوك التكيفي لادى أبنائهن ذوي الإعاقة العقلية البسيطة.

ץ - توجد فروق ذات دلالة إحصائية في أبعاد الأداء الوظيفي الأسري

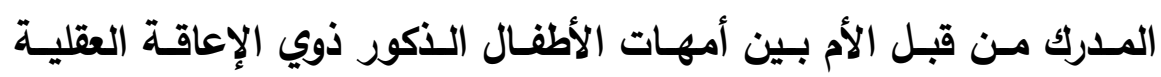
البسيطة وأمهات الأطفال الإناث ذوات الإعاقة العقلية البسيطة. r- توجد فروق ذات دلالـة إحصـائية في بعض الجوانب النمائيسة مـن

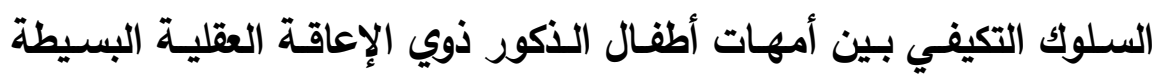
وأمهات الأطفال الإناث ذوات الإعاقة العقلية البسيطة.

\section{منهم البمث وإبراء|ته:}

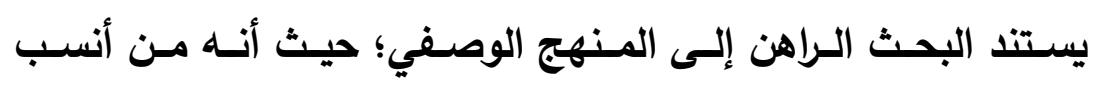
المناهج لتحقيق أهدافه.

\section{عينة البمش:}

تكونت عينة البحث من ستين أماً، من أمهات الأطفال ذوي الإعاقة

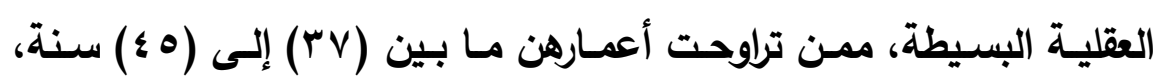

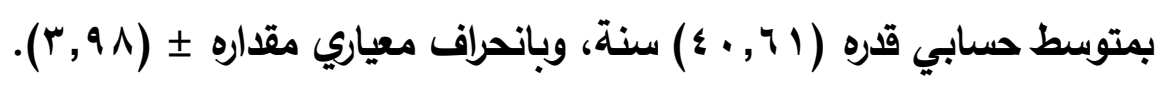

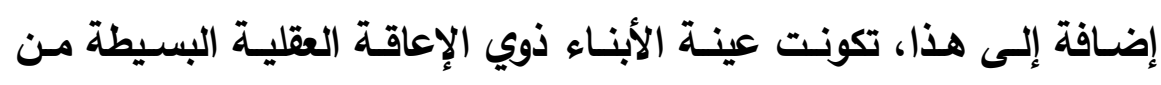

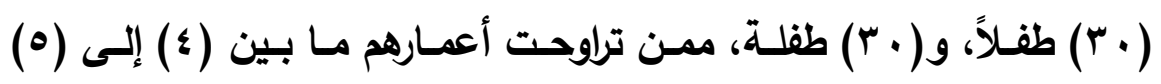
28 


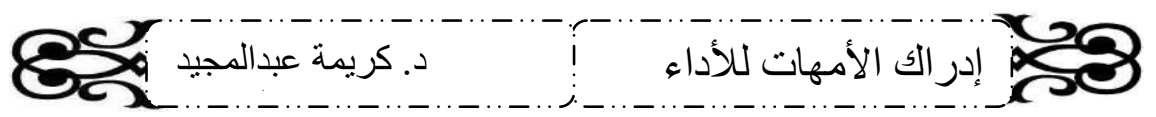

سنة، بمتوسط حسابي قدره (1 (9, ؛ ) سـنة، وبـانحراف معياري مقداره

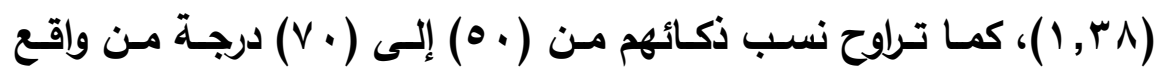

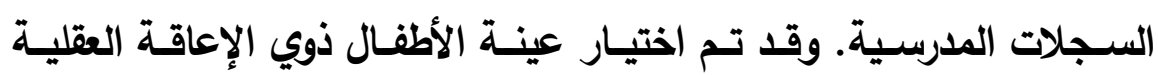

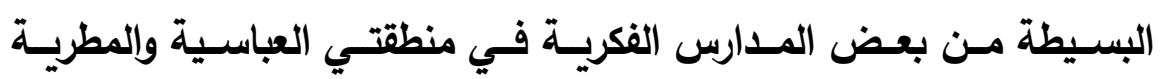
بححافظة القاهرة.

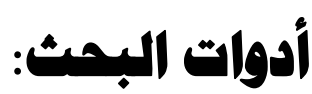

تم استخدام المقاييس النفسية التالية:

\section{['] مقياس الأداء الوظظهي الأهري:}

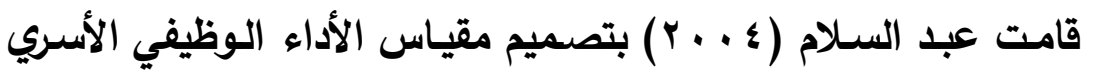
كما يدركه الأبناء، وهو يهدف إلى قياس أسلوب وطريقة الأسرة في القيام

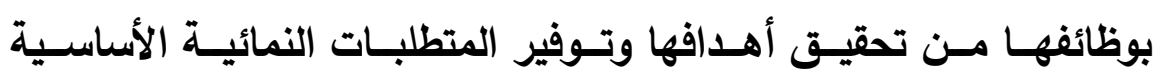

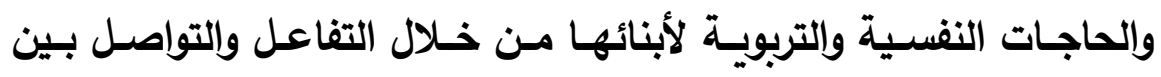

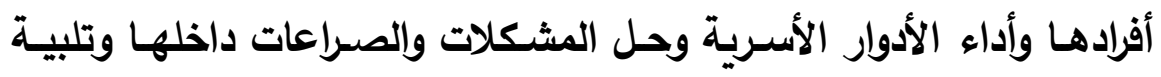

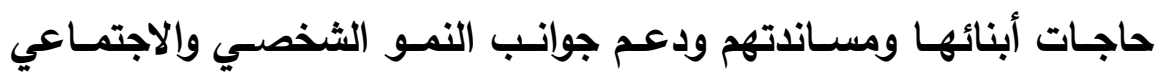

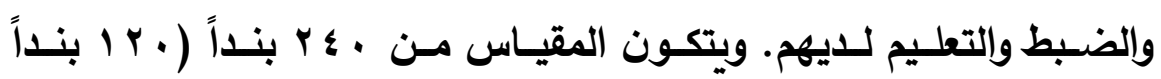

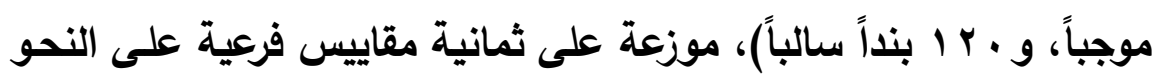

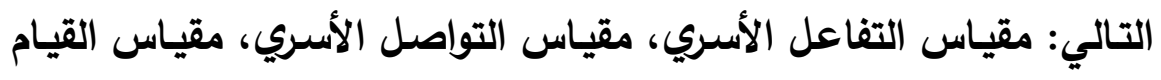

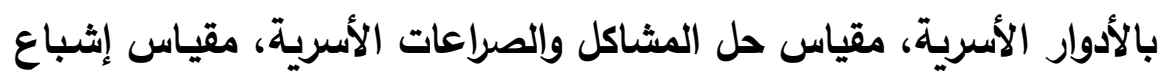

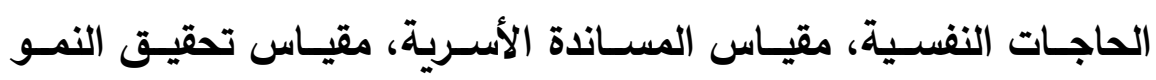

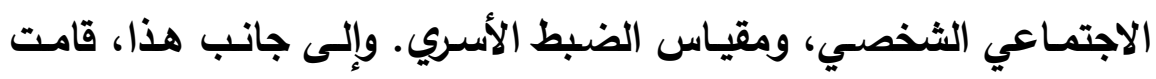

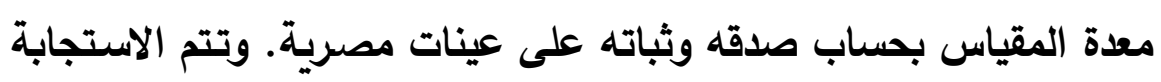
S2 14. 
28

على كل بند من خلال ميزان ثلاثي (غالباً - أحياناً - نادراً).

وقد قامت الباحثة الحالية بحساب ثبات مقياس الأداء الوظيفي الأسري

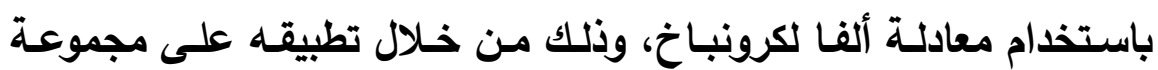
مكونة من (ro (ro) أماً من أمهات الأطفال ذوي الإعاقة العقلية البسيطة.

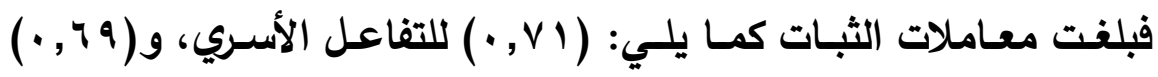

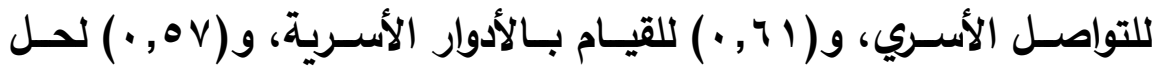

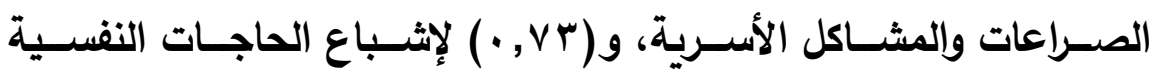

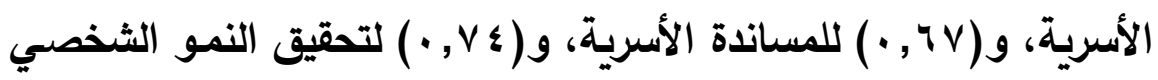

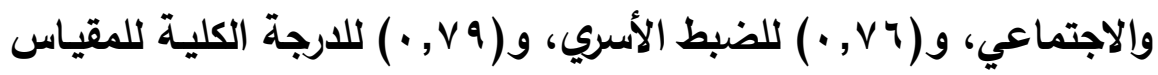
وكلها معاملات مرتفعة ومقبولة إحصائية.

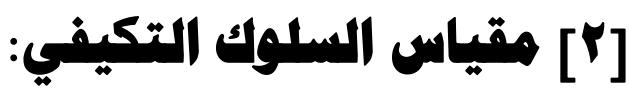

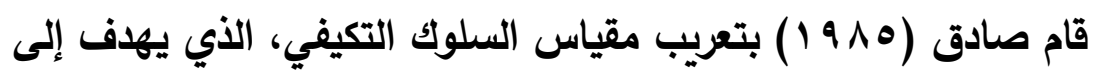

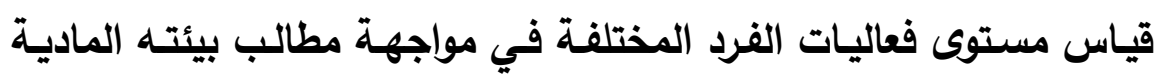
والطبيعية والسلوكية والاجتماعية. ويتكون المقياس من جزئين رئين فئيسيين،

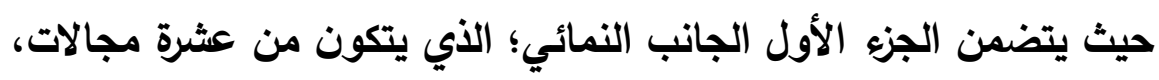

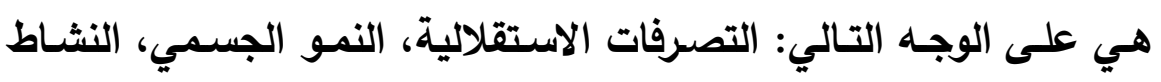

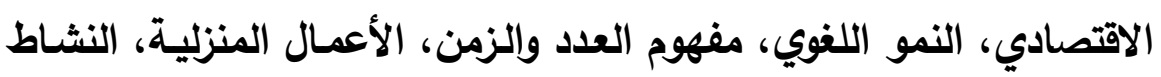

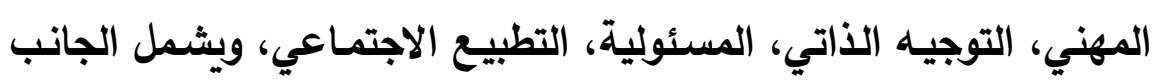

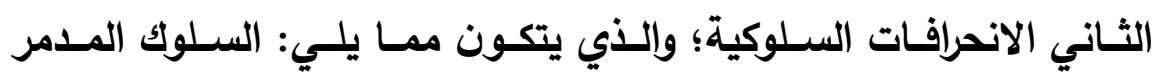

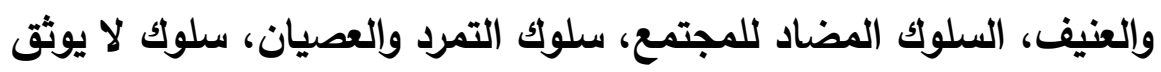

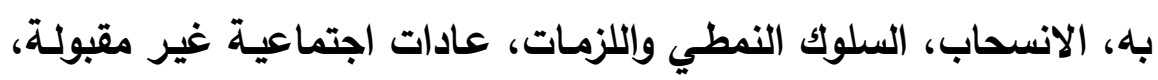

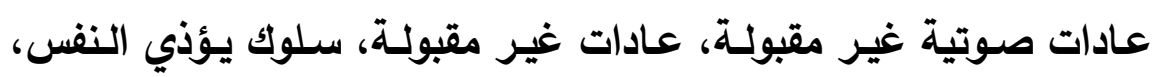

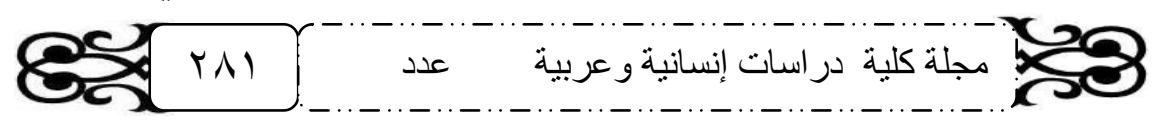




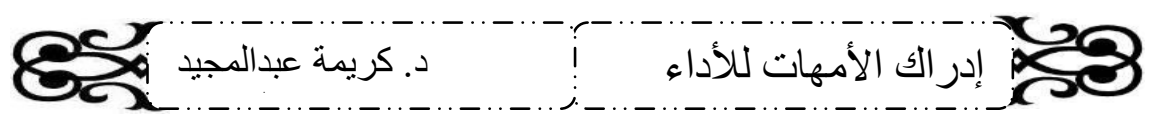

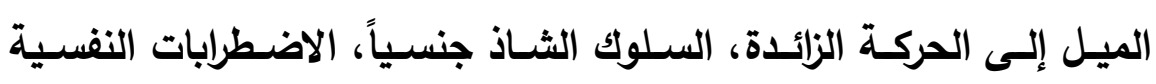
الانفعالية، استعمال الأدوية. وقد تناول البحث الراهن الجانب النمائي من مقياس السلوك التكيفي.

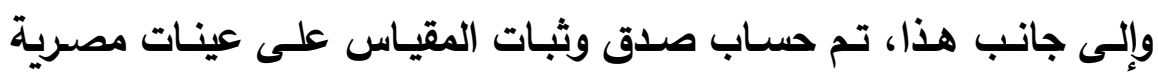

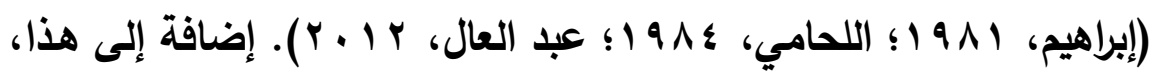

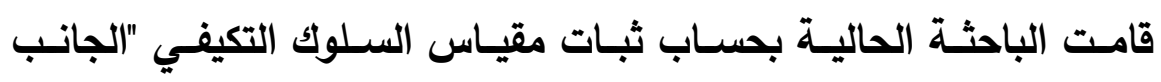

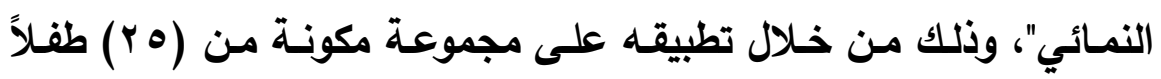
وطفلة من الأطفال ذي الإعاقة العقلية البسيطة بواسطة أمهاتهم باستخدام

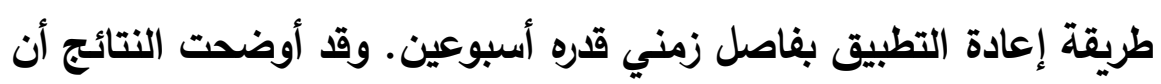

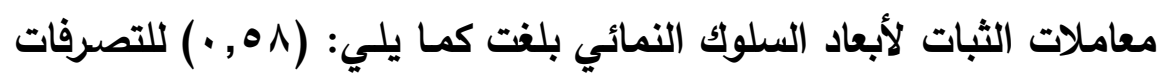

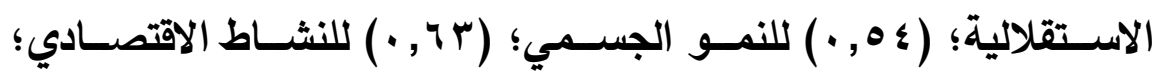

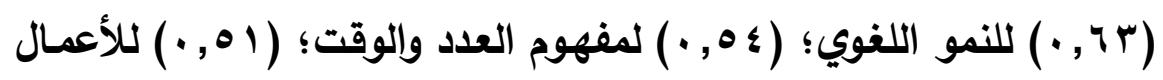

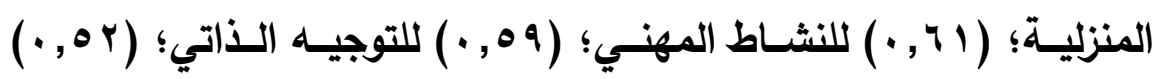

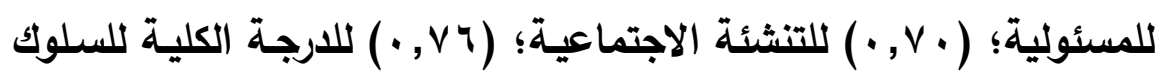
النمائي، وكلها معاملات مقبولة إحصائياً.

\section{إجراs|ت البمشث:}

تم تنفيذ البحث وفقاً للخطوات التالية:

-تـم حسـاب ثبـات مقيـاس الأداء الـوظيفي باسـتخدام معادلـة ألفــا

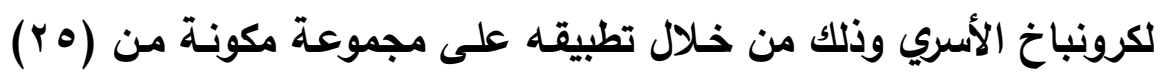

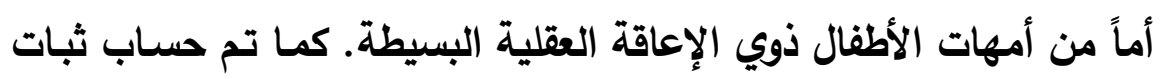

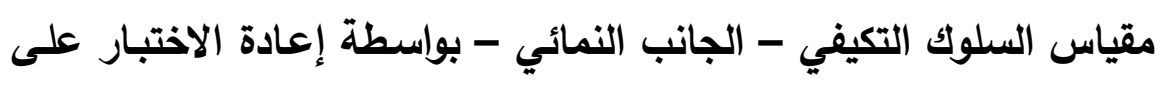

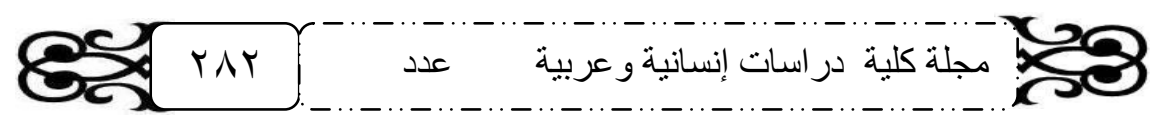


28 مجموعة مكونة من (ro) طفلاً من الأطفال ذوي الإعاقة العقلية البسيطة. -بعد التأكد من سلامة الخصائص السيكومترية لكل من مقياس الأداء الوظيفي الأسري، والسلوك التكيفي؛ تم تطبيق مقياس الأداء الوظيفي

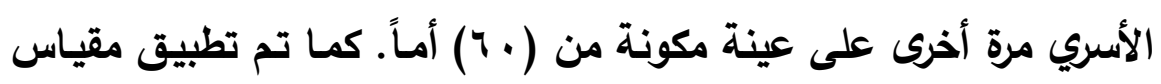
السلوك التكيفي على مجموعة مكونة من ستين طفلاً وطفلة (. آ طفلاً، و · ب طفلـة) من أطفال الروضـة ذوي الإعاقة العقلية البسيطة بواسطة أمهاتهم.

-تم تفريغ استجابات بنود المقياسين، وتفريغهما، لتحليلهما إحصائياً.

\section{الأساليب الإمصائية المستفدهة:}

تم استذام الأسلاليب الإحصائية التالية:

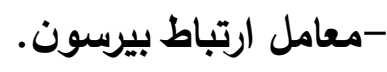
- معادلة ألفا لكرونباخ.

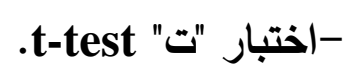

\section{نتائج البمث وتفسيرها:}

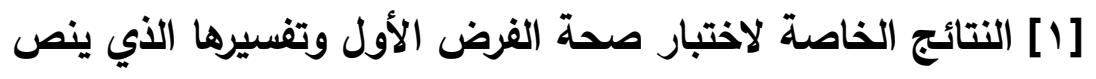

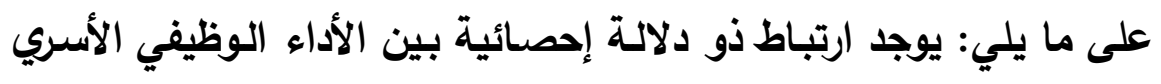

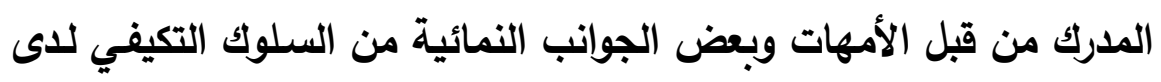
أبنائهن ذوي الإعاقة العقلية البسيطة. 
23

جدول (1)

ES 
28 إدراك الأمهات للأداء

أوضحت النتائج في جدول (1) وجود ارتباطات موجبة دالة إحصائياً

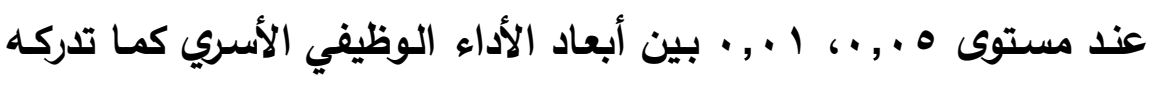

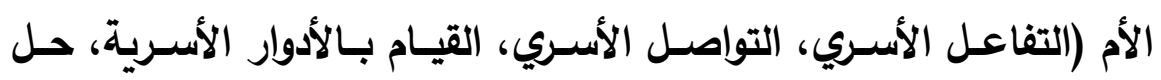

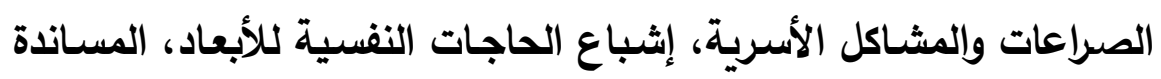

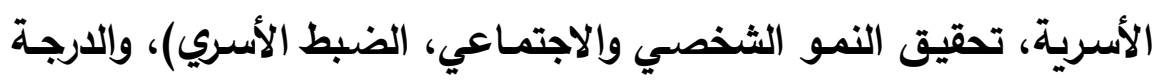

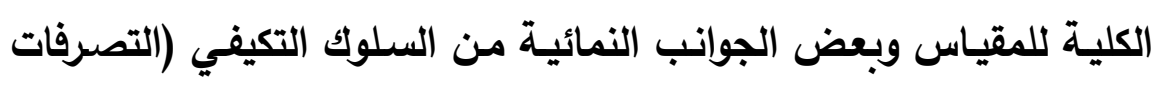

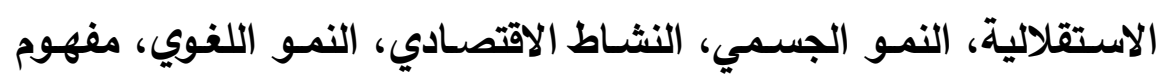

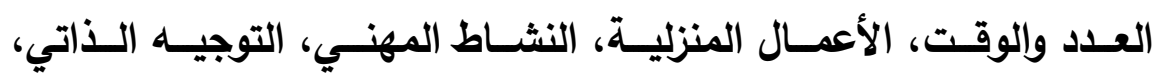

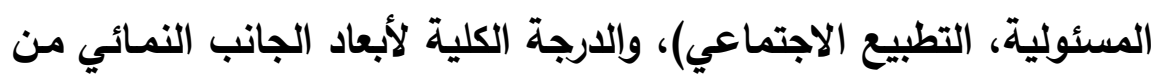

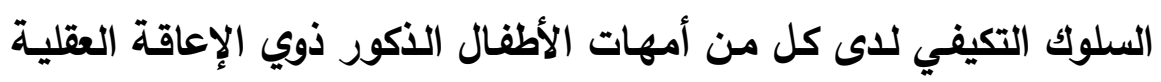

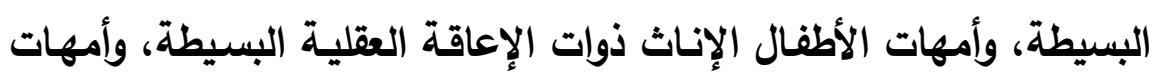

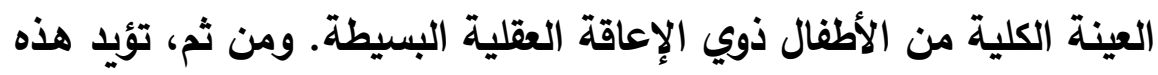

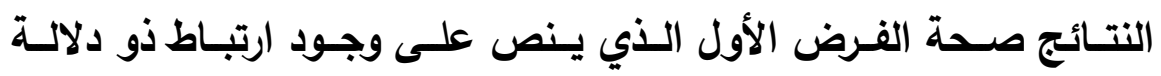

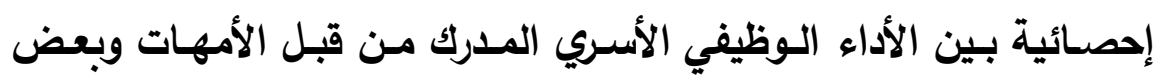

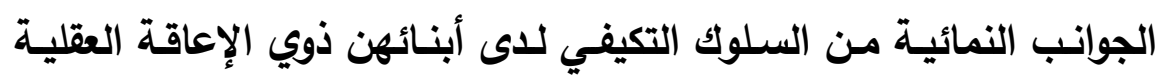
البسيطة.

وتتفق نتائج هذا الفرض عامـة مـا أنتهت إليه نتائج كل من البحوث التي تناولت الاتجاهات الوالدية والسلوك التكيفي للى الطفل المعاق

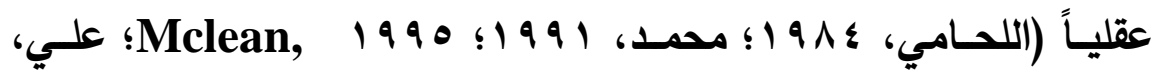

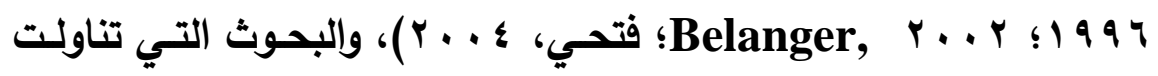
Semel, (المناخ الأسري والسلوك التكيفي لدى الطفل المعاق عقلياً

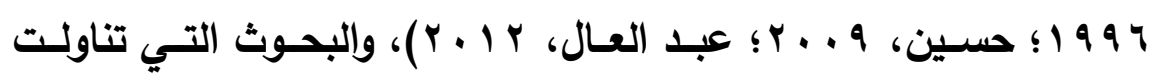

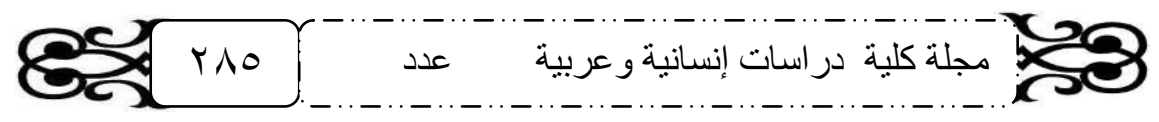




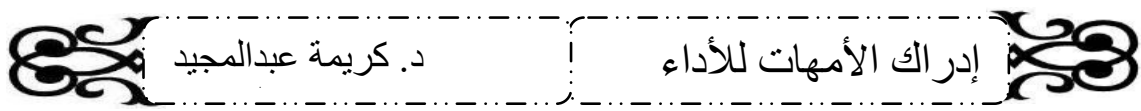

الأداء الوظيفي الأسري والسلوك التكيفي لاى الطفل المعاق عقلياً (Maclinton, 19 9v ؛Litt, 19 9v)

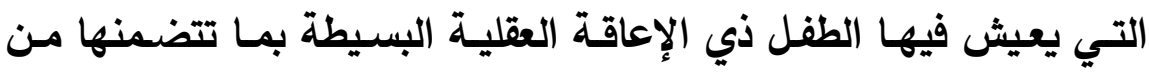

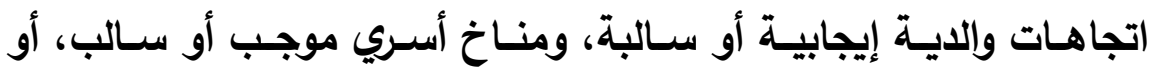

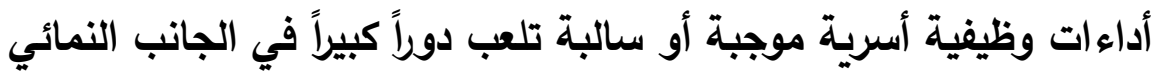
من السلوك التكيفي له بالإيجاب أو بالسلب.

ولا شك أنه عندما تكون الأداءات الوظيفية الأسرية موجبة، بمعنى أن

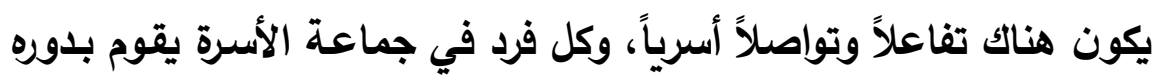

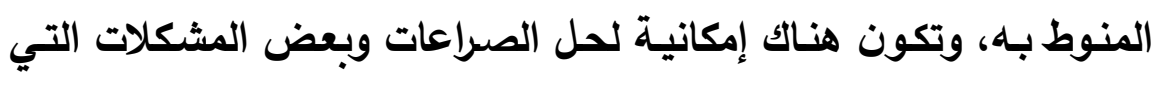

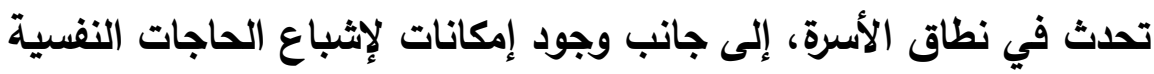

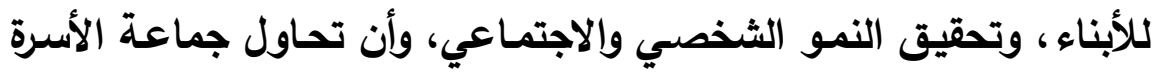

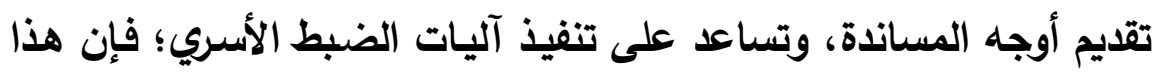

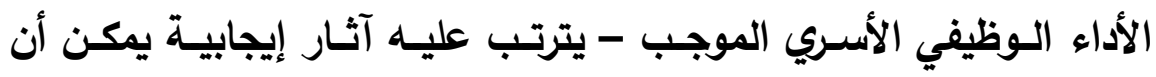

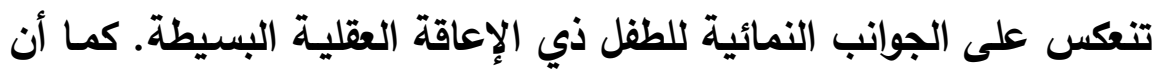

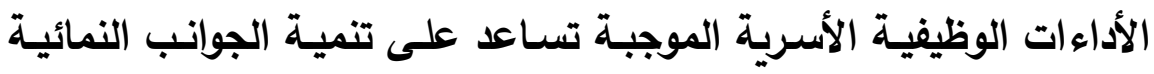

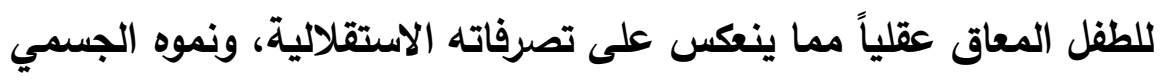
والاقتصادي واللغوي، ومفهومه عن العدد والوقت، وممارسة بعض الأعمال

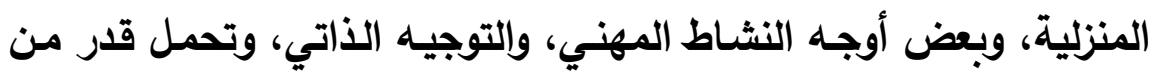
المسئولية، وتفهم استراتيجيات التطبيع الاجتماعي، والعكس صحيح.

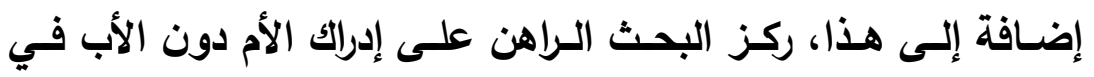

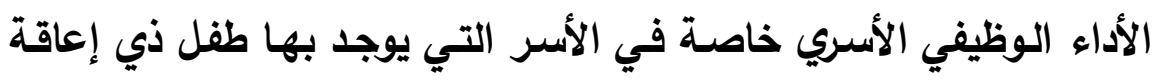

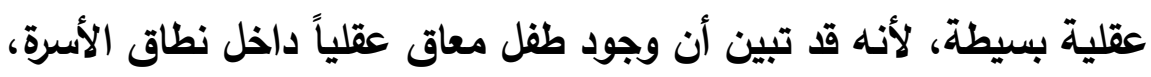

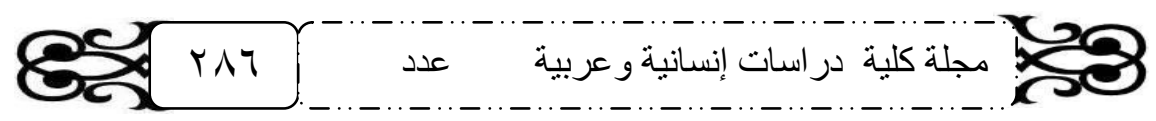




\section{ES 28}

فإن الذي يحمل عبء هذا في المقام الأول هي الأم، فهي التي تكون

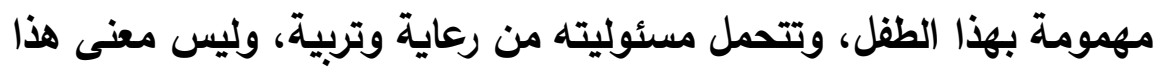
أن الأب ليس له دور في هذا الصدد، ولكن بالمقارنة نجد أن الأم هي التي وني

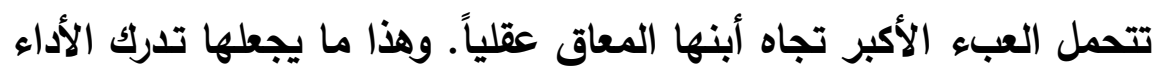

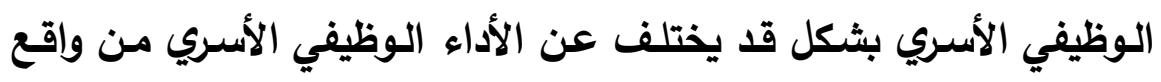

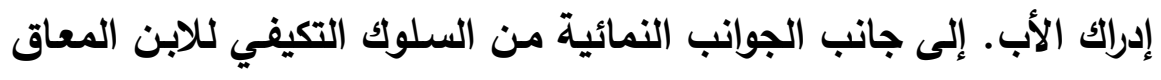

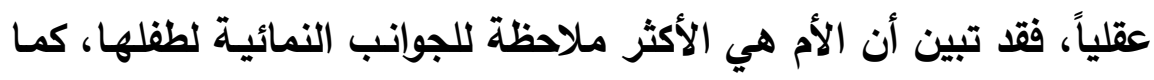

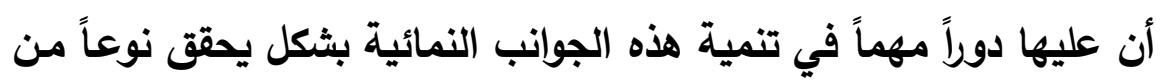
التكيف السلوكي للطفل ذي الإعاقة العقلية البسيطة.

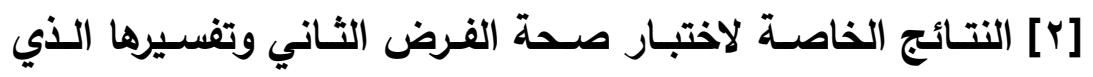
ينص على مـا يلـي: توجد فروق ذات دلالـة إحصـائية في أبعـاد الأداء

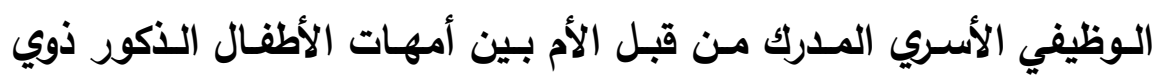

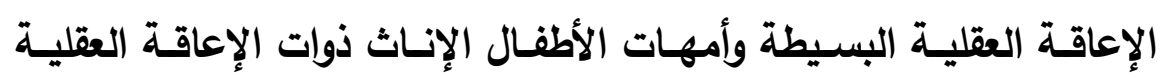

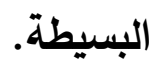


28 (إدراك الأمهات للأداء

$$
\text { جدول (r) }
$$

المتوسطات الحسابية والانحرافات المعيارية وقيم "ت"، ودلالتها الإحصائية

في الأداء الوظيفي الأسري المدرك من قبل الأم

بين أمهات الأطفال الذكور وأمهات الأطفال الإناث

من ذوي الإعاقة البسيطة

\begin{tabular}{|c|c|c|c|c|c|c|}
\hline الإحصائية & "تيم & الانحرافات & المتوسطات & العدد & مجموعات البحث & الألداء الوظيفي \\
\hline \multirow[t]{2}{*}{$\cdot, .0$} & \multirow[t]{2}{*}{$r, Y \leqslant$} & $\leq, 91$ & $r \wedge, r \leq$ & $\mu$. & أمهات أطفال & \multirow[t]{2}{*}{ التفاعل الأسري } \\
\hline & & 7,01 & $\varepsilon r, r_{0}$ & $r$. & أمهات أطفال إناث & \\
\hline \multirow[t]{2}{*}{$\cdot,+1$} & \multirow[t]{2}{*}{ Y,TV } & $\{, 11$ & $r v, \leqslant 0$ & $\mu$. & أمهات أطفال & \multirow[t]{2}{*}{ التواصل الأسري } \\
\hline & & $\varepsilon, r_{1}$ & צ & $r$. & أمهات أطفال إناث & \\
\hline \multirow{2}{*}{$\cdot, .0$} & \multirow{2}{*}{$r, r \wedge$} & $7,7 \vee$ & $r v, \wedge r$ & $\mu$. & أمهات أطفال & \multirow{2}{*}{ القيام بالأدوار } \\
\hline & & $\vee, 9 \wedge$ & $\leqslant r, \leqslant r$ & $r$. & أمهات أطفال إناث & \\
\hline \multirow{2}{*}{$\cdot, .0$} & \multirow{2}{*}{$r, r_{1}$} & $7, Y q$ & $r \wedge, v_{0}$ & $\mu$. & أمهات أطفال & \multirow{2}{*}{ حل الصراعات } \\
\hline & & $7, Y 7$ & $\varepsilon r, r q$ & $\mu$. & أمهات أطفال إناث & \\
\hline
\end{tabular}

S2 


\begin{tabular}{l|l|l|l|l|l|l|l|}
\hline \\
\hline
\end{tabular}

أشـارت النتائج في جدول (Y) إلى وجـود فروق دالـة إحصـائياً عند

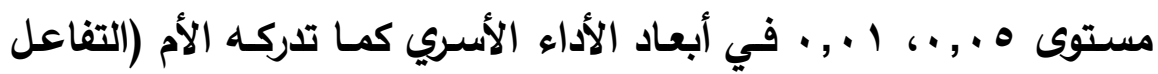
الأسري، التواصل الأسري، القيام بالأدوار الأسريـة، حل الصراعات والمشاكل هـاءله الأسرية، إثباع الحاجات النفسية للأبناء، المساندة الأسرية، تحقيق النمو الشخصـي والاجتمـاعي، الضـبط الأسـري)، واللدرجـة الكليـة للمقيـاس بين أمهات الأطفـال الـذكور ذوي الإعاقـة العقليـة البسـيطة، وأمهـات الأطفـال 
28

الإناث ذوات الإعاقة العقلية البسيطة. وتدعم هذه النتائج صحة اختبار

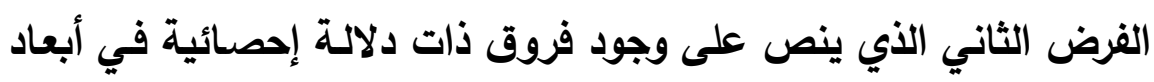

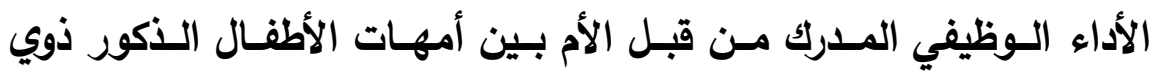

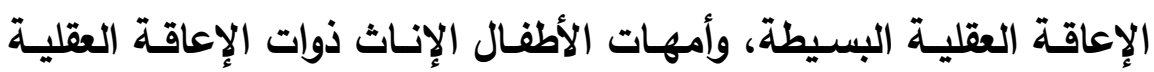

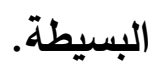

وقد أبانت نتائج الفرض الثاني أن أمهات الأطفال الإناث ذوات الإعاقة

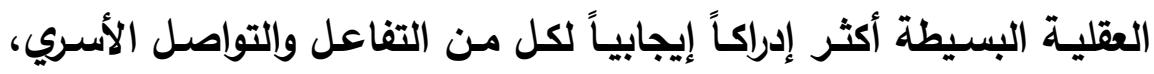

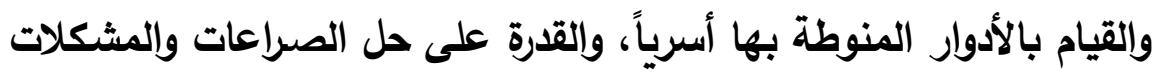

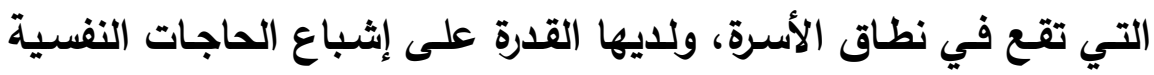

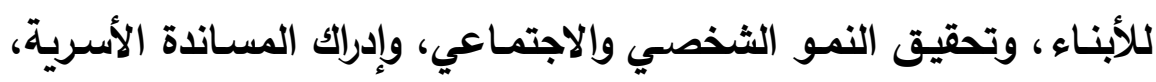

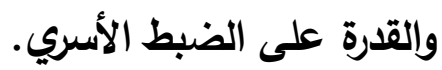

وعلى الرغم من عدم وجود بحوث سابقة في هذا الصدد للكثف عن

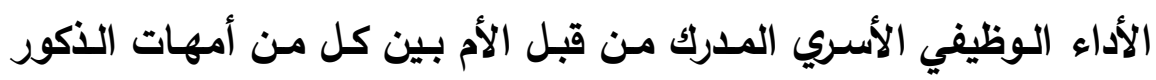

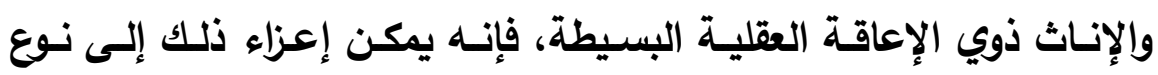

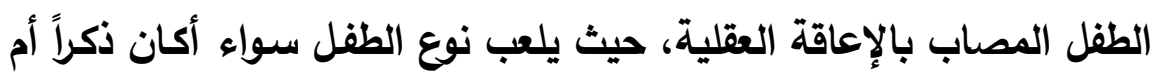

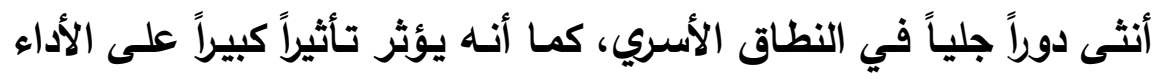

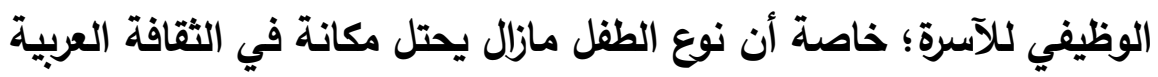

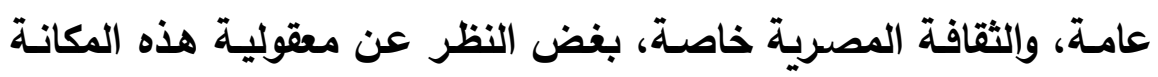

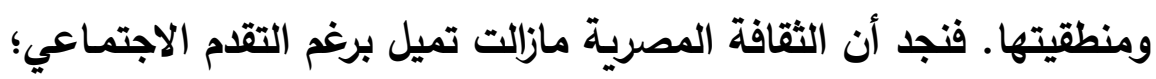

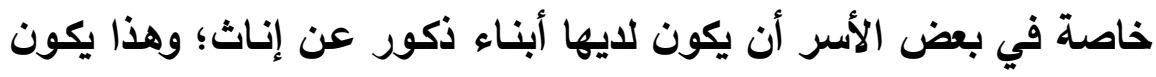

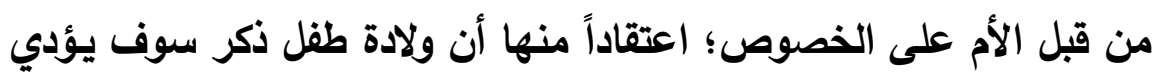

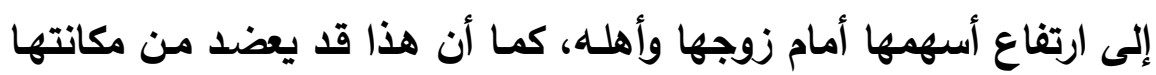

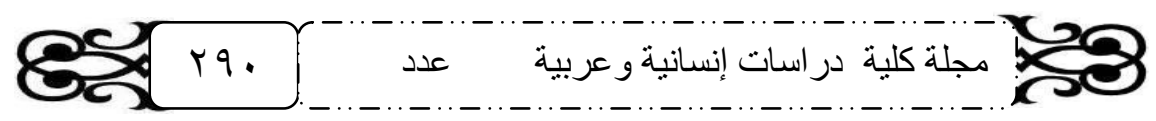




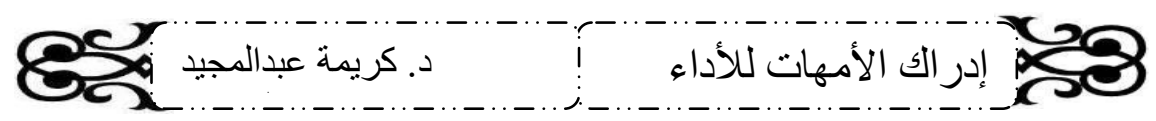

في منزل الزوجية، لذا فإن الأم قد تصاب بالهلع والكمد نتيجة ولادة طفل ذكر معاق عقلياً، وهذا ما يؤثر كثيراً على إدراكها للأداء الوظيفي الأسري. [ب] النتـائج الخاصـة لاختبار صحة الفرض الثالث وتفسيرها الذي

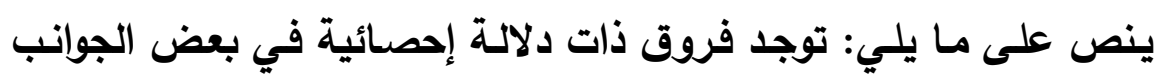

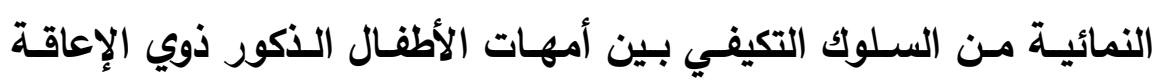
العقلية البسيطة وأمهات الأطفال الإناث ذوات الإعاقة العقلية البسيطة. 


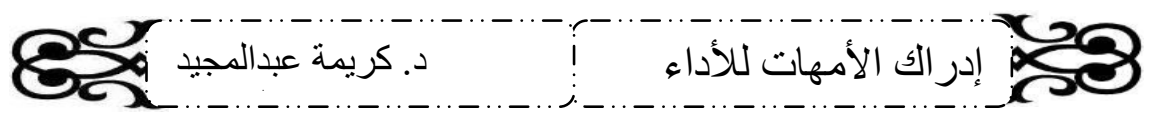

$$
\text { جدول (r) }
$$

المتوسطات الحسابية والانحرافات المعيارية وقيم "ت"،

ودلالتها الإحصائية في بعض الجوانب النمائية من السلوك التكيفي النمائي

بين الأطفال الأكور والأطفال الإناث من ذوي الإعاقة البسيطة

\begin{tabular}{|c|c|c|c|c|c|c|}
\hline الإحصائية & "تيم & الانحرافات المعياريـة & المتوسطات & العدد & مجموعات & جوانب السلوك \\
\hline \multirow[t]{2}{*}{$\cdot, \cdot 1$} & \multirow[t]{2}{*}{$0, Y \mu$} & qu & $\mu \Delta, r$. & $r$. & ذكور & \multirow{2}{*}{ الاستقرفاتلية } \\
\hline & & س & $r q, q$. & $r$. & أطفال إناث & \\
\hline \multirow[t]{2}{*}{., .1} & \multirow[t]{2}{*}{ r } & $r, \wedge q$ & $I r, v$. & $\mu$ & ذُكور & \multirow[t]{2}{*}{ لنمو الجسمي } \\
\hline & & $r, \wedge 0$ & $1 v, 1$. & $r$. & أطفال إناث & \\
\hline \multirow[t]{2}{*}{., .1} & \multirow[t]{2}{*}{$0, \ldots$} & $r, \mu v$ & $\Lambda, 9$. & $\mu$ & ذكور & \multirow{2}{*}{ الاقتصادي النشاط } \\
\hline & & $r, v \wedge$ & $1 \%, 7$. & $r$. & أطفال إناث & \\
\hline \multirow[t]{2}{*}{$\cdot, \cdot 1$} & \multirow[t]{2}{*}{$0, \ldots$} & & IV,r. & $\mu$ & ذكور & \multirow[t]{2}{*}{ النمو اللغوي } \\
\hline & & $r, i v$ & r I, T. & $r$. & أطفال إناث & \\
\hline$\cdot, \cdot 1$ & $\varepsilon, \cdot V$ & $r, r o$ & $1 \varepsilon, \mu$. & $\mu$. & ذكور & مفهوم العدد \\
\hline
\end{tabular}

مجلة كلية دراسات إنسانية وعربية 


\begin{tabular}{|c|c|c|c|c|c|c|}
\hline & & r, & $1 \wedge, \ldots$ & $r$. & أطفال إناث & \\
\hline \multirow[t]{2}{*}{$\cdot, \cdot 1$} & \multirow[t]{2}{*}{$\varepsilon, \cdot V$} & $r, r$ & $9, \wedge$. & r. & ذكور & \multirow{2}{*}{ الأعمال } \\
\hline & & $r, 1$. & $1 r, 1$. & $r$. & أطفال إناث & \\
\hline \multirow[t]{2}{*}{$\cdot,+1$} & \multirow[t]{2}{*}{$\Gamma, \neg \wedge$} & $r, 9$ & $\bullet, V$. & r. & ذكور & النش \\
\hline & & $r, V \varepsilon$ & $r, q$. & $r$. & أطفال إناث & \\
\hline \multirow[t]{2}{*}{$\cdot, \cdot 1$} & \multirow[t]{2}{*}{$\varepsilon, V_{1}$} & $r, r$. & $10,1$. & $\mu$. & ذكور & \multirow[t]{2}{*}{ التوجيه الذاتي } \\
\hline & & r, \&. & $19, r$. & r. & أطفال إناث & \\
\hline \multirow[t]{2}{*}{$\cdot,+1$} & \multirow[t]{2}{*}{$\Gamma, \wedge \varepsilon$} & r ז, & $r, r$. & r. & ذُكفال & \multirow[t]{2}{*}{ المسئولية } \\
\hline & & $r, q \leq$ & $7, \ldots$ & r. & أطفال إناث & \\
\hline \multirow[t]{2}{*}{., .1} & \multirow[t]{2}{*}{$0,1 r$} & $r, \Lambda$ & $1 \leqslant, \varepsilon$. & r. & ذكور & \multirow{2}{*}{ الاجتماعيع التطبيع } \\
\hline & & $r, i v$ & $1 \wedge, 7$. & $r$. & أطفال إناث & \\
\hline \multirow[t]{2}{*}{$\cdot, .1$} & \multirow[t]{2}{*}{$11, r$} & $1 \cdot, r_{1}$ & I rv, & r. & ذكور & \multirow[t]{2}{*}{ الارجة الكلية } \\
\hline & & 11,94 & $1 v \cdot, \ldots$ & r. & أطفال إناث & \\
\hline
\end{tabular}

أسفرت النتائج في جدول (ץ) عن وجود فروق ذات دلالة إحصائية عند مستوى 1 . , . في الجوانب النمائية من السلوك التكيفي (التصرفات 
28 إدراك الأمهات للأداء

الاستقلالية، النمـو الجسـي، النشـاط الاقتصـادي، النمـو اللغوي، مفهوم

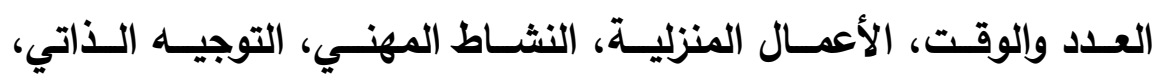

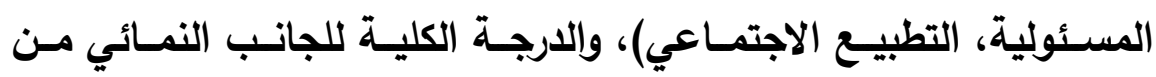
السلوك التكيفي بين كل من الأطفال الذكور والإناث ذوي الإعاقة العقلية الإنة

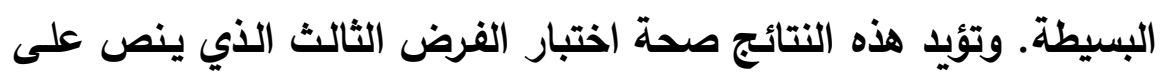

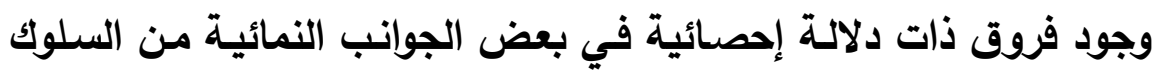

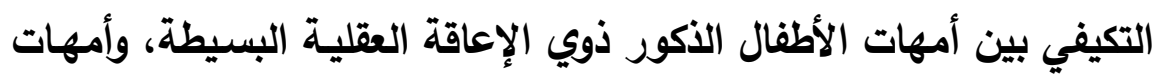
الأطفال الإناث ذوات الإعاقة العقلية البسيطة.

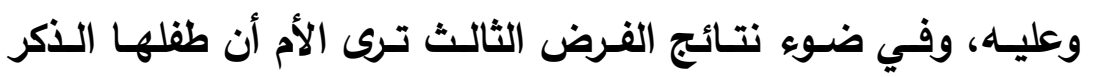

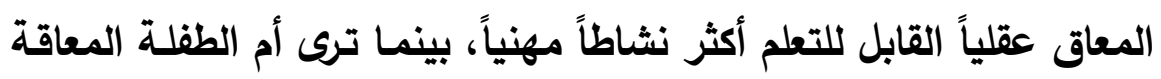

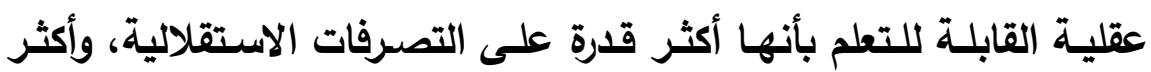

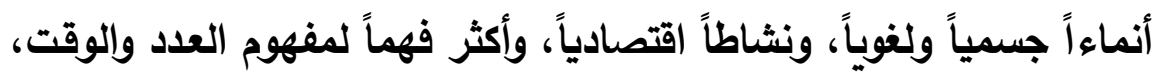

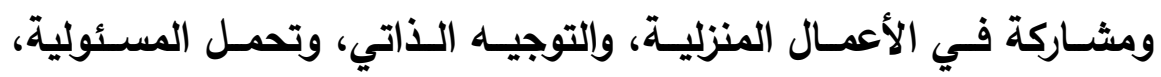
وتفهمهاً لآليات التنشئة الاجتماعية.

وربمـا يعزى هذا، على الرغم من عدم وجود بحوث سـابقة في هذا

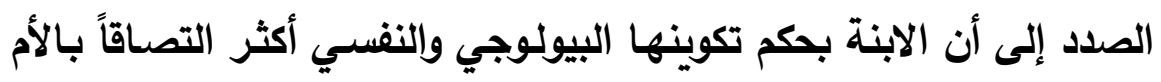

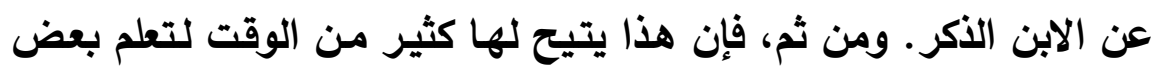

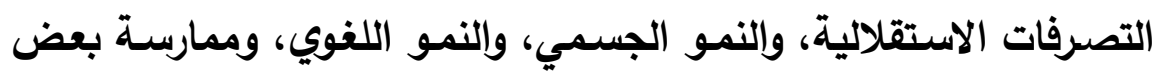

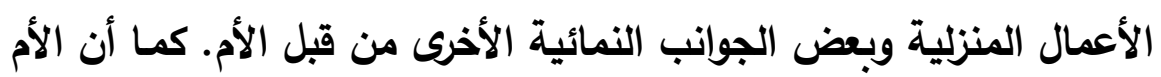

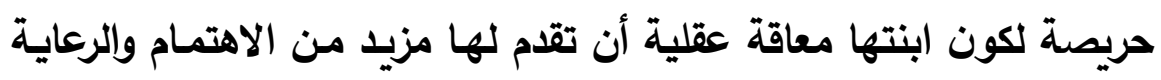

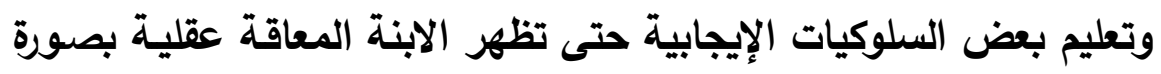

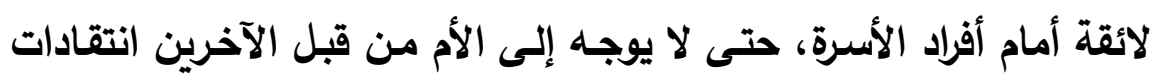

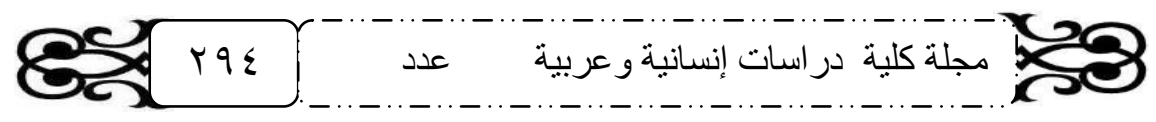




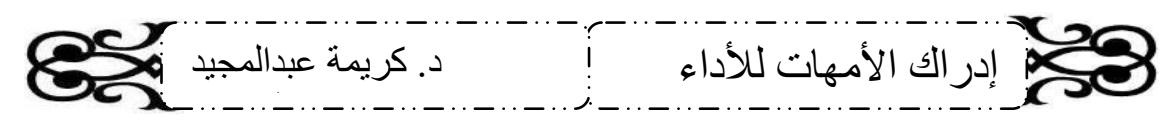

نحو إهمالها أو تركها لابنتها دون تعليم بعض الجوانب النمائية اللازمـة حتى تستطيع أن تحقق قدراً من السلوك التكيفي. تصني.

ومسن ثم، وفي ضوء مـا أنتهت إليهه نتائج البحث الحالي، فإن هذا المجال في حاجة إلى المزيد من البحوث؛ خاصـة التجريبية لتفعيل الأداء

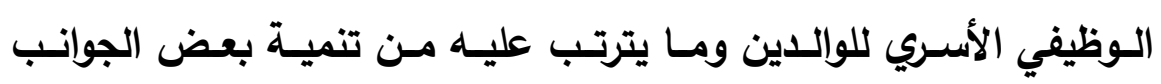
النمائية لأبنائهم ذوي الإعاقة العقلية البسيطة. 
28

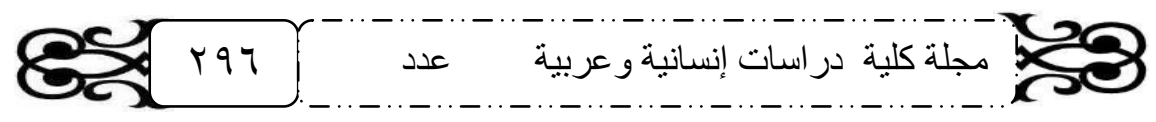




\section{8 \\ المراجع: - المجاج

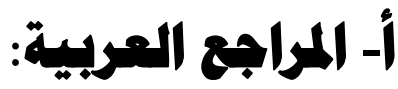

إبراهيم، عبد الرقيب أحمد (911) (911). دراسـة تحليليـة لبعض أنمـاط

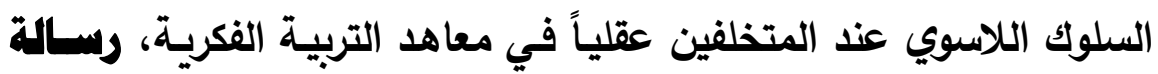
دكتوراه فير منشورة، كلية التربية، جامعة أسيوط.

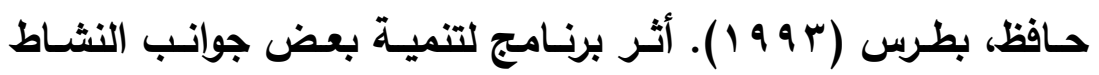

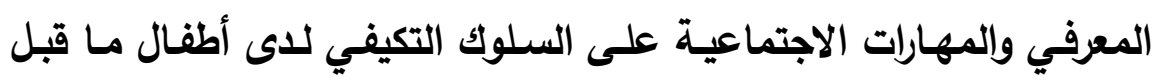

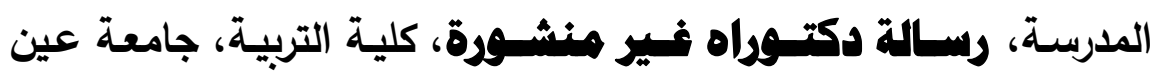
شمس.

حسيب، عبد المنعم عبد الله (ب99 19). مستوى مفهوم الذات والتوافق النفسي وعلاقتها بالسـلوك التأملي والاندفاعي لطلبـة المرحلـة الثانويـة:

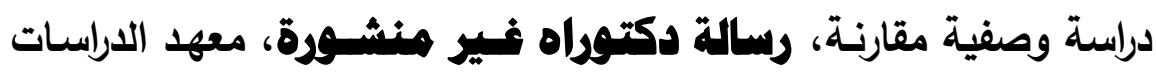
العليا للطفولة، جامعة عين شمس.

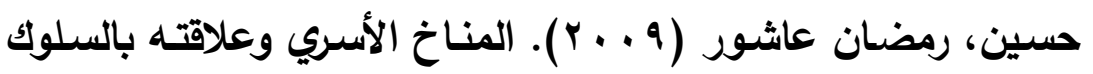

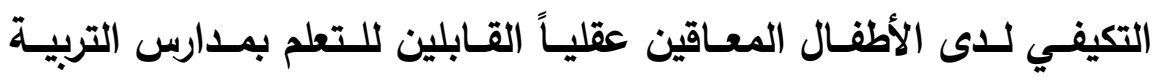
الفكرية، رسالة هاجستير غير منشهورة، كلية التربية، جامعة حلوان.

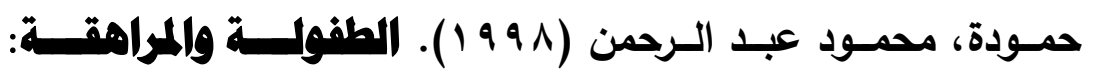
المشكلات النفسية والعلاج، الطبعة الثالثة، القاهرة: المطبعة التجارية. خلف الله، زينب عبد اللطيف (ب99 19). الإحساس بالوحدة النفسية

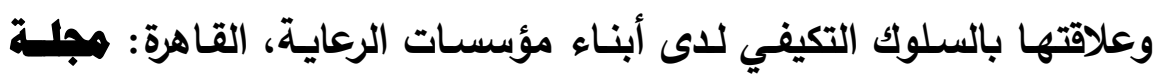
28 


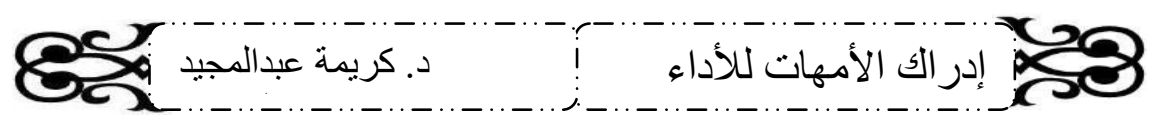

معوقات الطفولة، جامعة الأزهر.

درويش، رمضـان محمـود (919 19). أسـاليب المعاملـة الوالايـة كمـا

يــركها الابـن الوحيـــ والابـن متعـد الأخــوة وعلاقتهـا بـبعض متغيـرات

الثخصية، راسالة هاهستير فير منشهورة، كلية التربية، جامعة الأزهر.

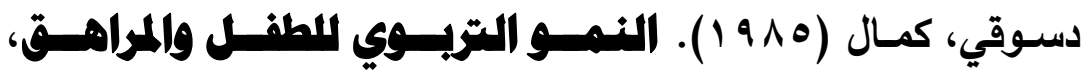

الزقازيق: مطابع جامعة الزقازيق.

الروسان، فاروق (ه . . ب). هقدمة في الإعاقة العقلية، عمان: دار

الفكر للطباعة والنشر والتوزيع.

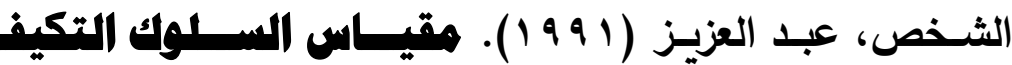

اللأطفال: المعايير الماصرية والسعودية، الطبعة الثانية، القاهرة: مكتبة الانجلو المصرية.

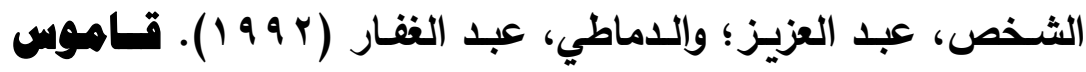

التربية الخاصة وتأهيل فير العاديين، القاهرة : مكتبة زهراء الثرق.

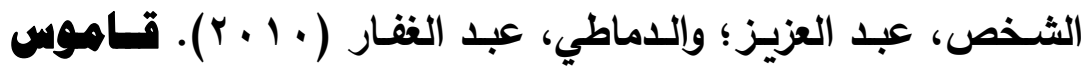

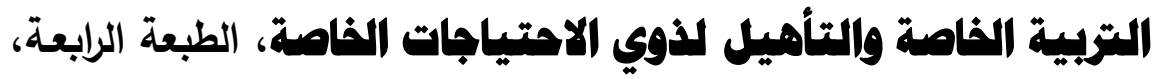
القاهرة : مكتبة الانجلو المصرية.

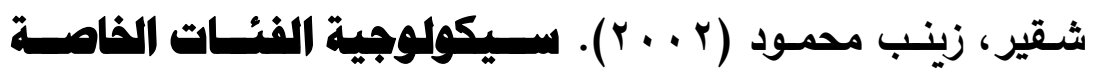
والامعوقين، القاهرة : مكتبة النهضة المصرية. الثناوي، محمد محروس (9 9 9 1). التفالف العقلي: الأسباب، التشفيص، البرامج، القاهرة: مكتبة غريب للطباعة والنشر.

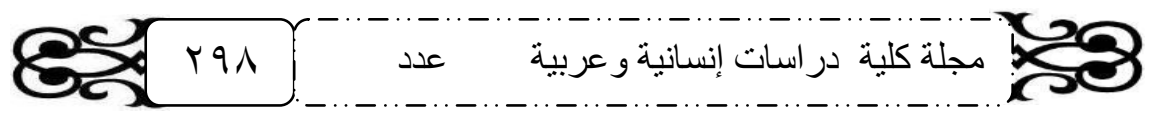


28

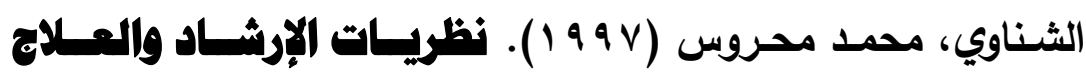

النفسي، القاهرة: دار غريب للطباعة والنشر.

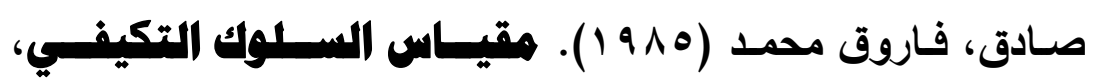

القاهرة: مكتبة الانجلو المصرية.

عاقل، فاخر (911 ). معبم العلـوم النفسية، لبنان: دار الرائد

العربي.

عبد السـلام، سميرة أبو الحسن (ع ـ . ؟). الأداء الوظيفي الأسري:

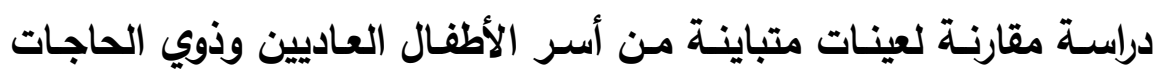

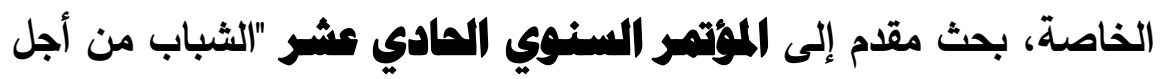

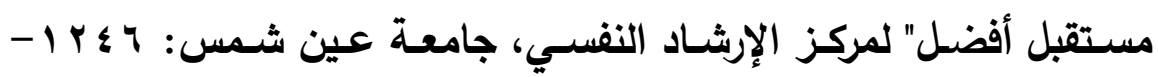
.1111

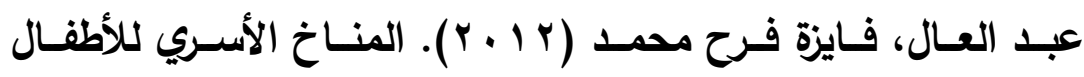
المعوقين عقلياً القابلين للتعلم وعلاقته بالسلوك التكيفي لديهم، راسيسالة ماجستير غير منشورة، معهد الدراسات التربوية، جامعة القاهرة. عبد المنعم، آمال محمود (999 99 ) ). فعالية برنامجج لخفض الضغوط

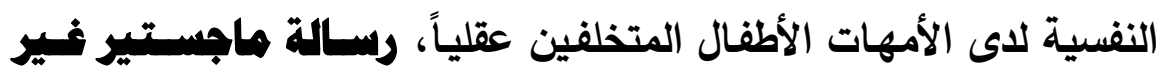
منشورة، كلية التربية، جامعة الزقازيق. عكاشة، أحمد (r99 (9)). الطب النفسي المعاصـر، القاهرة: مكتبة الانجلو المصرية. علي، ميادة محمد (19 99 1). الاتجاهـات الوالديـة وعلاقتها بالسلوك

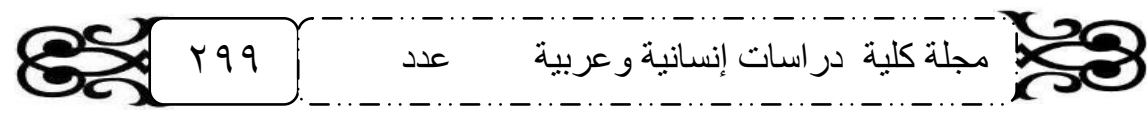




\section{8}

التكيفي للأطفال المتخلفين عقلياً والمصابين بأعراض الداون، ريسالة هاهستير فير منشسورة، معهد الدراسات العليا للطفولة، جامعة عين

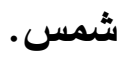

فتحي، نجلاء ( ( . . ب). الاتجاهاهت الوالدية وعلاقتها بالاضطرابات

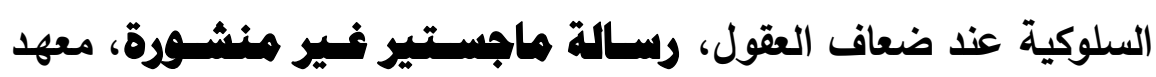
الدراسات العليا للطفولة، جامعة عين شمس.

فهـي، مصطفى (9^v (1). التكيــف النفسـي، القـاهرة: مكتبـة

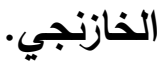

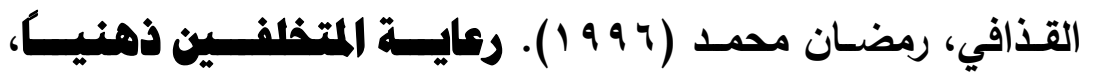
الإسكندرية: المكتب الجامعي الحديث.

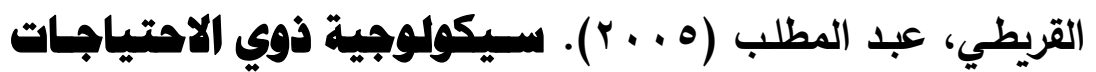
الخاصة وتربيتهم، الطبعة الرابعة، القاهرة: دار الفكر العربي. كامل، سهير؛ وسليمان، شحاته (ه . . ץ). سـيكمالوجية الأطفـال ذوي الاحتياجات الخاصة، الطبعة الثانية، الإسكندرية: مركز الإسكندرية

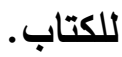

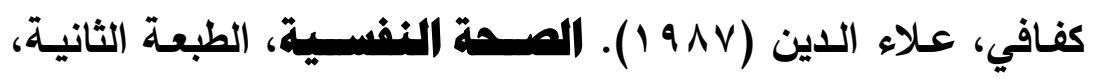
القاهرة: مكتبة الانجلو المصرية.

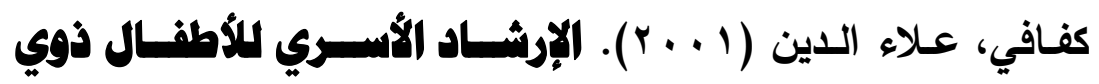
الحاجات الخاصة، القاهرة: دار قباء. اللحامي، نهى يوسف (ـ 9 (1). العلاقة بين الاتجاهات الوالاية نحو 28 


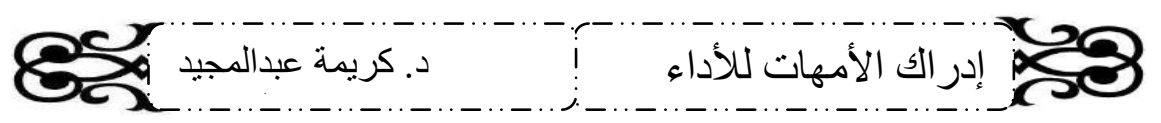

الإعاقـة العقليـة والعلاقات الأسـرية، والسـلوك التكيفي لمراهقـات متخلفـات عقلياً، رسالة دكتوراه فير منشهرة، كلية الاراسـات الإنسانية، جامعة

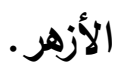

محروس، وفاء (r . r). الضغوط النفسية الأسرية والسلوك التوافقي لطفل الروضة الكفيف، ولسالة ماجسـتير فـير منشـورة، كلية التربية،

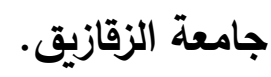
محمد، أشرف صبره (199 19). اتجاه الآباء نحو أبنائهم المتخلفين عقلياً وعلاقة تلك الاتجاهات بسلوك أبنائهم التكيفي بمدينة أسيوط، رسـالة ماجستير غير منشورة، كلية التربية، جامعة أسيوط.

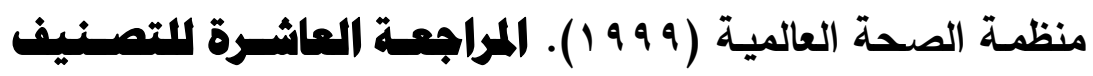

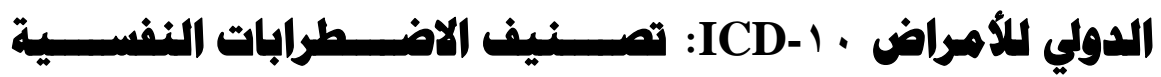
السلوكية (أشرف على الترجمة: أحمد عكاشـة)، الإســندرية: المكتب الإقليمي لثرق البحث المتوسط. الهابط، محمد السيد (9 9 1 ). التكيف والممة النفسية، الطبعة الثانية، الإسكندرية: المكتب الجامعي. 
Belanger, S. (r... r). The advisability of Kinship Foster placements: A comparison of adaptive behaviors and psychopathology of children in traditional and Kinship Foster Care, Dissertation Abstracats, $7 Y(1)$ : $r_{1} .0$.

Caqelka, P. \& Preham, H. (1911). A Mental retardation from categories to people, Columbus: Ohio Memill.

Coan, R. (19^ץ). Psychology of Adjustment, New York: John Wiley and Sons.

Henley, M.; Ramsey, R. \& Algzzine, R. (1994). Characteristics and strategies for teaching students with mild disabilities, London: Allys Bacon, Inc.

Jonson, E. (199^). The effect of family functioning and family sense of competence on people with mental illness. Journal of Applied Family Studies, $\varepsilon V(\varepsilon): \varepsilon \varepsilon r-\varepsilon 01$.

Litt, E. ( $99 \mathrm{~V})$. Development of individual different in mentally retarded child: A psycho - dynamic perspective adaptive behavior, Dissertation Abstracts, $0 \wedge$.

Maclinton, J. (199V). The effects of the parenting alliance on children's adjustment, Dissertation Abstracts,

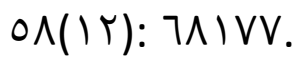

Mclean, S. (1990). The effects of a family training on the development of persons with mental retardation, Dissertation Abstracts, $07(.9): 0107$.

Morris, C. (19^Y). Introduction of Psychology, New York: Prentice - Hall, Inc.

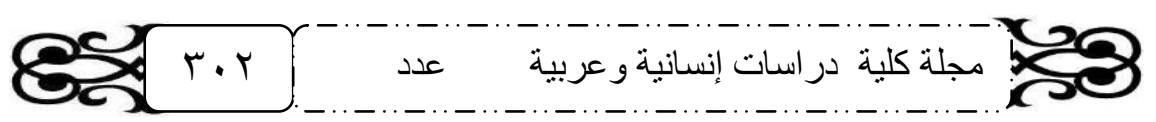




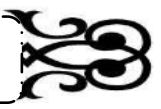

Petrson, R. \& Green, S. (1999). Family Roles, Washington: Josses - Bass publishers.

Semel, M. (1997). Evidence for child effects in the prediction of parent stress in families with mentally retarded child: The role of family life cycle, Dissertation Abstracts, 07(.9): 0107.

Siu, A. $(r \cdot r)$. Interpersonal competence, family functioning and parent - adolescent conflicts. Dissertation Abstracts International, $7 \pi(1 \cdot A):$

Smith, D. \& Tyler, N. (Y.l.). Introduction to Special Education: Making a Difference, $\mathrm{V}^{\text {th }}$ edition, New York: Merrill.

Wolman, B. (19/9). Dictionary of Behavioral Sciences. Saint Diego: Academic Press, Inc. 

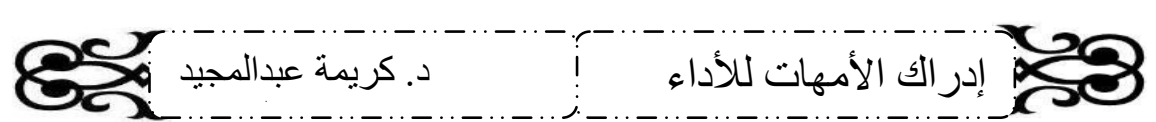

\title{
The Functional Family Performance
}

\author{
and its Relationship with Some
}

The Perception of Mothers for Developmental

Aspects for their Educable

\section{Mental Retarded Children in Kindergarten}

Abstract: The aim of this study is to explore the functional family performance as perceived by mothers and its relationship with some developmental aspects of adapative behavior for their educable mental retarded children in Kindergarten. The concepts of research study as the following: mental retardation, functional family performance, and adapative behavior are presented. Further, the previous research studies are presented. The hypotheses of the research study are as the following: (1) there is significant correlation between functional family performance as perceived by the mothers and some developmental aspects for their children who educable mental retarded, $(Y)$ there are significant differences in functional family performance dimensions as perceived by the mother between educable mental retarded male children mothers and educable mental retarded female children mothers, $(r)$ there is significant differences in some developmental aspects between educable mental retarded male children mothers and educable mental retarded female children mothers. The sample consists of $(r \cdot)$ mother of educable mental retarded male children and $(r \cdot)$ mother of educable mental female children. The ages mean of the mothers is $(\varepsilon \cdot, 7) \mathrm{Yrs})$ and at the ages mean of the educable

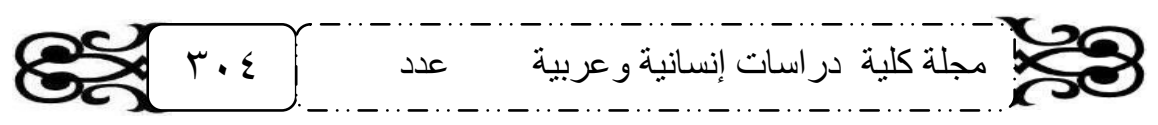


mental children is $(\varepsilon, 9$ ।Yrs $)$. Further more, Functional Family Performance Scale is consisted of the following: family interaction, family communication, family roles, family problems and conflicts solving, psychological needs for children, family support, social and personal development, family control and Developmental Aspects of Adapative Behavior Scale is consisted of the following: independence behaviors, psychical development, economic activity, language development, the concept of number and time, home works, vocational activity, self - orientation responsibility and socialization are used and its reliability are computed. The results indicated that there are positive statistical significant correlations between functional family performance as perceived by mother and some developmental aspects of adaptive behavior. As well as, there are statistical significant differences in functional family performance dimensions as perceived by the mother. Additionally, there are statistical significant differences in some developmental aspects of adaptive behavior between the mothers of educable mental retarded male children and the mothers of educable mental retarded female children. The results are interpreted according to the previous research studies. Some suggestions and future research studies are required. 
28

S2 